\title{
LA TEMPORALIDAD
} LINGÜÍSTICA EN ESPAÑOL

El presente documento de trabajo ha sido incluido dentro de nuestro repositorio institucional como Apropiación social de conocimiento por solicitud del autor, con nes informativos, educativos o académicos. Asimismo, los argumentos, datos y análisis incluidos en el texto son responsabilidad absoluta del autor y no representan la opinión del Fondo Editorial o de la Universidad.

\section{DISCLAIMER}

This coursework paper has been uploaded to our institutional repository as Social Appropriation of Knowledge due to the request of the author. This document should be used for informational, educational or academic purposes only. Arguments, data and analysis included in this document represent authors' opinion not the Press or the University.

Manuel Medardo Montero-Cádiz

Universidad Cooperativa de Colombia

Sede Bucaramanga 


\section{Acerca del autor}

Manuel Medardo Montero-Cádiz, doctor en Ciencias Lingüísticas, máster en Educación, profesor de la Facultad de Educación, Universidad Cooperativa de Colombia, sede Bucaramanga, Colombia.

Correo-e: manuel.monteroc@campusucc.edu.co

CvLAC: http://scienti.colciencias.gov.co:8081/cvlac/visualizador/generarCurriculoCv.do?cod_rh=0001631076

ORCID: https://orcid.org/0000-0001-5149-1338

GrupLAC: https://scienti.colciencias.gov.co/gruplac/jsp/ visualiza/visualizagr.jsp?nro=00000000008364

\section{Cómo citar este documento}

Montero-Cádiz, M. M. (2019). La temporalidad lingüística en español. (Documento de Generación de contenidos impresos N. ${ }^{\circ}$ 5). Bogotá: Ediciones Universidad Cooperativa de Colombia. doi: https://doi.org/10.16925/gcnc.08

Este documento puede ser consultado, descargado o reproducido desde nuestro repositorio institucional (http://repository.ucc. edu.co/handle/20.500.12494/7369) para uso de sus contenidos, bajo la licencia de Creative Commons Reconocimiento-No Comercial-Sin Obra Derivada 4.0 Internacional. http://creativecommons.org/licenses/by-nc-nd/4.0/

(c) (1) $(9)$ 


\section{TABLA DE CONTENIDO}

Introducción 7

Bello, precursor de las teorías contemporáneas sobre temporalidad lingüística y tiempo verbal 8

$\begin{array}{ll}\text { El sistema temporal de Reichenbach } & 10\end{array}$

$\begin{array}{ll}\text { Lamíquiz: la actualidad } & 15\end{array}$

Ángel López García: temporalidad, coherencia temporal

$\begin{array}{ll}\text { y actitud temporal } & 19\end{array}$

Luquet: los tiempos y los modos $\quad 31$

Havu: la constitución temporal del sintagma verbal 38

Propuesta de Havu $\quad 45$

Propuesta de instrumentos de análisis temporal que emplea Havu 46

Rojo y Veiga: temporalidad y tiempos verbales en español 50

Resumen de usos rectos y usos dislocados, según Rojo 59

La Nueva gramática de la lengua española 67

$\begin{array}{ll}\text { Conclusiones } & 71\end{array}$

$\begin{array}{ll}\text { Referencias } & 73\end{array}$ 


\section{INDICE DE FIGURAS}

Figura 1. Representación del antepospretérito 12

Figura 2. Funcionamiento de la época 18

Figura 3. Sistema del español 23

Figura 4. Transformación del Yo 24

Figura 5. El pasado 24

Figura 6. El copretérito $\quad 25$

Figura 7. El pospretérito 26

Figura 9. El procedimiento a para especificar la distancia 28

Figura 10. Los índices secundarios 28

Figura 11. El procedimiento $b \quad 29$

Figura 12. Imagen visual de más de un pasado y más de un futuro 29

Figura 13. Funcionamiento de los tiempos simples 30

Figura 14. Funcionamiento de los tiempos simples $\quad 30$

Figura 15. Pretérito y futuro $\quad 30$

Figura 16. Parámetros del sistema 31

Figura 17. Representación del tiempo 33

Figura 18. Representación del gerundio 33

Figura 19. Representación del infinitivo 33

Figura 20. Representación del participio 34

Figura 21. Manera de objetivar el universo temporal en español 34

Figura 22. El presente inactualizado 35

Figura 23. Presente futuro 35

Figura 24. Representación sin límite $\quad 35$

Figura 25. Tiempo físico (Rojo y Veiga, 1999) 51

Figura 26. Tiempo cronológico 51

Figura 27. Tiempo lingüístico 52

Figura 28. Esquema de la distribución de las formas teniendo en
cuenta la relación temporal primaria y el punto de referencia

Figura 29. Esquema del modo subjuntivo 57 


\section{ÍNDICE DE TABLAS}

$\begin{array}{ll}\text { Tabla 1. Subsistemas temporales } & 10\end{array}$

Tabla 2. Inventario de tiempos verbales 11

Tabla 3. Resumen de los subsistemas temporales del español aplicando la teoría de Reichenbach 14

Tabla 4. Sistema verbal del español 19

Tabla 5. Caracterización temporal 21

Tabla 6. Propuesta de Rojo $\quad 21$

Tabla 7. Propuesta de Lamíquiz 22

Tabla 8. Valores de la coherencia temporal 22

Tabla 9. Paradigma morfológico del presente es español 23

Tabla 10. Tiempos simples $\quad 45$

Tabla 11. Tiempos compuestos $\quad 45$

Tabla 12. Distribución de las formas teniendo en cuenta la relación temporal primaria y el punto de referencia 55

Tabla 13. Modo subjuntivo 56

Tabla 14. Denominaciones de los tiempos verbales 69 


\section{LA TEMPORALIDAD LINGÜÍSTICA
EN ESPAÑOL}

Manuel Medardo Montero-Cádiz

\section{RESUMEN}

En gramática española, uno de los temas más estudiados y polémicos es el sistema verbal del español. El presente trabajo tiene como propósito acercar a los estudiantes a diversas teorías sobre la temporalidad lingüística en español, desde Andrés Bello hasta autores contemporáneos como Reichenbach, Lamíquiz, Ángel López García, Gilles Luquet, Jukka Havu, Rojo y Veiga y la Nueva gramática de la lengua española. Asimismo, se establecen los puntos comunes que se derivan del análisis de dichas teorías, como la existencia de un punto de origen, o momento del habla, o de la enunciación, a partir el cual se orientan los tiempos verbales; que los tiempos verbales expresan anterioridad, simultaneidad o posterioridad respecto al momento del habla o en relación con otra referencia, que pueden expresar usos temporales básicos y usos modales derivados, y que existen valores aspectuales, ya sea expresados por la semántica del verbo, los morfemas flexivos o por las perífrasis verbales, que tienen una estrecha relación con los valores temporales que portan.

Palabras clave: anterioridad, momento del habla, posterioridad, simultaneidad, sistema verbal del español, temporalidad lingüística 


\section{Introducción}

En gramática española, uno de los temas más estudiados y polémicos es el sistema verbal del español. En este material se ofrecen diferentes concepciones teóricas, sin pretender recorrer o abordar todos los puntos de vista. Se parte de Andrés Bello, quien marcó un nuevo hito en esos estudios. Seguidamente se presenta a Reichenbach, cuyo análisis de la temporalidad incluye importantes aportes, por ejemplo, un esquema para limitar el número de tiempos que pueden darse en las lenguas naturales y dejar abierta la posibilidad de establecer un paralelismo estricto entre información morfológica y significado de los tiempos, lo que puede ser tomado como punto de partida para su representación sintáctica.

Lamíquiz (1982) fundamenta la primacía del tiempo verbal en el sistema verbal español. Su teoría contiene una importante fundamentación sobre los niveles de actualidad/inactualidad que se manifiestan en los tiempos verbales y el modo. Tal dicotomía se reitera en el epígrafe dedicado a la temporalidad, la coherencia temporal y la actitud temporal, según Ángel López García; en esta, el autor sustenta que la interpretación de los tiempos verbales en español puede hacerse desde las tres aristas: la temporalidad, la coherencia temporal o la actualidad.

Gilles Luquet (2004) efectúa un análisis de la relación entre modo y tiempo en el sistema verbal del español y, como otros autores, otorga una jerarquía superior al tiempo entre las demás categorías presentes en este sistema.

Jukka Havu (1998) ofrece un interesante análisis de la constitución temporal del sistema verbal en español, que permite delimitar los valores aspectuales de los temporales que se dan en los predicados.
Rojo y Veiga (1999) otorgan primacía al tiempo verbal y consideran el aspecto como una categoría subordinada a este. Para ellos los tiempos verbales son un sistema en el que se pueden describir coherentemente todos los usos: explican los que ellos llaman usos rectos y usos dislocados. Así, se asumen en este documento la teoría que ambos sustentan.

Por último, se hace referencia a la Nueva gramática de la lengua española, que se ha acercado a las teorías lingüísticas más actuales, sin desconocer la tradición, y ofrece un amplio estudio de las categorías de tiempo y aspecto en español.

Manuel Rivas Zancarrón (1998) señala que:

No hay gramática sobre este mundo o estudio publicado en cualquier revista o libro que no comience un apartado sobre el aspecto verbal afirmando cuán difícil y confusa se manifiesta esta categoría. Y es que el panorama es realmente preocupante si echamos una ojeada a la historia del fenómeno. (p. 273)

A lo anterior añade que los primeros estudios que se encuentran sobre el aspecto se muestran como intentos de definir ciertos fenómenos que no encuentran explicación adecuada en el seno de la categoría de tiempo y, sobre todo, en la comparación del verbo griego y el eslavo. Ya gramáticos griegos y latinos, así como checos de los siglos XVI y XVII, se habían percatado de que en su sistema verbal no todo se explicaba por formas temporales.

Rivas (2000) señala:

Ni qué decir tiene que ni esas apreciaciones subjetivas deben ser analizadas dentro de la categoría temporal, ni ha de abusarse de la aspectual para explicar todo aquello que no exprese tiempo en el verbo y afecte 
a la consideración subjetiva en el curso de un evento. Puede ocurrir, y de hecho ocurre, que esas realizaciones pretendidamente aspectuales no sean más que efluvios designativos que surgen de contemplar los diferentes contextos en los que una acción verbal aparece ubicada. Quiere decir esto que porque una lengua exprese contenidos de aspecto a través del contexto, no por ello ha de calificársela como aspectual. Este honor ha de reservarse para aquellas que, fuera de las realizaciones individuales concretas, mantienen en su sistema una relación opositiva formal. Está claro, pues, que todas las lenguas pueden desarrollar aspecto desde el punto de vista lógico o designativo. Pero no todas lo tienen formalizado corno estructura intralingüística. (p. 188)

Explica el autor que, desde esta perspectiva, la mayor parte de los gramáticos ven aspecto donde no hay más que desarrollos conceptuales subjetivos, frutos de la designación o de la contemplación de hechos particulares.

En los estudios acerca de los tiempos verbales de las lenguas románicas conviven tres puntos de vista radicalmente diferentes, según Pérez Saldanya (2004): el punto de vista más tradicional, según el cual el tiempo y el aspecto son categorías complementarias. Desde esta perspectiva, el aspecto permite introducir distinción entre tiempos verbales que coinciden respecto a la localización temporal (al tiempo gramatical). Un punto de vista no tan generalizado, defendido por Bello, parte de la idea de que el aspecto no es una categoría pertinente en las lenguas románicas y de que los tiempos verbales se pueden caracterizar exclusivamente por el tiempo gramatical. Esta postura la siguen Rojo y Veiga (1999). Un punto de vista minoritario se sitúa a medio camino y postula que las formas simples pueden ser caracterizadas a partir de oposiciones temporales (anterioridad, posterioridad y simultaneidad), pero que entre las formas simples y las compuestas se establecen oposiciones aspectuales, o de perspectiva, según la terminología de Coseriu y de sus seguidores.

\section{Bello, precursor de las} teorías contemporáneas sobre temporalidad lingüística y tiempo verbal

La Gramática de la lengua castellana de Andrés Bello es, además de una joya histórica de Hispanoamérica, una gramática normativa y una teoría del idioma. En el prólogo de la obra el autor declaró que era una guía para el uso; pero puede considerarse también como una teoría. Bello proclamó que cada lengua tiene su teoría particular — la gramática — frente a la idea de una estructura universal del lenguaje.

La originalidad de la obra radica en la elaboración que da a materiales antiguos y en la interpretación definitiva de muchos fenómenos gramaticales en el español. Entre otras razones, su grandeza está en que usó las únicas fuentes que le brindaba la tradición.

En la Gramática se encuentran fuertemente marcados los postulados que han sido el eje principal sobre el que ha girado la ciencia del lenguaje en el siglo xx y lo que va del xxi.

Amado Alonso, en su Introducción a los estudios gramaticales de Andrés Bello (1995)릴 modernidad y originalidad del pensamiento gramatical de Bello y marcó algunos puntos importantes para el buen conocimiento del tema. El estudio de Amado Alonso se centra fundamentalmente en la doctrina verbal de Bello.

1 Publicado en el volumen IV de las Obras Completas de Bello, Caracas, 1951. 
Como aportes significativos pueden señalarse, entre muchos otros, que ubicó las formas verbales en -ría, en el modo indicativo, a pesar de su carácter hipotético y semánticamente modal. Lo hizo en virtud del principio de la diferencia de naturaleza entre significado y realidad. Bello es uno de los hombres que ve por primera vez lo propio de la significación como algo no coincidente con lo significado. Así, los contextos semánticos, esto es, las situaciones designativas, nos revelan que cantaría oscila entre un futuro del pasado y una vaga noción intemporal (dijo que iría — "antes, ahora, luego"-; ¿irías al cine? "'ahora, luego, en cualquier momento”-; ¿lo harías? - “ilo habrás hecho?” “ilo haces?” “ilo harás?”-), con lo que solo parece diferenciarse del presente, en cuanto atañe al tiempo, en que se adentra o se puede adentrar en el pasado de la misma manera que en el futuro: al oponer ¿lo harías? a ¿lo haces? no se percibe diferencia temporal. Los demás residuos entran dentro del matiz semántico de probabilidad, de suerte que en un examen de la conjugación del verbo en español, se encuentra que la noción de tiempo puede no ser muchas veces más que un prejuicio. Aparentemente cantaría, que aparece en situaciones designativas tan diversas y contradictorias — tanto si se piensa en lo estrictamente temporal, como si nos centramos en lo puramente modal-, da la impresión de que no puede haber teoría capaz de cobijar tantos usos, tan dispares porque los estudiosos se han acercado a ellos con sus prejuicios de tiempo, de modo, etc. Sin embargo, lo hace Bello y, más adelante, autores como Rojo, que logran estructurar una concepción que incluye de manera sistémica todos los significados del pospretérito y los demás tiempos verbales.

Bello fija como valor primario el de pospretérito: indicador de un tiempo posterior al de un pretérito que le sirve de punto de partida: frente a dice que cantará, opone dijo que cantaría; en este caso, el valor semántico se muestra uniforme y sin ambigüedades, a diferencia de otras situaciones. De esta manera, no solo es el punto de partida formal, puesto que queda demostrada tanto su pertenencia al modo indicativo, como su diferencia opositiva con su pariente más cercano (no únicamente etimológico, el futuro), sino que todo lo demás ha de ponerse en relación con lo mostrado y que, asimismo, tiene una base formal tan sólida que a partir de ahí nadie volvió a hablar en este caso de que fueran formas del subjuntivo. Se ha dicho, incluso, que tanto cantaría como cantará participan de características modales, pero el asunto no ha pasado de ahí. Bello, para no comprometer su explicación, recurre al uso metafórico; es decir, un solo significado y una serie de matices contextuales para usar los términos actuales. "La relación de posterioridad se emplea metafóricamente para significar la consecuencia lógica, la probabilidad, la conjetura. Las formas cantaré, cantaría, habré cantado, habría cantado pierden así su valor temporal en cuanto a la relación en que hablamos" (Gili Gaya, 1958, p. 689).

El fenómeno, sin contradicción, del significado lingüístico de cantaría queda perfectamente explicado mediante el recurso del uso metafórico, como si no fuese el mismo significado aunque con otra designación - el cantaría de dijo que cantaría, el de cantaría ayer, o el de si le pagasen cantaría. Si todas estas designaciones son posibles, es porque son "coherentes entre sí", y Bello encuentra una manera para decir cómo un significado "es distinto de sí mismo"; además, presenta una hipótesis semántica que conviene a todos los usos, y da para ello la demostración oportuna mediante los recursos que permiten explicar las cosas de manera verosímil. Siguiendo esta línea, más tarde Guillermo Rojo fundamenta una teoría que demuestra la coherencia del sistema verbal del español.

Bello propone una nomenclatura para los tiempos verbales, que trata de acercarse al 
valor temporal que cada uno posee. Se parte de tres valores básicos: presente, pretérito y futuro, y luego, mediante la adición de los prefijos ante-, co- y pos(t)-, se crea una denominación que refleja casi exactamente los valores temporales tal como figuran en las fórmulas que se les han asignado.

La visión que tiene Bello de los valores de las formas verbales es fuertemente temporalista, por lo que las denominaciones que emplea tratan de reflejar solo el modo y el valor temporal.

\section{El sistema temporal de Reichenbach}

Entre las propuestas más interesantes relacionadas con la temporalidad está la de Reichenbach, cuya influencia se aprecia en teorías posteriores, como la de Rojo, en el caso de la lengua española.

Según el análisis de Hans Reichenbach, el significado de todos los tiempos verbales se obtiene del modo como se combinan tres entidades teóricas: el punto del habla $(\mathrm{S})^{2}$, que designa el momento de la enunciación, el punto del evento (E), que refiere al punto de la línea temporal donde se localiza el acontecimiento denotado por el predicado verbal y el punto de referencia (R), que se corresponde con un intervalo relevante con respecto al cual el hablante sitúa en la línea temporal el punto del evento. "Los tiempos verbales determinan el tiempo respecto al momento de la enunciación" (Reichenbach, 1947, p. 287).

El significado del tiempo de las formas verbales de una lengua natural permite establecer la ordenación temporal entre E, R y S.

2 En diferentes trabajos este punto es denominado $(H)$.
Simultaneidad:

1,2 (los puntos temporales 1 y 2 son simultáneos)

Precedencia:

1 - 2 (el momento 1 precede, es anterior al momento 2)

(a) A las doce la obra había terminado.

(b) A las doce ${ }_{\mathrm{R}}$ la obra había terminado.

$$
\begin{aligned}
& \text { R: "las doce". } \\
& \text { R-S. }
\end{aligned}
$$

(c) A las doce la obra había terminado.
R: "las doce".
$E-R$.

Según Reichenbach, estos son los subsistemas temporales (la coma indica relación de simultaneidad entre puntos temporales y el guion relación de sucesión; ver tabla 1).

Tabla 1

\begin{tabular}{|c|c|c|}
\hline $\begin{array}{l}\text { Relación } \\
\text { entre Ry S }\end{array}$ & $\begin{array}{l}\text { Relación } \\
\text { entre Ry E }\end{array}$ & $\begin{array}{l}\text { Subsistemas } \\
\text { temporales }\end{array}$ \\
\hline R - S ["pasado"] & $E-R$ & $E-R-S$ \\
\hline R - S ["pasado"] & $E, R$ & $E, R-S$ \\
\hline R - S ["pasado"] & $R-E$ & $\begin{array}{l}R-S, E \\
R-E-S \\
R-S-E\end{array}$ \\
\hline R, S ("presente") & $E-R$ & $E-R, S$ \\
\hline R, S ["presente"] & $E, R$ & $\mathrm{~S}, \mathrm{R}, \mathrm{E}$ \\
\hline R, S ("presente") & $R-E$ & $S, R-E$ \\
\hline S - R ["futuro"] & $E-R$ & $\begin{array}{l}S, E-R \\
S-E-R \\
E-S-R\end{array}$ \\
\hline S-R ["futuro"] & $E, R$ & $S-R, E$ \\
\hline S - R ["futuro") & $R-E$ & $S-R-E$ \\
\hline
\end{tabular}

Subsistemas temporales

Nota. Tomado de Reichenbach [1947].

El inventario de tiempos verbales propuesto por Reichenbach se presenta en la tabla 2. 
Tabla 2

Inventario de tiempos verbales

\begin{tabular}{|c|c|c|c|}
\hline Estructura & Nuevo nombre & Nombre según Bello & Forma verbal \\
\hline$E-R-S$ & Pasado anterior & Antecopretérito & Había trabajado \\
\hline$E, R-S$ & Pasado simple & $\begin{array}{l}\text { Pretérito } \\
\text { Copretérito }\end{array}$ & $\begin{array}{l}\text { Trabajé } \\
\text { Trabajaba }\end{array}$ \\
\hline $\begin{array}{l}R-S, E \\
R-E-S \\
R-S-E\end{array}$ & Pasado posterior & Pospretérito & Trabajaría \\
\hline$S, R-E$ & Presente posterior & Futuro & Trabajaré (ahora) \\
\hline$S, R, E$ & Presente simple & Presente & Trabajo \\
\hline$E-R, S$ & Presente posterior & Futuro & Trabajaré ( mañana) \\
\hline $\begin{array}{l}S-E-R \\
S, E-R \\
S-E-R\end{array}$ & Futuro anterior & Antefuturo & Habré trabajado \\
\hline$S-R, E$ & Futuro simple & Futuro & Trabajaré \\
\hline$S-R-E$ & Futuro posterior & - & - \\
\hline
\end{tabular}

Nota. Tomado de Reichenbach (1947).

La posición de $\mathrm{R}$ con respecto a $\mathrm{S}$ se indica con los términos pasado ( $R$ - S), presente (SR) y futuro ( $\mathrm{S}-\mathrm{R})$. La posición de $\mathrm{E}$ con respecto a $\mathrm{R}$ se indica con los términos anterior ( $E$ - R), simple (RE) y posterior ( $\mathrm{R}$ - E). Un tiempo como el pasado simple de Reichenbach significa, por ejemplo, que el evento denotado por el predicado se sitúa en un punto de la línea temporal simultáneo con un punto de referencia que, a su vez, es anterior al punto del habla.

Que el punto del evento preceda, coincida o siga al punto del habla, dice Reichenbach, no da lugar a ninguna distinción temporal relevante; de hecho, se da el caso de que corresponden a un mismo tiempo verbal estructuras temporales (a partir de ahora ET) que son distintas porque el punto de evento y el punto del habla mantienen entre sí relaciones temporales diferentes (véase las ET que se asignan al pospretérito y al antefuturo.)

Uno de los principales atractivos del sistema temporal de Reichenbach es su carácter restrictivo, es decir, el hecho de que el número de tiempos verbales esté limitado por las combinaciones posibles entre tres puntos temporales. Según opiniones de diferentes autores, es este carácter lo que convierte el análisis de los tiempos de Reichenbach en superior a los ofrecidos por la semántica generativa y por la lógica temporal (Reichenbach, 1947). Un sistema como este predice que haya tantos tiempos verbales como estructuras resulten de la combinación de los tres puntos del habla, del evento y de la referencia.

Los tiempos verbales que pueden darse en las lenguas naturales, según la tabla 2, son nueve. Aquí se aprecia también que la correspondencia entre tiempos y formas verbales no es unívoca. Por un lado, a las formas verbales trabajé y trabajaba se les asigna la misma ET; por otro, se toma en consideración un tiempo como el futuro posterior, que en lenguas como el español no puede ponerse en relación con ninguna forma verbal. El propio Reichenbach da una explicación para uno y otro hecho. No se proponen ET distintas para tiempos como el pretérito y el copretérito del español porque la diferencia entre ambos no está en la indicación de tiempo que realizan. Tanto el pretérito como el copretérito significan que el acontecimiento denotado por el predicado verbal se sitúa en un punto de la línea temporal que coincide con un punto de referencia anterior al momento del habla. Lo que diferencia a un tiempo del otro es el carácter 
de tiempo extendido del copretérito; esto es, el copretérito expresa la duración del evento. En este trabajo, se adopta una posición contraria, ya que según Reichenbach la diferencia entre ambas formas es solo aspectual; sin embargo, según Rojo y otros autores, sin obviar los matices aspectuales, existen claras diferencias temporales entre ambos tiempos verbales: el pretérito expresa anterioridad respecto al momento del habla y el copretérito, simultaneidad a un momento anterior en relación con el momento del habla. Por otra parte, las ET de la tabla 2 traducen las posibilidades de la razón, no pretenden pertenecer a lengua alguna. En consecuencia, si Reichenbach postula una ET para el significado de posterioridad en el futuro es porque prevé que haya lenguas en las que esté cubierta la casilla vacía que existe en el paradigma de las formas verbales del español.

La ausencia en el inventario de tiempos verbales de la tabla 2 de un tiempo como antepospretérito no se justifica. Una forma verbal como habría trabajado precisa para su interpretación de un segundo punto de referencia. En términos de la teoría de Reichenbach (se representa en la figura 1 que sigue a este párrafo), significa que el evento denotado por el predicado se sitúa en un punto de la línea temporal anterior a otro punto ( $\mathrm{R}^{\prime}$ en (1b)) que, a su vez, es posterior a un punto de referencia que precede a S. Un ejemplo de esto es que la representación que correspondería a la oración subordinada de (1a) es la de (1b); debe notarse que no se sitúan en la línea temporal ni E ni R'. Puesto que la relación entre puntos temporales se establece de dos en dos, solo podemos saber que R' sigue a $R$ pero no qué lugar ocupa en la línea temporal respecto de $\mathrm{S}$, y lo mismo ocurre con E (el punto temporal que se sitúa a la izquierda del símbolo < precede al punto temporal que se sitúa a su derecha; véase figura 1). a. Ileana aseguró que se habría limpiado la casa antes de que llegaran los niños.

b.

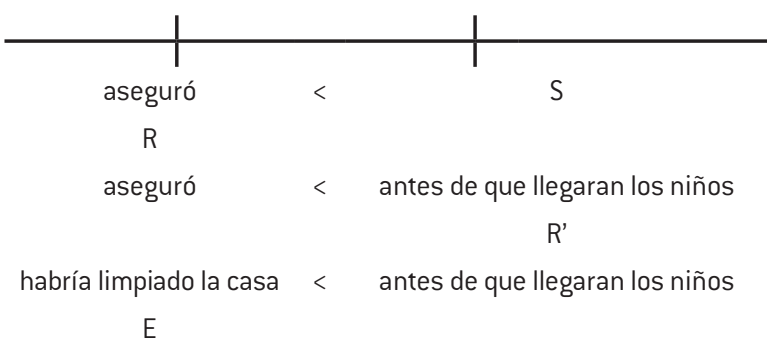

FIGURA 1. Representación del antepospretérito. Tomado de Reichenbach (1947).

La expresión de tiempo antes de que llegaran niños modifica un punto de la línea temporal necesario para la interpretación del antepospretérito. Pero en un sistema como el de Reichenbach, en el que hay tantos tiempos verbales como combinaciones posibles entre puntos temporales, no sería posible limitarse a introducir este cuadro primitivo teórico en la ET del antepospretérito. Habría que introducirlo también en tiempos que, al menos aparentemente, no precisan de él para su interpretación; la ET del presente, por ejemplo, pasaría a ser S.R,R' E. Además, al aumentar el número de puntos temporales serían más abundantes las combinaciones que se podrían efectuar con ellos y muy superior el número de tiempos verbales al que darían lugar. No obstante, más problemático para la teoría de Reichenbach que el hecho de que varios de estos tiempos no tuvieran una correspondencia real con formas verbales es que, una vez introducido un segundo punto de referencia, no habrá razón para no seguir añadiendo nuevos puntos de referencia. Por lo tanto, esta propuesta perdería su carácter restrictivo (Reichenbach, 1947).

A continuación, se presenta la descripción del valor de las formas verbales del español en el sistema de Reichenbach: 
había trabajado

trabajé

trabajaba

hube trabajado

trabajaría

habría trabajado

trabajo

he trabajado

trabajaré

habré trabajado

trabaje

trabajara-se

hubiera-se trabajado

haya trabajado

- Trabajaba, trabajó

(1) a. (Ayer, a las seis) $)_{\mathrm{R}}$ [me prestó un libro muy bueno] $]_{E}$.

b. (Ayer, a las seis) $)_{\mathrm{R}}$ [tenía dolor de cabeza $]_{\mathrm{E}}$.

(2) Aquí vivía/vivió mi abuela.

- Había trabajado, hubo trabajado

(3) $\{$ En cuanto/no bien/apenas $\}$ había/hubo terminado la película salimos del cine.

A las seis había terminado todo.

* A las seis hubo terminado todo.
- Trabajo

(4) Tengo frío (*ayer/hoy/*mañana).

(5) Ahora mismo te llamo.

- Trabajaré

(6) [El año que viene $]_{R}$ [iré de vacaciones a Santiago $]_{E}$

(7) Ahora llamo/llamaré/voy a llamar.

- Habré trabajado

(8) (Mañana a las seis $]_{R}$ [pasaré el trabajo a la computadora $]_{E}$.

- He trabajado

(9) (\{Este momento, esta mañana, hoy, esta semana, este mes, este año, este siglo, esta era/*ayer...\}) ha sido una época maravillosa.

(10)He tenido dos accidentes en mi vida (=desde que nací hasta el momento de hablar).

- Trabajaría

(11) $[\text { Ayer }]_{R}$ me prometió que [volvería $]_{\mathrm{E}}$

(12) $[\text { Ayer }]_{R}$ me prometió que [volvería $]_{E}$, y ha llegado esta mañana (R-E-S)

$[\text { Ayer }]_{R}$ me prometió que [volvería $]_{E}, y$ ahora entra (R-E,S)

$[\text { Ayer }]_{\mathrm{R}}$ me prometió que [volvería $]_{\mathrm{E}}$ : llegará mañana (R-S-E) 
- Habría trabajado

(13) [Hace unos meses $]_{R 1}$ me dijo que [en primavera $]_{R 2}$ [habría nacido su segundo hijo $]_{E}$.

$\mathrm{R}_{1}-\mathrm{S}$

$\mathrm{R}_{1}-\mathrm{R}_{2}$

$E-R_{2}$

(14) (s yo, ahora, digo que) $\left[_{R 1}\right.$ Ayer prometiste] que $\left[_{R 2}\right.$ a las seis] [ habrías terminado el trabajo].
La representación del pospretérito en los ejemplos (11) y (12) son útiles para el análisis del corpus que se realiza en esta investigación, ya que mientras Rojo representa este tiempo como un vector que indica posterioridad a un momento anterior al del habla, Reichenbach, tomando en cuenta las referencias (R), representa además cuándo denota a la vez un evento anterior respecto al momento del habla.

Se podrían resumir los subsistemas temporales del español aplicando la teoría de Reichenbach como se muestra en la tabla 3.

Tabla 3

Resumen de los subsistemas temporales del español aplicando la teoría de Reichenbach.

\begin{tabular}{|c|c|c|c|}
\hline $\begin{array}{l}\text { Relación } \\
\text { entre Ry S }\end{array}$ & $\begin{array}{l}\text { Relación } \\
\text { entre Ry E }\end{array}$ & Subsistemas temporales & Formas verbales que expresan esta relación \\
\hline R - S ["pasado"] & $E-R$ & $E-R-S$ & Había trabajado \\
\hline R-S ["pasado"] & $E, R$ & $E, R-S$ & $\begin{array}{l}\text { Trabajé } \\
\text { Trabajaba }\end{array}$ \\
\hline R - S ["pasado"] & $R-E$ & $\begin{array}{l}R-S, E \\
R-E-S \\
R-S-E\end{array}$ & Trabajaría \\
\hline & & & Habría trabajado \\
\hline R, S ["presente"] & $E-R$ & $E-R, S$ & He trabajado \\
\hline R, S ["presente"] & $E, R$ & $S, R, E$ & Trabajo \\
\hline R, S ["presente"] & $R-E$ & $S, R-E$ & ¿Trabajo?, ¿trabajaré? \\
\hline S - R ["futuro") & $E-R$ & $\begin{array}{l}S, E-R \\
S-E-R \\
E-S-R\end{array}$ & Habré trabajado \\
\hline S - R ["futuro") & $E, R$ & $S-R, E$ & Trabajaré \\
\hline S - R ("futuro") & $R-E$ & $S-R-E$ & ¿? \\
\hline
\end{tabular}

Nota. Tomado de Reichenbach (1947).

Se podría explicar el antepospretérito, no considerado en la propuesta de Reichenbach, con el siguiente esquema:

$$
\begin{aligned}
& R_{1}-S \\
& R_{1}-R_{2} \\
& E-R_{2}
\end{aligned}
$$

habría trabajado

(syo, ahora, digo que) $\left[_{R 1}\right.$ Ayer prometiste] que ${ }_{R 2}$ a las seis]

[ habrías terminado el trabajo].
$E_{\text {habrías terminado el trabajo }}-\mathrm{R}_{1 \text { ayer }}-\mathrm{R}_{2 \text { a las seis }}-\mathrm{H}_{\mathrm{yo} \text {, ahora, }}$ digo que

$\mathrm{E}_{\text {habrías terminado el trabajo }}-\mathrm{R}_{1 \text { ayer }}-\mathrm{H}_{\mathrm{yo} \text {, ahora, digo que }}-\mathrm{R}_{2}$ a las seis 


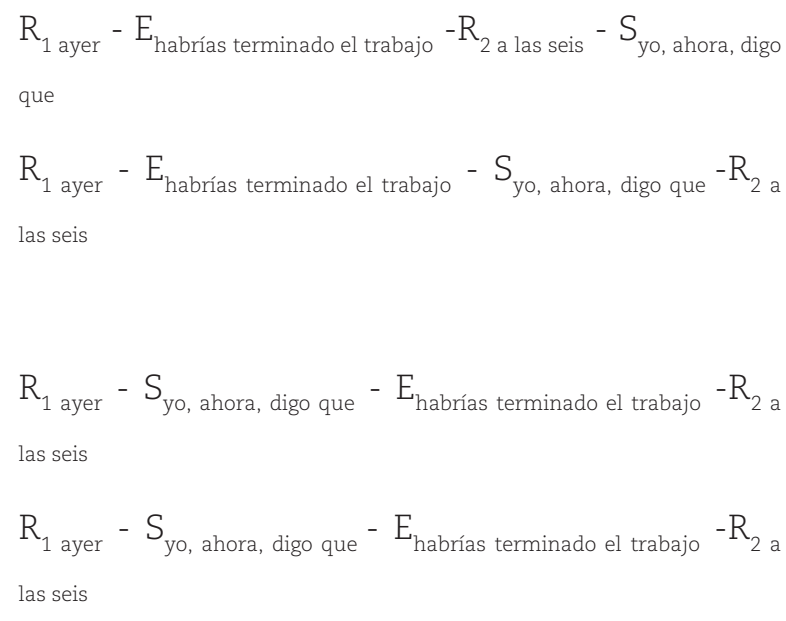

Como novedad en la teoría de Reichenbach, se destaca su carácter restrictivo, es decir, el hecho de que proporciona un modo de limitar el número de tiempos que pueden darse en las lenguas naturales; por otro lado, deja abierta la posibilidad de establecer un paralelismo estricto entre información morfológica y significado de los tiempos, que puede ser tomado como punto de partida para su representación sintáctica. Como limitaciones, se señala que quedan casillas vacías, que hay varios elementos en la misma casilla y que hay elementos sin casilla, como el antepospretérito del español.

Por otro lado, ejemplos como los siguientes quedan fuera del análisis:

"Ya verás cómo mañana me pasa algo".

"En el siglo xIx, la industria evoluciona muy deprisa”

(empleos prospectivo y retrospectivo del presente del modo indicativo).

“¿Qué edad tiene? No sé, ahora tendrá unos veinte años".

"Cuando la viste, ¿qué edad crees que tenía? No sé, tendría unos veinte años” (futuro y condicional de conjetura, futuro de probabilidad o futuro epistémico). (Real Academia Española [RAE], 2010, p. 436).

“¿Jugamos? Yo era el policía y tú un ladrón que se escapaba, ¿vale?"

(imperfecto onírico o de figuración; RAE, 2010, p. 446).

“¿Podría probarme esta falda?”

(condicional de modestia o de cortesía; RAE, 2010, p. 436).

En el caso del español, otros valores y tiempos quedan sin explicación, como el antepospretérito.

\section{Lamíquiz: la actualidad}

Lamíquiz (1972), citando a Pottier, define el concepto gramatical del verbo: "Verbo es tiempo: complejo sémico combinación del modo, de la actualidad y de la época" (p. 59). Esta concepción destaca la interrelación entre los significados del verbo, que van más allá del tiempo, al que otorga primacía.

En su trabajo Morfosintaxis estructural del verbo español, explica los conceptos de modo, actualidad y tiempo lingüístico. El autor comienza su análisis con la oposición de actualidad. Explica que E. Benveniste da la noción de los niveles de actualidad al afirmar que los tiempos de un verbo "no se emplean como miembros de un sistema único", sino que "se distribuyen en dos sistemas diferenciados y complementarios. Cada uno de ellos incluye solo una parte de los tiempos del verbo". Y añade: "Estos dos sistemas manifiestan dos planos de enunciación diferentes: el de la historia y el del discurso" (p. 60). La serie de formas temporales del nivel actual corresponde al discurso y la serie de formas de nivel inactual, a la historia. Las formas temporales de la enunciación 
narrativa se sitúan a nivel inactual en el relato de un acontecimiento, y las formas temporales de la enunciación del discurso, en la perspectiva del nivel actual (Lamíquiz, 1972).

Coseriu (1996) los presenta como nivel de tiempo o nivel: en el primero, que coincide con la línea del tiempo que va a través del presente, se halla el nivel actual, cuyo centro es el presente. Como trasfondo están las acciones, ${ }^{3}$ que no corresponden directamente a esa línea de tiempo y que en sí representan el trasfondo de otra acción, en el nivel inactual. Su centro es el copretérito.

Dice Lamíquiz que tras el clasificador subjetivo de modo, hay que considerar un segundo clasificador del hablante, también subjetivo: la actualidad.

El sistema verbal español distingue dos planos o niveles en cada modo: actual e inactual. En oposición binaria y ordenados en cronología lógica, se debe indicar:

actual / inactual

$+$

Este funcionamiento de la sencilla oposición binaria se apoya en las formas correspondientes. En el indicativo, a las formas actuales canté, canto, cantaré y a las formas inactuales: cantara ${ }^{(1)}$, cantaba, cantaría.

Esta correspondencia se manifiesta en la dependencia funcional o subordinación, patente en el paso del estilo directo al indirecto:

el presente actual corresponde al imperfecto inactual

dijo: canto $\longrightarrow$ dijo que cantaba

al futuro de nivel actual corresponde el pospretérito en el nivel inactual

3 En el presente trabajo se emplea el término evento para denotar lo expresado por el verbo. dijo: cantaré $\longrightarrow$ dijo que cantaría

y en el pasado

dijo: canté $\longrightarrow$ dijo que cantara ${ }^{(1)}$ (= había cantado)

En el modo subjuntivo y a nivel actual, el verbo español presenta dos formas:

cantase cante

En el nivel inactual se deben considerar las formas:

cantara $^{(2)}$ cantare

Acerca de los niveles de actualidad en el discurso, Lamíquiz (1972) cita a H. Weinrich, que caracteriza los dos grupos de tiempos como pertenecientes al mundo comentado y al mundo narrado, actual e inactual, respectivamente. El mismo Weinrich señala, además, las consecuencias contextuales de esos dos mundos y las aplica a una estilística del discurso que, naturalmente, aprovecha el funcionamiento de la estructura temporal o verbal.

De igual forma, el autor sigue a Lindgren y atribuye al primer grupo, nivel actual, una preponderancia estadística en las partes dialogadas y al segundo grupo, nivel inactual, un gran predominio relativo en el relato del narrador. Al relacionar los niveles de actualidad y los deícticos, entiende, como Pottier, estos últimos como los elementos "situativos ligados a las circunstancias del acto de discurso" (1972, p. 68).

Las formas verbales del nivel actual irán acompañadas, por motivos contextuales de coherencia en la comunicación, por el adverbial espacial aquí, que pasará automáticamente a ser allí junto a las formas inactuales.

Por las mismas razones, a nivel de discurso, en los sintagmas verbales que ofrezcan una forma verbal de nivel actual, se encontrarán los adverbios temporales ahora, hoy, ayer, 
mañana, que serán cambiados inmediatamente por entonces, aquel día, la víspera, el día siguiente, en cuanto se salte al nivel inactual con las formas verbales correspondientes, en consonancia con la noción temporal que cada uno de esos adverbios expresa en la lengua (Lamíquiz, 1972).

Las formas actuales se encuentran en coexistencia conceptual con las formas demostrativas de la deixis ${ }^{4}$ ad oculos bühlriana o mostración de presencia, que se caracteriza por llevar necesariamente inherente una "referencia personal" a las tres personas del discurso de actualidad.

Sin embargo, con las formas verbales inactuales se emplearán las formas demostrativas de la deixis anafórica, es decir, de la mostración de ausencia, cuyas formas no llevan en sí alguna referencia personal, pues en este nivel inactual los demostrativos pasan a realizar la función de simples referentes de la situación en el discurso del elemento que señalan, indicación espacial de la distancia a la que se encuentran, en proximidad o lejanía, en la linealidad del signo lingüístico.

En el comienzo del epígrafe dedicado a la oposición de época, Lamíquiz define el concepto de época verbal; reitera que verbo es tiempo: gramaticalmente verbal equivale a temporal. Así, desde este punto de vista, hablar de tiempos del verbo le parece una redundancia y, desde otro punto de vista, "más conveniente parece utilizar otra terminología, y eliminar la peligrosa anfibología de tiempo, que induce a error, ya que tiempo, igual a verbo, es una entidad más compleja, que incluye la época puesto que todo tiempo lleva implícita una

4 Deixis: procedimiento que consiste en establecer la referencia de una unidad lingüística a partir de alguno de los elementos que están presentes en el acto enunciativo; por ejemplo, los complementos temporales orientados al momento del habla (ahora, ayer, el año pasado, etcétera). época" (1972, p. 70). Así queda especificada su nomenclatura básica al respecto, donde diferencia tiempo y época, exacto paralelismo conceptual terminológico en el alemán Zeit y Tempus, y con el inglés time y tense.

Además, define el tiempo lingüístico como el tiempo de la lengua y destaca que es indispensable distinguir la diferencia entre situar un acontecimiento en el tiempo cronológico e insertarlo en el tiempo de la lengua. El tiempo lingüístico presenta como peculiaridad "que se vincula orgánicamente con el ejercicio de la palabra y está definido y ordenado en función del discurso" (1972, p. 70).

Hay, pues, dos referencias. La primera instituye un presente lingüístico: el momento del discurso, presente intersubjetivo al quedar automáticamente admitido como tal por parte del hablante y por parte del oyente $u$ oyentes y que, además, utiliza el valor significativo de los deícticos: aquí, hoy, ahora, este. Este presente lingüístico no recurre a ninguna referencia axial del tiempo cronológico, admite cualquiera de sus puntos e incluso los va recorriendo todos, se vuelve a situar cada vez que el hablante habla. Pero, al mismo tiempo, con él se instituye una referencia en el discurso. Este presente lingüístico queda convertido en centro axial de la comunicación, genera otros momentos rodeados por sus correspondientes deícticos, que pueden servir también de referencia.

Para explicar el funcionamiento de la época, Lamíquiz indica que lo expuesto anteriormente constituye la base de las épocas absolutas verbales que el enfoque temporal de la lengua va a utilizar. El presente, implícito por naturaleza, es "fundamento de las oposiciones temporales de la lengua" (p. 74): atemporal, no tiempo, se desplaza conforme progresa el discurso, ordena ese discurso como línea divisoria entre las dos épocas temporales: 
- El momento que debe ser evocado por el recuerdo, retrospectivo, ya experimentado: el pasado, marcado.

- El momento que aún no es presente, que aparece en prospección, no experimentado todavía, pero que se temporaliza previendo una experiencia: el futuro, no marcado.

Esto permite sistematizar el funcionamiento como se muestra en la figura 2 (1972, p. 74).

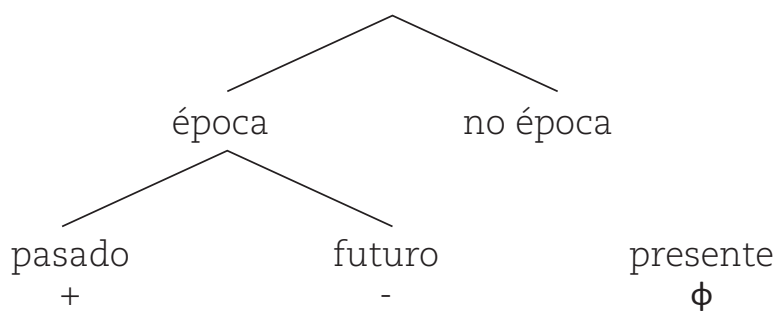

FIGURA 2. Funcionamiento de la época. Tomado de Lamíquiz (1972).

Ese funcionamiento se asume con las consecuencias que se derivan de este contraste asimétrico en un enfoque de cronología lógica.

Estas épocas absolutas sirven de base para la complejidad en el discurso. Cada una de ellas puede convertirse, a su vez, en punto de referencia temporal para señalar una contemporaneidad, una anterioridad y una posterioridad, enlazadas de manera indirecta con el presente lingüístico absoluto de intersubjetividad: nacen las épocas relativas.

Andrés Bello lo distinguió cuando empleó en su nomenclatura los términos co-, ante- y post-presente, co-, ante- y post-futuro y co-, ante- y post-pasado. También se debe tener en cuenta otro tipo de época igualmente relativa: cada forma verbal simple dispone de su correspondiente forma compuesta que manifiesta un valor de época en anterioridad en relación con ella.

Además, hay que tener en cuenta que en el discurso una época no solamente puede quedar expresada por medios intrínsecos, del nivel morfosintáctico, dependientes de la estructura del sistema verbal; también puede ir comunicada por medios extrínsecos, lexemáticos, del nivel de significación, por ejemplo, una fecha cronológica o toda una serie de deícticos temporales llamados, por tradición, adverbios de tiempo.

Para Lamíquiz (1972) esta diferenciación lingüística de medios intrínsecos y extrínsecos permite una clara distinción de niveles, cuya precisión es básica en atención a un nivel científico necesario.

En resumen: las tres formas situadas en el nivel actual del modo indicativo: canté, canto y cantaré sirven para manifestar la época en función del presente lingüístico o momento de actualizar el discurso, es decir, época absoluta. A su alrededor, relacionadas intrínsecamente con ellas o extrínsecamente con elementos léxicos del discurso, todas las demás formas, que expresarán época relativa. Y todas estas formas simples, tanto las absolutas como las relativas, dispondrán de su correspondiente compuesta, que expresará la anterioridad relativa a la época absoluta señalada por la forma simple que le sirve de base o relación.

Lamíquiz presenta el sistema verbal del español y considera que las tres marcas esenciales que constituyen el complejo sémico verbal son el funcionamiento modal, el funcionamiento de los niveles de actualidad y el funcionamiento de la época verbal (véase tabla 4). 


\begin{tabular}{|c|c|c|c|c|}
\hline & & $\begin{array}{l}\text { pasado } \\
+\end{array}$ & $\begin{array}{c}\text { presente } \\
\phi\end{array}$ & futuro \\
\hline \multirow{2}{*}{ 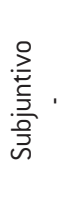 } & 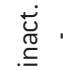 & & cantara $^{[2]}$ & cantare \\
\hline & $\underset{\sigma}{\dot{\sigma}}+$ & cantase & cante & \\
\hline \multirow{2}{*}{ 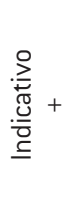 } & 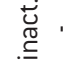 & cantara $^{(1)}$ & cantaba & cantaría \\
\hline & $\dot{\tilde{\sigma}}+$ & canté & canto & cantaré \\
\hline
\end{tabular}

Nota. Tomado de Lamíquiz [1974].

En el sistema se encuentran la oposición de modo: indicativo, marcado, frente a subjuntivo, no marcado; en cada uno de estos modos la oposición de nivel: actual, marcado, frente a inactual, no marcado, y en cada nivel la marca de época: pasado, marcado, en oposición a futuro, no marcado, el presente es de marca ф (Lamíquiz, 1972). Únicamente señala las formas fundamentales simples, pero recuerda que cada una de ellas, o la serie paradigmática que representa, dispone de su correspondiente forma compuesta, que representa "la acción pasada en relación con la época de referencia”.

\section{Ángel López García: temporalidad, coherencia temporal y actitud temporal}

En su trabajo La interpretación metalingüística de los tiempos, modos y aspectos del español: ensayo de fundamentación, López García parte de reconocer la enorme divergencia que hay al enfocar en español las categorías clásicas de tiempo, modo y aspecto. Trata de dar una explicación multifactorial y repasa las teorías divergentes en cuanto al tiempo.
Su exposición comienza haciendo referencia a la temporalidad y, al igual que Bello y Rojo, considera cada valor temporal como una situación relacionada con cierto origen que, a su vez, puede estar orientado de forma secundaria o no.

La coherencia temporal ha sido la postura de la gramática tradicional, expuesta por la RAE en sus ediciones de 1917 y 1931. Típicamente hace intervenir la conformidad entre sujeto y predicado a la hora de definir los diferentes tiempos.

Las demás formas del verbo castellano no comprendidas en el modo infinitivo se agrupan dentro de los restantes modos, formando los tiempos gramaticales, que denotan la época o momento en que sucede lo que el verbo significa. Por su naturaleza y significación se dividen en dos series: una que comprende los tiempos simples, y otra, los compuestos. Unos y otros denotan lo expresado por el verbo, como presente, pasado y futuro, con relación al momento en que se habla. (p. 43) 
Según López García, para Alarcos, el punto de vista relativo al tiempo que se ha llamado coherencia temporal (de la proposición) es de índole lógico-semántica: los distintos valores temporales consideran la posición relativa del sujeto y del predicado del enunciado respecto al estado de cosas coincidente con la enunciación.

La tercera postura es la de actitud temporal o nivel de actualidad. Lo típico de este planteamiento es la concepción del tiempo como algo filtrado por la subjetividad del hablante: actuales serían las formas que tienen pertinencia en el mundo del decir, inactuales las que solo la tiene en el mundo de lo dicho. Lamíquiz (1982) dice: "Al igual que el modo, nos encontramos ante un caracterizador subjetivo, ya que depende de la apreciación del hablante ante el acontecimiento temporal" (p. 41).

Para López García, es muy frecuente que los tratamientos del sistema temporal del verbo acudan de manera simultánea a varias de estas nociones; por ejemplo, Coseriu concibe un esquema de doble entrada en el que se combinan la perspectiva o temporalidad (retrospectiva/paralela/prospectiva), que suponen una orientación deíctica respecto al momento del habla, junto con la oposición plano de actualidad (actual/inactual), que es la actitud temporal. No obstante, en la medida en que la temporalidad obligatoria es solo la de la perspectiva primaria, y así deja abierta la posibilidad de perspectivas secundarias, se da implícitamente la introducción de una tercera oposición de tipo de perspectiva: para cada tiempo existen ampliaciones hacia el pasado o hacia el futuro que parten del tiempo ya constituido - voy a hacer es una perspectiva secundaria relativa a hago, por ejemplo, iré a hacer lo es respecto a haré-; pero esas ampliaciones se basan en una reestructuración operada dentro de tiempos estables, esto es, previamente coherentes: si el futuro haré vale por todo el tiempo, iré a hacer no será otro tiempo, sino parte del anterior, y por consiguiente parte del sujeto o del predicado de la oración que se manifiesta.

En el trabajo de López García, se explica que los tratamientos del tiempo verbal pueden centrarse en la temporalidad, en la coherencia temporal, o en la actualidad, o aludir a las tres nociones simultáneamente. La primera se organiza sobre un origen de coordenadas que suele coincidir con el momento del habla; la segunda, es más bien lógico-semántica, y alude a la posición relativa entre el sujeto y el predicado, y la tercera tiene en cuenta los factores subjetivos (López García, I990).

El tiempo verbal se estructura en español conforme a tres parámetros. El autor de este trabajo considera que la arista más conocida en los medios docentes, y específicamente en lo relacionado con la enseñanza del español como lengua extranjera, es la referida a la temporalidad, con enfoque semasiológico, pues lo más frecuente es partir de los valores y usos atribuidos a las formas verbales a través de los ejemplos que se analizan. No obstante, no se da el tratamiento adecuado a las nociones de "anterioridad", "simultaneidad” y "posterioridad" expresadas por los tiempos verbales.

Si bien la temporalidad constituye la versión deíctica más clara del tiempo verbal, en realidad la coherencia temporal y la actitud temporal (actualidad) también representan un tipo indirecto de deixis, a saber, la posición del sujeto respecto al predicado, o la del enunciado en relación con el hablante.

Refiere López García que es comúnmente aceptado que el sistema temporal de las lenguas del mundo se establece respecto al momento del habla, es decir, con ahora, como señala B. Comrie (1985), y que R. Jakobson estableció el proceso de la enunciación como eje medidor para el proceso del enunciado, lo cual implica atender preferentemente al "aquí", es decir, al referente. No han faltado gramáticos 
proclives a enfatizar el carácter psicológico de la deixis temporal, o sea, la influencia del yo, como K. Heger. Las tres formas de captación de los sistemas temporales se corresponden con las tres maneras de entender el origen de coordenadas del sistema de los tiempos.

Los tratamientos centrados especialmente en momento del habla se articulan en torno a la temporalidad, y conciben tres tiempos fundamentales, cualquiera que sea su denominación: pasado, presente y futuro.

Los tratamientos que se ocupan en particular de la coherencia temporal están polarizados en torno al carácter referencial del origen de coordenadas, es decir, el origen de la enunciación. De ahí se siguen dos valores temporales fundamentales, el de la coherencia máxima y el de la coherencia relajada, lo cual conduce a un tiempo neutro básico en el que no hay desajustes ni hacia el pasado ni hacia el futuro, es decir, un presente de máxima coherencia al que se oponen todos los demás tiempos parciales (véase tabla 5). Esta es la postura de Alarcos.

Tabla 5

Caracterización temporal

\begin{tabular}{|c|c|}
\hline $\begin{array}{l}\text { Tiempo de factor } \\
\text { preponderante }\end{array}$ & $\begin{array}{l}\text { Tipo de caracterización } \\
\text { temporal }\end{array}$ \\
\hline $\begin{array}{l}\text { El origen como vector (ahora) } \\
\text { El origen como proceso (aquí) } \\
\text { El origen como sujeto (yo) }\end{array}$ & $\begin{array}{l}\text { Temporalidad } \\
\text { Coherencia temporal } \\
\text { Actitud temporal }\end{array}$ \\
\hline
\end{tabular}

Nota. Tomado de López García [1990].

Los tiempos verbales de cualquier lengua tienen simultáneamente un valor de temporalidad, un valor de coherencia temporal y un valor de actitud temporal o actualidad. Según López García, en español el conjunto de valores temporales se ordena de forma coherencia temporal/temporalidad/actitud temporal.

Los tratamientos centrados en la actitud temporal oponen un conjunto de formas características del estilo directo a un conjunto de formas que se emplean preferentemente en el estilo indirecto; es decir, enfatizan el grado de dependencia de las formas temporales respecto al sujeto hablante (el estilo directo es inmediato, el estilo indirecto, mediato y, a menudo, puesto en boca de otro emisor; López García, 1990). Con este trabajo se ha podido constatar que los profesores de español como lengua extranjera, con frecuencia, al explicar el empleo de diferentes tiempos verbales en el estilo indirecto, omiten el análisis de los valores temporales que estos portan. Por ejemplo, se explica que una forma verbal que aparece en tiempo futuro del indicativo en el estilo directo debe pasar a pospretérito en el estilo indirecto si el verbo introductor está en algún tiempo del pasado; pero no indican que ello es porque expresa un evento posterior con relación a un momento anterior al momento del habla.

"Vendré".

"Dijo que vendría".

En español el conjunto de valores temporales se ordena de la forma coherencia temporal/temporalidad/actitud temporal: cada tiempo existe en el paradigma de la conjugación porque hay un valor de coherencia temporal que lo avala, vive en la oración, simple y compuesta, atendiendo a patrones de temporalidad, y tiende a ser utilizado en el texto, siguiendo las pautas del estilo directo que le impone su valor de actitud temporal.

La propuesta de Rojo está apoyada básicamente en la temporalidad (véase tabla 6):

Tabla 6

Propuesta de Rojo

\begin{tabular}{|l|l|l|l|}
\cline { 2 - 4 } \multicolumn{1}{c|}{} & $-V$ & oV & $+V$ \\
\hline 0 & L]legué & Llego & Llegaré \\
\hline $0-V$ & $\begin{array}{l}\text { Había llegado } \\
\text { Hube llegado }\end{array}$ & Llegaba & Llegaría \\
\hline OoV & He llegado & 0 & 0 \\
\hline $0+V$ & Habré llegado & 0 & 0 \\
\hline$(0-V)+V$ & Habría llegado & 0 & \\
\hline
\end{tabular}

Nota. Tomado de Rojo [1974]. 
Será analizada más profundamente en un acápite aparte de este trabajo, atendiendo a la afinidad con el tema tratado.

La propuesta de Lamíquiz (1990, p. 118) basada básicamente en el nivel de actualidad se resume como sigue (véase tabla 7).

Los valores de la coherencia temporal del español, según Alarcos, sin casillas vacías, se presentan en la tabla 8 (Lamíquiz, 1990, p. 119).
Tabla ?

Propuesta de Lamíquiz

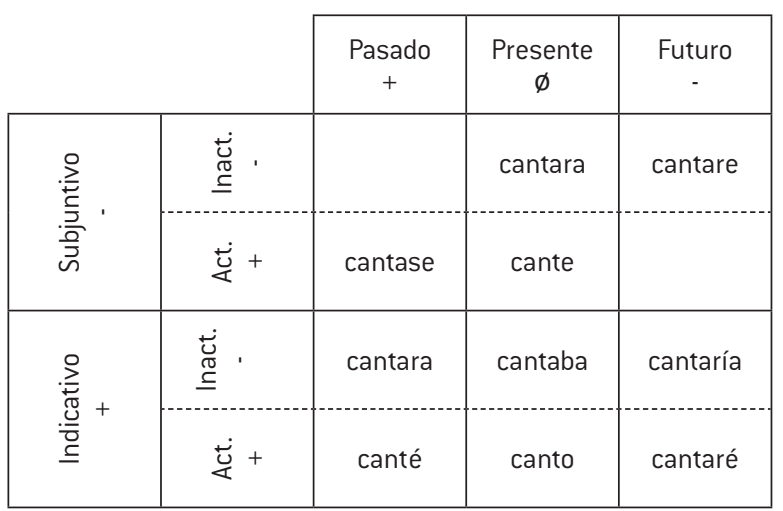

Nota. Tomado de Lamíquiz [1972].

Tabla 8

Valores de la coherencia temporal

\begin{tabular}{|c|c|c|c|c|c|c|c|c|c|}
\hline \multicolumn{3}{|c|}{ Formas no personales } & \multicolumn{7}{|c|}{ Formas personales } \\
\hline $\begin{array}{l}: \frac{c}{n} \\
: \frac{0}{n} \\
\stackrel{0}{d} \\
. \frac{n}{=}\end{array}$ & \multicolumn{2}{|c|}{ Con distensión } & \multicolumn{5}{|c|}{ Sin matiz modal indicativo } & \multicolumn{2}{|c|}{ Con matiz modal subjuntivo } \\
\hline \multirow{4}{*}{ 竞堇 } & $\begin{array}{l}\text { Sin } \\
\text { término }\end{array}$ & $\begin{array}{l}\text { Con } \\
\text { término }\end{array}$ & No indican & pasado & & icando $\mathrm{p}$ & & $\begin{array}{l}\text { No indicando } \\
\text { pasado }\end{array}$ & $\begin{array}{l}\text { Indicando } \\
\text { pasado }\end{array}$ \\
\hline & \multirow{3}{*}{ 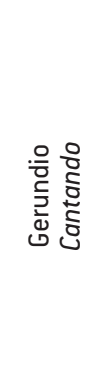 } & \multirow{3}{*}{ 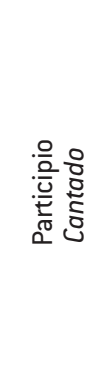 } & $\begin{array}{l}\text { No indicando } \\
\text { futuro }\end{array}$ & $\begin{array}{l}\text { Indicando } \\
\text { futuro }\end{array}$ & No indic & o futuro & $\begin{array}{l}\text { Indicando } \\
\text { futuro }\end{array}$ & & \\
\hline & & & & & $\begin{array}{l}\text { Sin } \\
\text { término }\end{array}$ & $\begin{array}{l}\text { Con } \\
\text { término }\end{array}$ & \multirow[b]{2}{*}{ 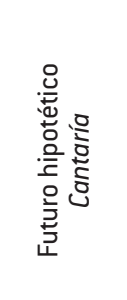 } & \multirow[b]{2}{*}{ 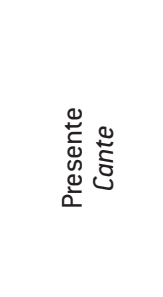 } & \multirow[b]{2}{*}{ 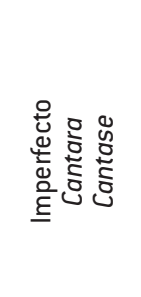 } \\
\hline & & & 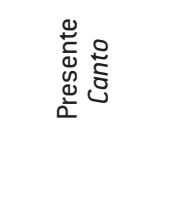 & 产竞 & 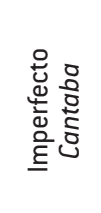 & 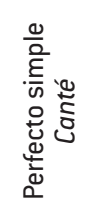 & & & \\
\hline
\end{tabular}

Nota. Tomado de Alarcos [1984].

Al respecto, se manera muy acertada, se cita a Coseriu (1977):

Las formas lingüísticas -no obstante lo constante y lo funcional- se dan en el hablar concreto y se aprehenden en el mismo mediante una intuición eidética simultánea con su comprensión como tal... Entre los dos planos no puede haber un perfecto paralelismo... Las formas del contenido de alguna manera, organizan toda la sustancia correspondiente... mientras que en la expresión la sustancia acústica se selecciona y buena parte de ella queda simplemente no formada. (p. 118)

López García señala que hay una necesidad de los tiempos del paradigma del español, en virtud de sus particularidades, y expone ideas clave como las siguientes. 
En cuanto a acciones nada puede distanciar a la enunciación del enunciado, porque cada enunciación pone un enunciado -lo enuncia-que es coetáneo con ella.

Si se adopta el punto de vista de la situación o momento del habla, o del sujeto, nos encontramos con la posibilidad de situaciones distintas y con la necesidad de actantes diferenciados: si se parte del acto y de su producto, resulta que el enunciado es lo enunciado por la enunciación y uno y otro son necesariamente coetáneos. En el lenguaje no hay enunciación sin enunciado, ni enunciado sin enunciación.

En español se privilegia la coherencia temporal para el establecimiento de los distintos tiempos, la expresión del hablante y la del cohablante no es necesaria en los paradigmas de la conjugación: español hablo vale por el inglés I talk (nunca talk*); español hablas por inglés you talk (nunca talk*); solo habla no nos dice cuál es el agente, precisamente porque en el sistema de diálogo no hay nada que lo represente, y así necesitamos Juan habla y María habla. En plural sucede lo mismo: los plurales internos que incorporan yo y tú pueden prescindir del agente -hablamos, habláis-, pero el plural externo nunca —ellos hablan, ellas hablan-, y cuando lo hace el resultado es la impersonalidad, casi la pura raíz verbal —dicen que lloverá como ¡vivir para ver!—.

Así, López García presenta el paradigma morfológico del presente en español (p. 122): (véase tabla 9).
Tabla 9

Paradigma morfológico del presente es español

\begin{tabular}{|c|c|}
\hline & hablo \\
\hline & hablas \\
\hline él/ella & habla \\
\hline & hablamos \\
\hline & habláis \\
\hline ellos/ellas & hablan \\
\hline
\end{tabular}

Nota. Tomado de López [2005].

Opina que por eso no se puede aceptar la existencia de sincretismos en el copretérito del indicativo y en otros tiempos: yo hablaba es enfático, lo normal es hablaba, que como primera persona se enfrenta a la forma no enfática María hablaba, por ejemplo.

Esta imbricación del hablante y del cohablante en la raíz verbal tiene una importante consecuencia: como la enunciación viene a coincidir con el enunciado en el presente, a partir de él, el pasado y el futuro se constituyen como extrañamientos de ciertas partes de la enunciación-enunciado respecto a la totalidad, enunciado respecto a la totalidad, antes que enunciados anteriores o posteriores, pues en realidad el punto de referencia, si no se expresa, se difumina.

En un sistema de coherencia temporal el único tiempo propio es el presente, y por eso resulta ontogénicamente también el primero. El sistema del español está edificado sobre el presente (véase figura 3).

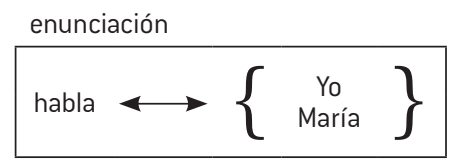

\begin{tabular}{|l|l|}
\hline \multicolumn{2}{|l|}{ enunciación } \\
\hline $\begin{array}{l}\text { Sujeto del } \\
\text { enunciado }\end{array}$ & $\begin{array}{l}\text { Predicado del } \\
\text { enunciado }\end{array}$ \\
\hline
\end{tabular}

enunciado 
Aquí la acción de la enunciación coincide en el tiempo con la del enunciado: como enunciación, le enunciación-enunciado es atribuida a Yo (sujeto de la enunciación); como enunciado, la enunciación-enunciado es atribuida a María (sujeto del enunciado). Cuando el sujeto del enunciado es yo, y el sujeto hablante naturalmente es YO, el esquema anterior del presente se transforma en lo que muestra la figura 4:

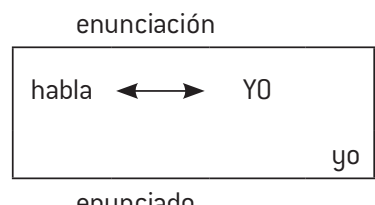

enunciado

FIGURA 4. Transformación del Yo. Adaptado de López (2005).
Con un índice Yo que lleva a la enunciación, y a través de ella al tiempo-modo-aspecto (al momento del habla y a quien enfoca lo dicho), y un índice yo, formalmente idéntico al anterior, que lleva al enunciado, y a través de él al número y la persona del sujeto.

López García también explica cómo obtener el pasado. Según se había dicho, habló, en la medida que representa una enunciación-enunciado, no puede situar su enunciado discriminándolo completamente de la enunciación que lo crea (en otros términos, la proposición del referente sí es independiente, el enunciado no). La lengua resuelve la contradicción usando los respectivos sujetos de la enunciación y del enunciado, y procediendo a desligar el sujeto del enunciado del sujeto de la enunciación, aunque el enunciado en cuanto tal siga estando vinculado a su enunciación (véase figura 5).

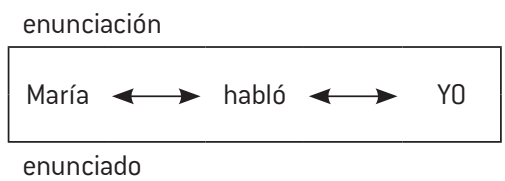

PASADO

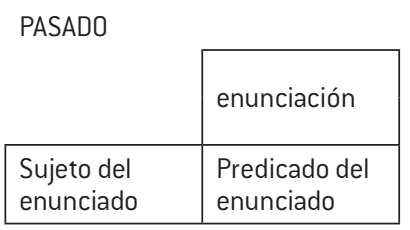

FIGURA 5. El pasado. Tomado de López (2005).

La autonomía del pretérito, cuando se le compara con el presente en el sistema de coherencia temporal, aparece claramente manifestada en español por su paradigma específico: hablél aste/él, ella -ó/ -amos/-asteis/ ellos, ellas -aron. Nótese que se trata de una serie de desinencias personales distintas de las del presente porque la persona del sujeto del enunciado ha sido extrañada respecto al YO de la enunciación.

Al explicar cómo obtener el futuro, opina que el ser humano, como ser temporal, tiene historia, pero no tiene futuro. ${ }^{5}$ Todo rema lleva a infor-

5 El autor del presente trabajo acepta tal planteamiento si con él se quiere expresar que en el futuro los eventos no se han producido todavía. mación implícita o explícita anterior, pero no puede afirmarse si el tema suscitará continuaciones o dejará de hacerlo. Es realmente posible un valor de futuro en el sistema de coherencia temporal del español, pero no a base de extrañar el sujeto del enunciado en el presente y mucho menos practicando un posible extrañamiento del predicado, pues forma una unidad insoluble con la enunciación, sino abriendo la posibilidad de un segundo predicado que se añada al anterior.

El comportamiento de los sujetos y de los predicados es asimétrico: mientras que dos sujetos contradictorios nunca pueden ser adscritos simultáneamente a un mismo predicado, la reciprocidad no es cierta, y tenemos que 
dos o más predicados que se contradicen pueden completar un mismo sujeto - ${ }^{*}$ la mujer y el marido son varones, pero la bandera es blanca y negra-. Es lo que sucede cuando nos servimos del presente con valor de futuro. Cuando un verbo se compone de proceso + resultado, es decir, cuando insinúa una dualidad predicativa implícita, resulta factible reservar el proceso, que está teniendo lugar ahora, para el predicado presente y proyectar su resultado hacia el predicado futuro, esto es, Juan trabaja como Juan hace PRESENTE un trabajo FUTURO.

Los tres valores de coherencia temporal que se han considerado hasta ahora no se establecen en un plano de igualdad. Ontogenética y también semiológicamente, lo primero es el presente y, solo a partir de él y como extrañamientos respectivos del sujeto y del predicado, se forman el pasado y el futuro. Si ahora se indujese nuevamente un extrañamiento de segundo orden relativo a los dos tiempos, obtendríamos el pasado ampliado hablaba a partir de habló, y el futuro retrocedido hablaría a partir de hablará. Ambos tiempos son paralelos y cruzados.

Cuando en el pasado habló, que ha sido obtenido a base de extrañar el sujeto del enunciado, se introduce un segundo predicado mediante la partición del primitivo predicado en proceso y resultado, se llega a hablaba; es decir, a un tiempo cuyo sujeto se sitúa separado del momento de $\mathrm{YO}$, pero cuyo predicado puede ampliarse desde el sujeto hasta YO, y de ahí los frecuentes matices durativos (véase figura 6).

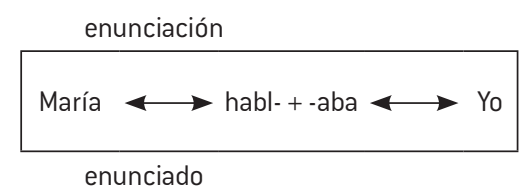

FIGURA 6. El copretérito. Tomado de López (2005).
Como en el caso del futuro, se insinúa la tendencia a que la parte procesual, señalada por los morfemas flexivos, sea adscrita al sujeto de la enunciación y la parte rectiva, marcada por el lexema, dependa más bien del sujeto del enunciado.

La peculiar situación de hablaba en el sistema de coherencia temporal insinúa algunos valores que hallan su manifestación plena en los sistemas discursivos de la temporalidad y de la actualidad. Así, hablaba es un pasado ampliado, es decir, un pasado como habló, pero alargado potencialmente hasta el momento presente ¿qué hacías? escribo una carta... e incluso más allá en el copretérito llamado de conatu y construcciones similares -le dio un dolor tan fuerte que se moría: hoy está mejor; hacía falta otro plan de estabilización para arreglar la economía nacional-.

También sus valores de temporalidad copretérito y de actualidad inactual resultan de lo anterior. Es un pretérito por el distanciamiento del sujeto del enunciado respecto al sujeto de la enunciación, pero también un presente de conatu, por la diferenciación del proceso y del resultado en el seno del verbo; se trata de un presente del pasado o copretérito. Su inactualidad deriva, al mismo tiempo, de la figura 6, ya que la máxima actualidad inducida por el solapamiento del YO y del sujeto del enunciado se encuentra doblemente debilitada por la separación del sujeto del enunciado que impone el pasado y por la bipartición del predicado con el consiguiente alejamiento añadido del resultado. Es importante destacar que los sistemas basados primariamente en la actualidad no pueden explicar "cómo es posible que habló" se use en narraciones con valor inactual, o "hablaba" por referencia al mundo comentado con valor actual. Según se desprende de lo dicho, hablo/habló/hablaba es una terna que va de la máxima actualidad a 
la máxima inactualidad, pero sin que ninguno de ellos tenga que ser relegado a la expresión de uno solo de los matices.

Cuando en el futuro hablará, que ha sido obtenido a base de diferenciar el proceso del resultado y extrañar dicho predicado interno en el seno del verbo, introducimos además el distanciamiento de los respectivos sujetos de la enunciación y del enunciado, se llega al valor hablaría, que es un futuro retrocedido, o sea, un tiempo originariamente futuro al que luego se le busca un inicio (un sujeto del enunciado) anterior (véase figura 7).

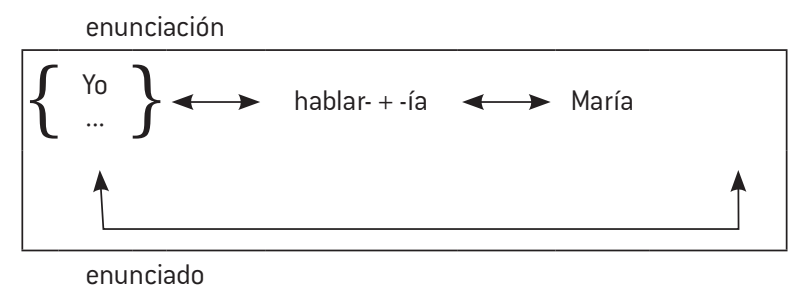

FIGURA ?. El pospretérito. Tomado de López (2005).

Se ha discutido mucho si hablaría debe ser considerado como un tiempo o como un modo. ${ }^{6}$ En el esquema de la figura 8 hablar- queda vinculado al sujeto de la enunciación $Y O$, en tanto el conjunto de morfemas del proceso de actualización -ría se aproxima al sujeto del enunciado María. Tenemos así un Yo que, lejos de sostener la enunciación, soporta el enunciado, es decir, un Yo pasivo o yo hermenéutico que, privado de la posibilidad de actuar, se limita a evaluar. En otras palabras, es un YO modal, y hablaría un tiempo que, como afirma la gramática tradicional, expresa una actitud mental del hablante ante los hechos que enuncia. Pero esta tendencia modal no es necesaria: como de otra parte de la enunciación, manifestada por los morfemas flexivos de actualización, también está ligada indirectamente a dicho YO, podemos hacer

6 Ajuicio de muchos gramáticos, este aspecto ya fue resuelto por Bello. prevalecer el puro matiz temporal, con lo que se obtienen valores no modalizados de dicha forma: -dijo que vendría.

El tratamiento habitual de hablaba como correlato de habló y el de hablaría como correlato de hablará queda asegurado al confrontar los esquemas: según López García, hablaba es un pasado ampliado y hablaría un futuro (hipotético) ampliado hacia atrás o futuro retrocedido, por lo que hablaba sustituye a habló en ciertos contextos — se levantó, se duchó, desayunó, y a las 8 cogía el tren para Barcelona-, y hablaría sustituye a hablará - tu no llevarías el coche, yo traería la merienda-. Antonio cuidaría de las bebidas. Pero al mismo tiempo hablaba, un extrañamiento del sujeto del enunciado completado con un extrañamiento del predicado interno, y hablaría, un extrañamiento del predicado interno completado con el extrañamiento del sujeto del enunciado, están muy próximos. Así, se da la paradoja de que hablaba, formado sobre habló, y hablaría, formado sobre hablará, alternan con frecuencia - quería/querría pedirte un favor, no pasaba/pasaría nada grave si no viniese-, en tanto que sus respectivos orígenes, el pasado de habló y el futuro de hablará, no se sustituyen mutuamente sino en circunstancias muy excepcionales (en el yo me fui chileno). Obsérvese, además, que la habitual definición de hablaría como futuro del pasado en el sentido de futuro medido desde el pasado no da cuenta de expresiones como sería bueno multiplicar los créditos, que se originan en el presente y van hacia el futuro: hablaría no es un futuro desde el pasado, sino un futuro hacia el pasado, es decir, un futuro cuyo origen se busca antes, ya en el presente, ya en el pasado.

Estas dos percepciones de hablaba y hablaría solo dan cuenta de sus significados fundamentales de lengua, no de los valores discursivos de estos tiempos, para lo cual hay que acudir a la temporalidad y a la actitud temporal: hablaba supone una anterioridad del 
sujeto del enunciado a la enunciación, pero al mismo tiempo un acercamiento a dicho momento derivado del desarrollo que se larga potencialmente, de ahí su oposición aspectual a habló. Hablaría supone un alargamiento del proceso predicativo hasta un resultado posterior, pero subsidiariamente una retrocesión del sujeto del enunciado, que puede situarse en el presente o en el pasado.

En su libro Gramática cognitiva para profesores de L2, López García (2005) aborda la misma problemática desde la perspectiva de la gramática cognitiva, e integra las tres visiones al tratar de exponer el papel del verbo en la oración. De igual forma, ofrece una explicación acerca de la ventaja de la representación visual para comprender las diferentes categorías gramaticales, entre ellas el verbo. Llama al aspecto (a juicio del autor de este trabajo se refiere al aspecto léxico) dinamismo durativo y lo diferencia del tiempo, al que define como dinamismo orientativo, que representa el paso del tiempo, el cual supone un desarrollo pasado o futuro para el concepto verbal. El punto de referencia de la orientación, y en esto coincide con todas las teorías analizadas, es el momento del habla.

Acerca del aspecto y las diferentes lenguas, dice que existe una coincidencia fundamental entre estas, mientras que en el dinamismo orientativo, es decir, el tiempo verbal, se manifiestan marcadas diferencias. Añade, además, que hay otra clase de dinamismo en el que no coinciden las lenguas y que llama el dinamismo de enfoque, o sea, el modo.

Compara al verbo con el nombre, ${ }^{7}$ porque ambos necesitan determinantes. En el caso del sustantivo, son los que se orientan hacia el hablante (demostrativos); los que se orientan hacia las personas del diálogo (posesivos)

7 Sustantivo. o se orientan hacia lo dicho y al decir al mismo tiempo (relativos). En el caso del verbo, son el tiempo, el modo y el aspecto (López García 2005, p. 148):

1. El tiempo (al igual que los demostrativos) orienta la oración respecto al momento cuando el hablante la enuncia. El tiempo verbal sitúa la oración respecto al AHORA, al momento del yo hablante.

2. El modo (al igual que los posesivos) orienta la oración en relación con las personas del diálogo entre las que interactúa. El modo verbal sitúa la oración en lo referente a las PERSONAS YO-TÚ.

3. El aspecto (al igual que los relativos) orienta la oración no solo en cuanto al yo, sino también respecto al mundo exterior en el que dicho yo está integrado. El punto de referencia del aspecto verbal es, pues, el AQUí.

Explica López García que los límites entre los determinantes verbales (y, por ello, los oracionales) se manifiestan borrosos. Por ejemplo, el pretérito del subjuntivo puede valer como el pretérito del indicativo: Abel Matutes, el que fuera (= fue) ministro de Asuntos Exteriores..., y al contrario, el futuro del indicativo vale como subjuntivo de probabilidad en serán las diez por son las diez. Tampoco es infrecuente que un mismo matiz aspectual se pueda expresar con el empleo de verbos léxicos o con tiempos verbales: la diferencia entre lo puntual y lo reiterativo de picar frente a picotear reaparece en un mosquito lo picó en la pierna frente a siempre que se acercaba a la charca lo picaba un mosquito en la pierna.

Sin embargo, el autor analiza cada categoría por separado. Lo que interesa en este trabajo es su visión acerca del tiempo verbal, que se refiere a continuación. 
Señala que el verbo orienta la oración ${ }^{8}$ respecto al momento del habla y la sitúa antes, después o al mismo tiempo, pero indica que esta idea es insuficiente porque en español, y en la mayoría de las lenguas, hay más de tres tiempos.

Así, presenta dos maneras de aumentar las posibilidades expresivas (2005):

a. Aumentar el número de índices con la introducción de índices secundarios. Es lo que se suele hacer en la manera informal de situar los sucesos, en lo que se pudiera llamar calendarios informales. Por ejemplo: eso fue antes de que nacieras, pero después de que viniéramos a vivir a Madrid. El sistema se presenta en la figura 8 así:

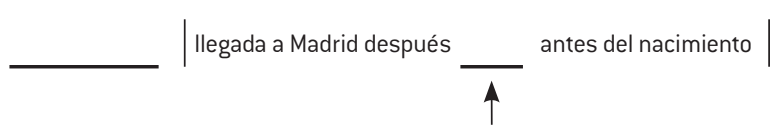

FIGURA 8. El sistema. Tomado de López (2005).

b. Especificar la distancia exacta entre un único índice, que es lo que hacen los calendarios formales; por ejemplo, año 6 d.J.C. quiere decir exactamente que han pasado seis años desde el nacimiento de Jesucristo (véase figura 9).

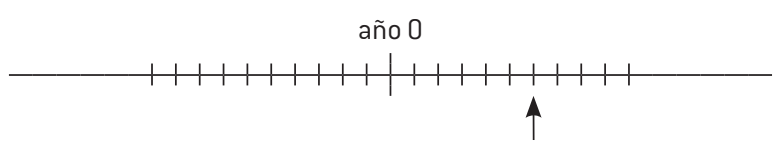

FIGURA 9. El procedimiento a para especificar la distancia. Tomado de López (2005).

El procedimiento a) o de los índices secundarios es fácil de plasmar en el lenguaje, basta con situar el desarrollo de una oración ${ }^{9}$

8 El autor centra sus análisis en el marco de la oración. A juicio del autor del presente trabajo, muchas de sus apreciaciones son aplicables al enunciado, más allá de los límites oracionales.

9 Este tipo de oración pueda denominarse también oración gramatical o cláusula. respecto al desarrollo de otra oración. Cuando llegaron, ya habian desayunado, esto es (véase figura 10):

I
ya habían desayunado $\uparrow \quad$ cuando llegaron

FIGURA 10. Los índices secundarios. Tomado de López (2005).

Según López García, se trata de un sistema de marcación de referencias temporales muy cómodo de expresar y que existe en todos los idiomas de modo parecido. Sin embargo, precisa que a veces los índices secundarios tienen que expresar referencias terminadas en el pasado o que se terminarán en el futuro, pues, en caso contrario, los eventos principales no podrían anclarse con exactitud.

Es algo parecido a lo que sucede con los calendarios informales: si se dice vendremos después de San Lorenzo (festividad católica que se celebra el 10 de agosto), se tiene claro que llegarán después del 10 de agosto, pero si se dice vendremos después de la siega, no se da referencia clara porque la siega puede acabar en cualquier día del verano, en julio o en agosto. Por otro lado, el orden de los sucesos no es indiferente: después de comer pescado, cayó enfermo permite suponer que el pescado estaba en mal estado y fue la causa de la enfermedad, pero cayó enfermo y comió pescado da a entender que la dieta del enfermo incluía el pescado.

Para que no haya ambigüedad, el tiempo de la oración con la que expresamos el índice secundario debe significar un desarrollo acabado, es decir, un aspecto terminado, lo cual permite situar la oración que lleva el índice principal con entera seguridad. Como puede observarse, aunque López García se está refiriendo al tiempo verbal, no puede soslayar la aspectualidad, porque en no pocas ocasiones esta incide en la selección que debe hacer el hablante del tiempo verbal para producir el enunciado. 
Luego, precisa que el procedimiento b) no se sirve de índices secundarios, sino que toma como única referencia el momento del habla. Entonces, se pregunta: ¿cómo es posible que existan dos pasados (vine y venía) y dos futuros (vendré y vendría)? Y se responde que la razón estriba en que lo normal es la coincidencia entre el acto de decir y lo que decimos, entre la enunciación y el enunciado, por cuanto que "cualquier distanciamiento del enunciado respecto de la enunciación supone una violencia de dicha situación natural" (2005, p. 151; véase figura 11).

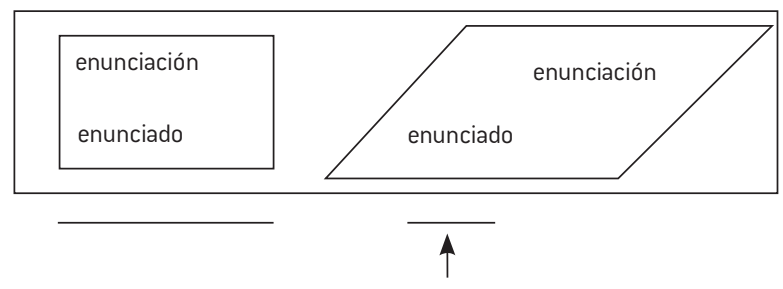

FIGURA 11. El procedimiento b. Tomado de López (2005).

La coincidencia entre la enunciación y el enunciado, entre el decir y lo dicho, se da en el tiempo presente. A juicio de López García, es esta la razón por la cual los niños solo usan el presente en los primeros años de vida y, también, la causa de que los que aprenden una segunda lengua al principio solo se sirven del presente.

Pero el ser humano puede separar la enunciación, que es siempre presente, del enunciado, que puede ser presente, pasado o futuro.

Para acercarnos a una imagen visual de la existencia de más de un pasado o más de un futuro, el autor representa el fenómeno así (véase figura 12):

Imaginemos una cuerda fijada al techo con una bola en el extremo; así se obtiene un péndulo. En la posición de reposo, el punto del que cuelga y la bola en la que termina están en la misma vertical. Pero si haciendo una fuerza separamos la bola de la vertical y la soltamos, entonces el péndulo echará a andar porque dicha bola tiende a recuperar la posición de reposo, aunque, como sabemos, no lo logrará inmediatamente, sino que rebasará dicha posición, luego volverá atrás a rebasarla, y así sucesivamente. (2005, p. 53)

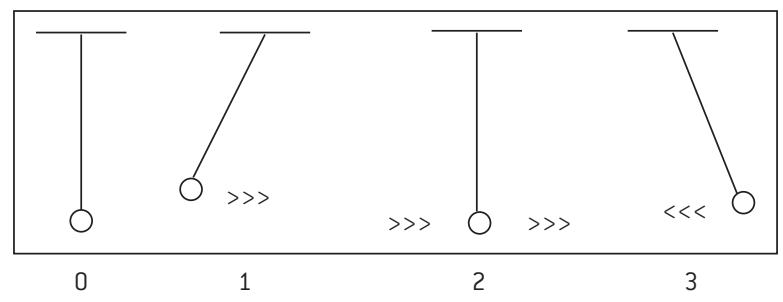

FIGURA 12. Imagen visual de más de un pasado y más de un futuro. Tomado de López [2005].

López García explica que el péndulo ejemplifica tres posiciones básicas con relación a lo que todavía no es un péndulo, sino una simple bola colgada de una cuerda, es decir, la posición de reposo 0:

1: Es la anterioridad a la vertical, esto es, el pasado.

2: Es la coincidencia con la vertical, esto es, el presente.

3: Es la posterioridad a la vertical, esto es, el futuro.

Pero un péndulo es un sistema dinámico y entre 1 y 2 existen muchos puntos intermedios, como también entre 3 y 2. Los puntos intermedios comparten con 2 la propiedad de venir de un lado e ir hacia otro; por lo tanto, no son puntos extremos, aunque difieren de 2 al no coincidir con la vertical: se puede llamar 4 al conjunto de los puntos que viene de 1 y van a 2, y 5 a los puntos que vienen de 3 y van a 2 . Así se obtendría una visión más realista del péndulo:

Este sistema describe el funcionamiento de los tiempos simples del modo indicativo del español, como se representa en las figuras 13 y 14. 


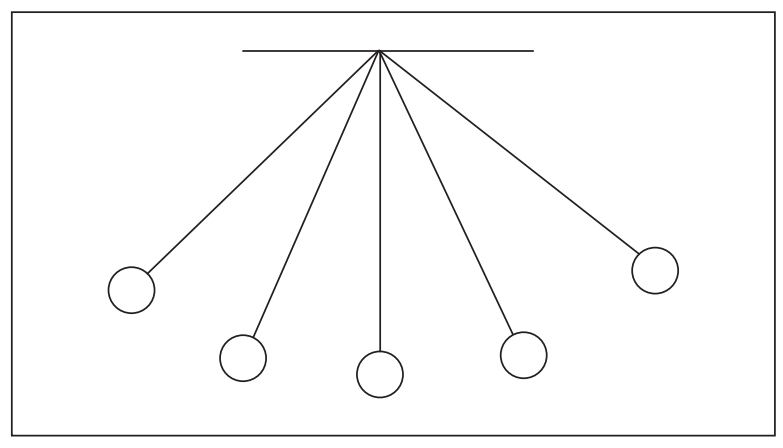

$1>4>2<5<3$

FIGURA 13. Funcionamiento de los tiempos simples. Tomado de López (2005).

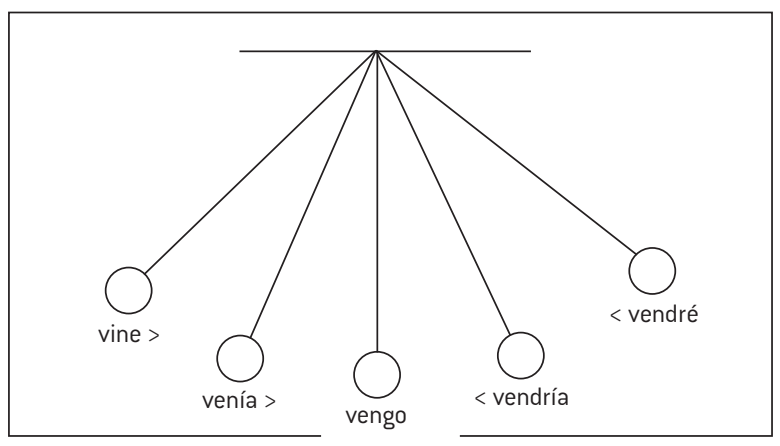

FIGURA 14. Funcionamiento de los tiempos simples. Tomado de López (2005).

Según el esquema de la Figura 14, el pretérito significa un enunciado cuyo mundo referido no coincide con el momento de la enunciación, pero, además, un pasado que, por no concebirse en movimiento, es absoluto, que no camina hacia la posición de equilibrio del presente. Como el movimiento pendular puede iniciarse separando la bola del péndulo mucho o poco de la vertical, no se dice si el pasado es muy lejano o muy cercano. Esta forma sirve en español indistintamente para eventos del pasado (Colón llegó a América en 1492), para los que no están muy lejos (Ayer tuve un disgusto) e incluso, para los que casi rozan el presente (como Al fin llegué dicho por una persona que acaba de descender del avión).

El pasado ampliado (copretérito) camina hacia el presente y viene de un pasado anterior.
De ahí que esa forma signifique transcurso o desarrollo: la diferencia entre de niño, tenía perro y de niño, tuve perro es que la posesión del perro se ve en su desarrollo en el primer caso, pero no en el segundo; por eso, se puede añadir una expresión que marque dicho desarrollo con tuve (de niño tuve perro durante dos años), pero no con tenía ('de niño tenía perro durante dos años), pues sería redundante. A juicio del autor de este trabajo, López García ha unido en la misma explicación los valores temporal y aspectual del copretérito, difícil de separar cuando se trata de explicar los usos de este tiempo verbal.

Para el autor el equivalente del pretérito vine es el futuro vendré, el cual significa un enunciado cuyo mundo referido no coincide con el momento de la enunciación. Sin embargo, no son formas paralelas, pues el ser humano es un ser histórico que tiene memoria del pasado, pero que encuentra muchas dificultades para imaginar el futuro. Entonces, lo representa como se muestra en la figura 15.

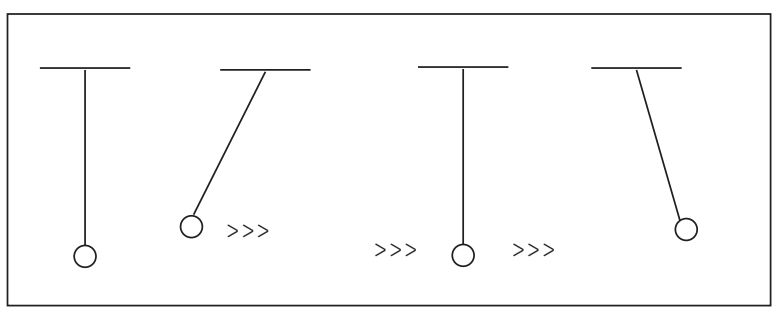

FIGURA 15. Pretérito y futuro. Tomado de López [2005].

Este modelo se asemeja más al péndulo real, que pierde progresivamente amplitud en el periodo de su oscilación a causa del rozamiento.

El otro futuro del español es el futuro retrocedido (pospretérito), es decir, una forma que, aunque mirando a un punto futuro, camina hacia el pasado: vendría.

En resumen, según López García, en español el conjunto de los tiempos verbales se organiza sobre tres parámetros: el de la coherencia 
temporal, que se orienta en relación con la enunciación y su desarrollo; el de la temporalidad, que se orienta según su condición deíctico-temporal, y el de la actitud temporal, que lo hace respecto a un ingrediente subjetivo. YO es a la vez el sostén de un proceso, el del momento cuando se da, y el de la persona que lo realiza, y correlativamente el tiempo del verbo se valorará como coherencia temporalidad, como temporalidad o como actitud temporal.

Para López García no tiene sentido afirmar que el sistema es de coherencia temporal, o de temporalidad, o de actitud temporal. En realidad, es de coherencia temporal y de temporalidad y de actitud temporal, de forma que cualquier variante morfológica realizada en el discurso participa de los tres parámetros (véase figura 16).

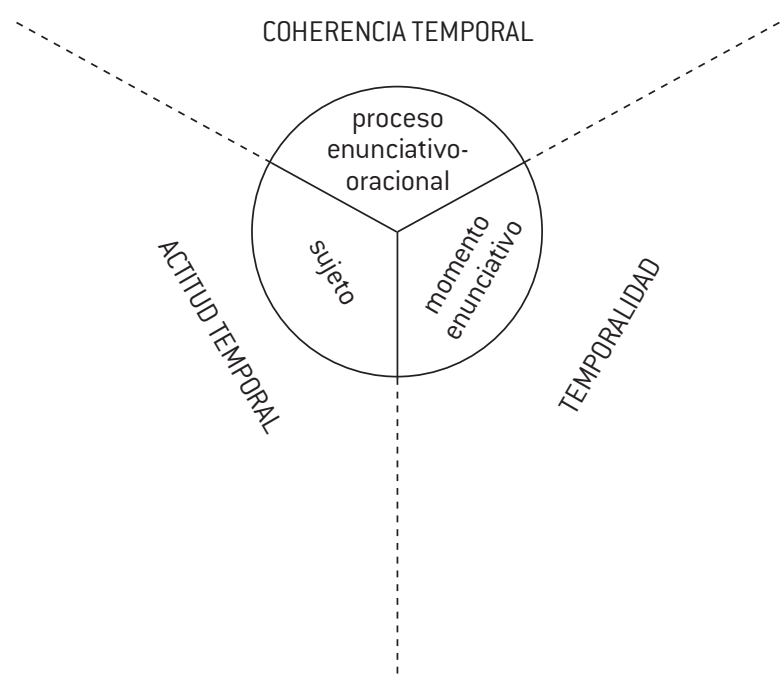

FIGURA 16. Parámetros del sistema. Tomado de López (2005).

No obstante, según los propósitos de este trabajo, el ángulo de interés fundamental es el de la temporalidad, puesto que se caracterizarán los significados parciales de la anterioridad en relación con el momento del habla en el español y cómo se expresan en la variedad cubana.

\section{Luquet: los tiempos y los modos}

En su trabajo La teoría de los modos en la descripción del verbo español. Un nuevo planteamiento, Gilles Luquet ofrece una visión aparentemente novedosa de esta problemática, pero en realidad lo que hace es integrar puntos de vista sostenidos con anterioridad por otros autores. A juicio del autor de este trabajo, el interés fundamental de Luquet se halla en la importancia que da al vínculo entre significado y significante, y a la primacía que concede al análisis de los significados y significantes en el contexto. Además, fundamenta su análisis en que el significante lingüístico merece una especial atención en el análisis gramatical, y considera que las gramáticas españolas ilustran la tendencia a privilegiar la descripción del significado lingüístico, y no la del significante, al que pretendió dar prioridad en este material.

Sobre la unicidad del signo, señala que se debe admitir que en la organización del sistema verbal español la homonimia no existe y, por lo tanto, el significado que se debe relacionar con una forma verbal es único, es decir, idéntico a sí mismo en todas las ocurrencias de esta forma. Según el autor, lo que aporta un significante verbal a la construcción de un enunciado es invariable: una forma verbal contribuye con el mismo significado a la construcción de todos los enunciados en los que aparece, y lo hace independientemente de la sintaxis que le afecta y de la situación de experiencia que esta evoca.

Como ejemplos ofrece lo siguiente:

No hay que suponer dos valores distintos para la forma verbal pronunciara:

(1) Se comenta el discurso que anoche pronunciara el presidente (ejemplo tomado del Esbozo). 
(2) La sesión acabó sin que el presidente pronunciara el discurso anunciado.

En (1) se evoca una situación de experiencia en la que un discurso ha sido pronunciado, mientras que en (2) se evoca una situación en la que no hubo discurso, pero achacar esa diferencia a un invisible cambio de valor de pronunciara, elemento común en los dos enunciados, es menos natural —es decir, es menos sencillo- que postular que en la potencialidad de la lengua, esa forma tiene un valor que la hace compatible con la representación del acontecimiento real expresado en (1) —no solo en ella sino por todo un conjunto de elementos contextuales-y con la representación del acontecimiento irreal expresado en (2), gracias a otro conjunto de elementos contextuales. Para Luquet, la tarea de la lingüística consiste en explicar esa compatibilidad.

Para referirse al sistema verbal español adopta la distinción establecida por Maurice Molho entre un sistema verbal conjugante y un sistema verbal conjugable (y conjugado). Se considerarán conjugantes las representaciones que configuran el significado temporal y modal del verbo, y conjugables las representaciones que suelen incluirse en las categorías gramaticales de aspecto y de la voz. En función de esta distinción, admite que la descripción morfológica del verbo se limita a la de sus formas propiamente flexivas — sus formas simplesy que el estudio de las formas compuestas por tratarse de perifrasis verbales- no pertenece a la morfología sino a la sintaxis. Esta última consideración no es compartida en la presente investigación. Según la Nueva gramática de la lengua española (2010),

[...] en la tradición, se ha venido asignando los tiempos compuestos y las perífrasis a dos clases distintas, en razón sobre todo del diverso grado de integración entre sus componentes. En primer lugar, los tiempos compuestos rechazan la concordancia con los participios, a diferencia de las perífrasis:
Las \{tengo *he\} escritas. En segundo lugar, algunas perífrasis imponen restricciones semánticas a los predicados y a los sujetos con los que se forman, mientras que los tiempos compuestos pueden construirse con cualquier verbo y no limitan sus posibles sujetos. No existen, pues, verbos que carezcan de tiempos compuestos (salvo la excepción, solo parcial, de soler). (p. 536)

No todas las formas simples del verbo tienen la misma función: algunas son predicativas, otras no; algunas proporcionan una información (aporte de significación) sobre algo o alguien (soporte de significación), otras, en cambio -las que la tradición califica de imperativas-, no sirven para predicar de nada ni de nadie. Son formas que, de hecho, no pertenecen al mismo sistema de las demás, ya que su capacidad funcional se limita a la expresión de las modalidades de la enunciación. Si se admite, pues - como suele decirse hoy día-, que modo y modalidad son categorías gramaticales distintas, no se pueden tomar en cuenta las formas imperativas del verbo español en una descripción de sus modos morfológicos.

Para Luquet, los modos son los que permiten describir las formas predicativas del verbo y postula que un modo no puede definirse independientemente de una determinada representación de tiempo y de persona. Para ilustrar la interdependencia analiza de forma sucesiva las relaciones que existen entre modos y tiempo, y entre modos y persona. Sobre modo y tiempo, explica que una de las propiedades del verbo, en las lenguas indoeuropeas, es que conlleva una doble representación del tiempo. El verbo, por decirlo en términos guillaumianos, no solo "im-plica" el tiempo, también lo "ex-plica”. Lo "im-plica” porque lleva consigo la representación de un acontecimiento en el sentido más general de la palabra ${ }^{10}-\mathrm{y}$

10 "Acontecimiento" es un término que se usa aquí para aludir a cualquier "experiencia" que se inscribe en el tiempo y a la que pueden asignarse un comienzo y un fin. 
porque un acontecimiento, en el sentir de un actor de lenguaje, es algo que se desarrolla en el tiempo. Es algo, que por tener una duración, suscita la representación de un tiempo (t) comprendido entre un límite de comienzo y un límite de fin. Pero esta duración, precisamente porque tiene límites, suscita a su vez la representación del tiempo (T) del que no es más que una porción. Suscita la representación del tiempo -ya no "im-plicado", sino "explicado"- en el que se describe el acontecimiento. Esquemáticamente sería como se muestra en la figura 17:

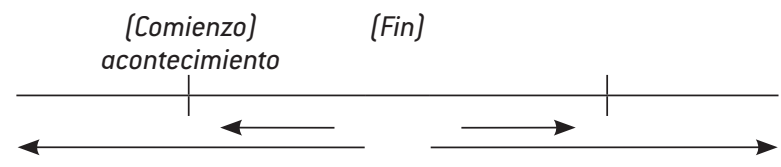

FIGURA 17. Representación del tiempo. Tomado de Luquet (2004).

El verbo español es, entre otras cosas, un doble sistema de representaciones del tiempo. Consta efectivamente de:

- Un subsistema de formas no personales (infinitivo, gerundio, participio) a las que corresponde una determinada representación de t, tiempo implicado por un acontecimiento (la naturaleza del tiempo en el que se inscribe dicho acontecimiento queda totalmente indeterminada dentro de ese subsistema).

- Un subsistema de formas personales a las que corresponde una determinada representación $T$ tiempo en el que se inscribe un acontecimiento (la naturaleza del tiempo implicado por dicho acontecimiento queda totalmente indeterminada dentro de este otro subsistema).

El primer subsistema, el que no implica la representación de la persona, es bastante fácil de describir.

Partiendo de un soporte temporal totalmente indeterminado, basta con atribuir a un instante cualquiera, el instante $t^{0}$, por ejemplo, el papel de instante de referencia y de ordenar, en relación con él, la serie de instantes que se sitúan en su anterioridad y en su ulterioridad inmediatas $\left(t-1, t-2 \ldots, t-n ; t^{+1}, t^{+2} \ldots\right.$, $\left.t^{+n}\right)$.

Elegir el instante $t^{0}$ como referencia y construir la representación de un acontecimiento que comprenda a la vez ese instante $t^{0} \mathrm{y}$, como mínimo, los instantes $t^{-1} \mathrm{y} \mathrm{t}^{+1}$, es describir el contenido de la representación de un gerundio (cantando; véase figura 18).

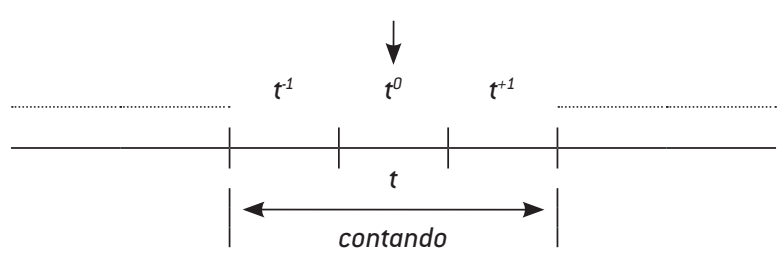

FIGURA 18. Representación del gerundio. Tomado de Luquet (2004).

Elegir el instante $t^{0}$ como referencia y construir la representación de un acontecimiento que comprenda el instante $t^{+1} \mathrm{y} n$ instantes de los que siguen $\left(t^{+2,}, t^{+3 \ldots}, t^{+n}\right)$ es describir el contenido de la representación de un infinitivo (cantar; véase figura 19).

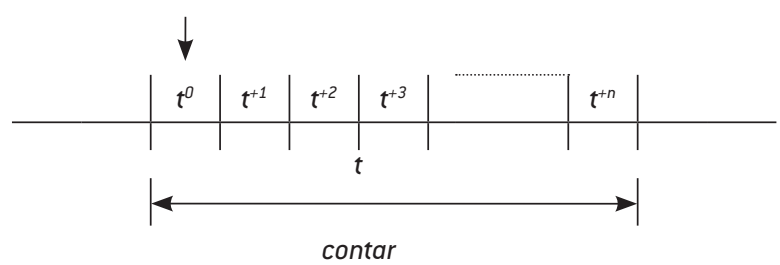

FIGURA 19. Representación del infinitivo. Tomado de Luquet (2004).

Elegir el instante to como referencia y construir la representación de un acontecimiento que comprenda el instante $t^{-1} \mathrm{y} n$ instantes de los que le preceden es describir el contenido de la representación del participio (cantado; véase figura 20). 


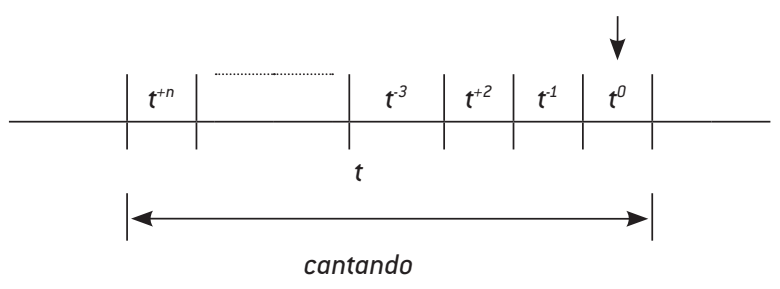

FIGURA 20. Representación del participio. Tomado de Luquet (2004).

En cuanto a las formas personales del sistema verbal y el tiempo, Luquet explica que las primeras son signos a los que corresponden diferentes representaciones lingüísticas del universo temporal de un Yo hablante. ${ }^{11}$ Son signos que permiten la localización de un acontecimiento en un tiempo lingüístico objetivado de diferentes maneras.

Existen en todas las lenguas indoeuropeas diferentes maneras de objetivar el universo temporal de un hablante, es decir, diferentes maneras de objetivar el tiempo lingüístico. En español, una de ellas es hacerlo a través del presente, es decir, a partir del lugar del tiempo -eminente singular- donde un Yo hablante se sitúa a sí mismo e inscribe su actividad. Asociado a la representación de lo que existe, el presente, en el universo temporal de dicho Yo se opone, por una parte, al pasado - lugar temporal de lo que ya no existe-y, por otra parte, al futuro -lugar temporal de lo que no existe todavía- Esquemáticamente se presenta lo anterior en la figura 21.

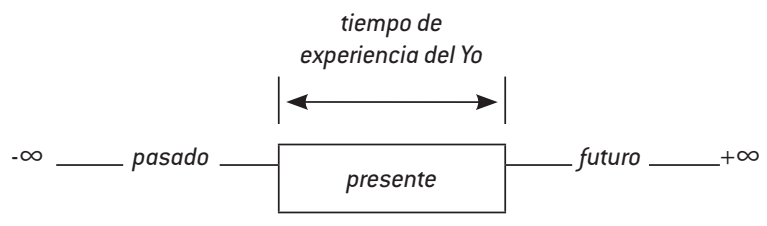

FIGURA 21. Manera de objetivar el universo temporal en español. Tomado de Luquet (2004).

El autor añade que, en un universo temporal, objetivado de tal manera, el presente,

11 El yo es a la vez el constructor y el utilizador del lenguaje. por definición, tiene una extensión subjetiva y variable y que ha de comprender, como mínimo, dos instantes de naturaleza distinta. El presente es el lugar del tiempo donde un instante de futuro se convierte continuamente en un instante de pasado: es lugar donde se funda, en el sentir continuo, la movilidad del tiempo. ${ }^{12}$ En la estructura semiológica del verbo español, la de cantar, por ejemplo, la representación de un acontecimiento asociado al presente es la que conllevan formas del tipo canto, cantas, canta, etc.; la representación de un acontecimiento asociado al pasado es la que llevan consigo las formas del tipo canté, cantaste, cantó, etc.; la representación de un acontecimiento asociado al futuro es la que conllevan las formas del tipo cantaré, cantarás, cantará, etcétera.

Pero la objetivación del universo temporal de un hablante puede tener otro punto de partida al de la representación del presente de experiencia. Puede tener como punto de partida, por ejemplo, la representación de un presente desconectado de cualquier experiencia del tiempo, o sea, la representación de un presente ficticio - un presente pura y simplemente imaginario- susceptible de coincidir o no con el presente de la enunciación. Por muy extraña que parezca, la representación de un presente de este tipo es la que supone la construcción tan ordinaria como Ayer, a las tres, llovía. Si se admite, en efecto, como suele hacerse, que llovía sume un valor de un presente del pasado, es decir, si evoca un acontecimiento que, para el autor del enunciado, tiene las propiedades de un presente (llueve) trasladado al pasado, hay que admitir también que un Yo hablante es capaz de concebir otro tipo de presente diferente al que le sirve para construir un enunciado. Es capaz de concebir un presente abstracto - un presente inactualizado- a partir del cual se determinan, en

12 En tiempo de experiencia de un hablante es el que transcurre, el que huye. Es un tiempo orientado de forma objetiva hacia el pasado. 
un universo temporal, un pasado y un futuro, igualmente inactualizados.

Lo anterior se evidencia, de manera esquemática, en la figura 22.

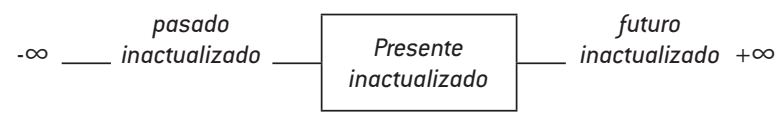

FIGURA 22. El presente inactualizado. Tomado de Luque (2004).

En la estructura semiológica del verbo español, la representación de un acontecimiento asociado a un presente inactualizado es la que conllevan las formas del tipo cantaba, cantabas, cantaba, etc.; la representación de un futuro inactualizado es la que conllevan las formas del tipo cantaría, cantarías, cantaría, etc.; en cambio, la representación de un acontecimiento asociado de manera exclusiva, en la potencialidad de la lengua, a un pasado inactualizado, no tiene significante: el pasado inactualizado no forma parte de las representaciones preconstruidas del tiempo del sistema verbal español.

Otra manera de objetivar el universo temporal de un hablante consiste en darle una forma simplemente bipartita, o sea, la forma de una extensión en la que un simple límite asociado al momento de la enunciación opone un espacio abierto a la actividad del Yo — un "presente futuro" indiferenciado- a un espacio cerrado a esa actividad.

Esquemáticamente se muestra en la figura 23.

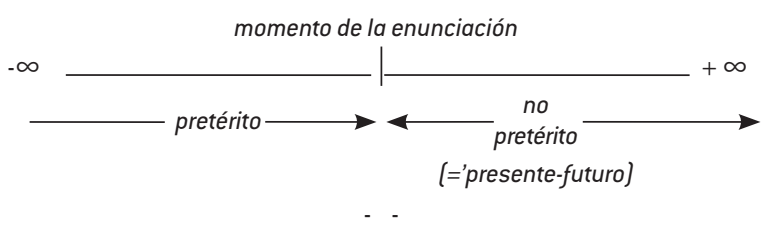

FIGURA 23. Presente futuro. Tomado de Luquet (2004).

En la estructura semiológica del verbo español —en su estado actual de definición-, la representación de un "presente-futuro" indiferenciado es la que conllevan las formas del tipo cante, cantes, cante, etc. En cambio, la representación del pretérito que se opone directamente a un "presente-futuro" así definido no tiene significante.

Una última manera de plasmar el universo temporal de un hablante consiste en no privilegiar ninguno de los elementos constitutivos; es la que radica en abstraer de este universo la representación de toda extensión singular e incluso de todo límite singular (véase figura 24).

$-\infty$

FIGURA 24. Representación sin límite. Tomado de Luquet (2005).

En la estructura semiológica del verbo español, la representación de este universo es la que conllevan dos series de formas: la serie cantara, cantaras, cantara, etc. Cantara y cantase son las formas personales del verbo que, en la potencialidad de la lengua, inscriben un acontecimiento en el marco temporal más abstracto que se puede concebir. ${ }^{13}$

Al abordar el tiempo lingüístico y el universo modal, señala Luquet que si se admite que las representaciones del tiempo lingüístico español son las que se acaban de describir, hay que admitir también que en el sistema verbal español no se oponen más que dos tipos de formas personales:

- Las que asocian la representación de un acontecimiento y su soporte personal a un universo formal directamente definido con relación al presente de experiencia (canto, canté, cantaré);

- Las que, a la inversa, asocian la representación de un acontecimiento y de su soporte

13 Lo que no significa, por supuesto, que al pasar de la lengua al discurso, es decir, al formar parte de un enunciado, una forma de tipo cantara o cantase no permita la localización temporal relativa de su contenido de expresión. Pero se trata de una localización obtenida por medios contextuales. 
personal a un universo formal no directamente definido con relación al presente de experiencia (cantaba, cantaría, cante, cantara, cantase).

Hay objeciones a que "cantaba" y "cantaría" estén incluidas en el mismo subconjunto que cante, cantara y cantase. No es muy difícil demostrar que cantaría no evoca verdaderamente el pasado, ni el presente, ni el futuro, pero ¿cantaba? ¿Por qué no considerarlo como un tiempo del pasado, como lo hacen prácticamente todos los gramáticos? ¿Por qué no incluirlo como canté en el subconjunto de las formas directamente definidas con relación al presente de experiencia? Porque sería confundir el tiempo que una forma verbal puede expresar en un enunciado y la representación del tiempo que está asociada a dicha forma en lengua.

Que sea posible expresar el pasado por medio de cantaba nadie lo duda; hay motivos, incluso, para pensar que es lo que más a menudo se hace con esta forma. Pero si cantaba es compatible con la expresión del pasado, no hay que olvidar que también es compatible con el presente e incluso con el futuro. Es lo que ilustran los siguientes ejemplos:

(3) Me dijeron que el plazo vencía hoy.

(4) Me dijeron que el plazo vencía mañana.

(5) Esta tarde había concierto, pero el pianista está enfermo (Alarcos Llorach, 1994, $\S 221)$.

(6) Se casaban el mes que viene, pero se oponen las familias (Alarcos Llorach, 1994, $\S 221)$.

(7) Yo que tú, me marchaba ahora mismo.

(8) Yo que tú, me marchaba mañana.

Dar por sentado que el imperfecto (copretérito) lleva consigo la representación del pasado — como se suele hacer- dificulta de forma considerable la explicación de su perfecta compatibilidad con adverbios o construcciones adverbiales del tipo hoy, esta tarde, mañana o el mes que viene.

En cada copretérito de los ejemplos (3) a (8), en cambio, no es difícil reconocer la representación de un presente inactualizado: la de un presente que ya no forma parte del universo de actualidad del enunciador.

Es cosa fácil de poner en evidencia en el caso de los enunciados (3) y (4), ya que se trata de dos ejemplos de discurso indirecto. En la anterioridad del día al que corresponde el hoy en: Me dijeron que el plazo vencía hoy, hay que reconstruir el enunciado del tipo: El plazo vence el día x. En este enunciado la expresión concreta el día x puede haber tomado la forma mañana, pasado mañana, dentro de tres días, dentro de cuatro días, etc., en función de lo que separa los dos enunciados en el tiempo cronológico.

De igual manera, en la anterioridad del día en que se inscribe el enunciado: Me dijeron que el plazo vencía mañana, hay que reconstruir un enunciado del tipo: El plazo vence el día $X+n$, en el que la expresión del día $\mathrm{x}+\mathrm{n}$ puede haber tomado también formas diversas (pasado mañana, dentro de tres días, dentro de cuatro días, etcétera).

Lo que tienen en común estos dos enunciados es que vencía, el copretérito que contienen, no es más que la reproducción de un presente (vence) inactualizado.

Son copretéritos casi idénticos los que tienen los ejemplos (5) y (6) (Esta tarde había concierto, pero...; Se casaban el mes que viene, pero...), - -ya que construir tales enunciados es declarar, en una especie e discurso indirecto libre, que ya no es posible validar los enunciados Esta tarde hay concierto o Se casan el mes que vieneya sean enunciados presupuestos, ya sean enunciados efectivamente pronunciados por 
alguien. Construir los enunciados (5) y (6) es declarar que se inactualiza del contenido de (5a) y de (6b):

(5a) Esta tarde hay concierto.

(6b) Se casan el mes que viene.

Parece que los copretéritos Yo que tú me marchaba ahora mismo o Yo que tú me marchaba mañana no tienen nada que los distinga en lengua de los que se acaban de analizar. Hay que considerar, en efecto, que los acontecimientos asociados a ahora mismo o a mañana están inactualizados por la condición de que dependen en sus enunciados respectivos; la condición irrealizable yo que tú. Me marchaba mañana es un enunciado que permite situarse en un presente no solo ficticio, sino también trasladado al más allá de su presente de experiencia.

Cuando se toma conciencia de lo que separa a un copretérito de un verdadero tiempo del pasado, del presente o del futuro, sería más fácil tomar conciencia de lo que hace de un pospretérito un futuro inactualizado y no un tiempo del pasado, del presente o del futuro.

Que sea imposible definirlo como un tiempo del pasado, del presente o del futuro, es lo que había comprendido Andrés Bello, que lo definía como un simple pospretérito. Pedro dijo que volvería es efectivamente un enunciado en el que es imposible localizar en relación con el presente de enunciación el acontecimiento significado por volvería: dijo que volvería /y volvió ayer/ y ahora vuelve/ y volverá mañana/. La única información temporal atribuible al pospretérito es que la 'vuelta' evocada se sitúa en la ulterioridad del pasado expresado por dijo. Volvería no es más que la representación inactualizada del futuro contenido en el enunciado del discurso directo: Volveré mañana.

Además, no es necesario acudir al discurso indirecto para reconocer un futuro inactualizado en cualquier empleo temporal del condicional. Construir un enunciado del tipo:
(9) Supo imponer a tiempo métodos de producción que harían de su empresa la primera de su sector.

Es evocar también un futuro desconectado del presente de actualidad: es construir la representación de un futuro inactualizado.

Un futuro inactualizado, por fin, es lo que se reconoce en los llamados empleos modales del condicional. En un enunciado del tipo:

(10) Si pudieras llegar media hora antes, nos daría tiempo a hacerlo todo.

Por ejemplo, se expresa un acontecimiento condicionado por otro, es decir un acontecimiento que es simplemente actualizable. Puede tratarse de un rodeo para pedir a alguien que llegue antes de lo previsto (Si puedes llegar..., nos dará tiempo a...) o de expresión de una verdadera improbabilidad, pero nada autoriza a decir que nos daría tiempo a expresa lingüísticamente una imposibilidad ${ }^{14}$ (lo actualizable abarca lo probable, lo improbable y lo simplemente posible).

En un enunciado del tipo:

(11) Según fuentes no gubernamentales, el tratado estaría a punto de ser firmado.

Se expresa una información en espera de confirmación, es decir, la representación de un acontecimiento que no es posible actualizar todavía en el momento de la enunciación. Se evoca un acontecimiento de actualización diferida.

No cabe duda de que en el marco de una sintaxis de modos habría que analizar otros muchos valores expresivos del imperfecto y del condicional, pero parece que los pocos ejemplos que se acaban de analizar son suficientes para sugerir que estas dos formas verbales tienen más puntos comunes con las formas cante, cantara

14 Solo el contexto o el cotexto permiten sugerir tal interpretación. 
o cantase que con las formas tipo canto, canté o cantaré. Tienen muchos más puntos comunes en las formas que permiten expresar lo hipotético, lo virtual, lo imaginario, lo supuesto, lo no experiencial, lo posible, lo probable, etc. Tienen muchos más puntos comunes con las formas que permiten simplemente inactualizar la representación de un acontecimiento.

No parece, según Luquet, totalmente disparatado postular que las formas personales del verbo español se reparten en dos subconjuntos modales: uno de ellos, de tipo actualizador, no comprende más que tres tipos de representaciones - canto, canté, cantaré- mientras que el otro, del tipo inactualizador, comprende cinco - cantaba, cantaría, cante, cantara, cantase.

Podría tratarse, desde luego, de un postulado más en la larga serie de las descripciones del verbo español, pero este tiene la particularidad de estar ratificado por la estructura de los significantes que pretende describir: está inscrito en los significantes de persona.

Al tratar los modos, los divide en modo no personal y modos personales, y abandona la tradicional oposición indicativo/ subjuntivo.

Para Luquet, en la organización semiológica del verbo español no existe, objetivamente, una morfología propiamente subjuntiva, como tampoco una morfología propiamente indicativa. Existe una línea divisoria objetiva entre formas no personales y formas personales y, dentro de estas últimas, una línea divisoria no menos objetiva entre los paradigmas que permiten distinguir una de la otra las personas $1 \mathrm{y}$ 3 y los que no lo permiten.

Se puede postular que existe en el verbo español:

- Un modo no personal que consta de tres unidades de representación: cantando, cantar y cantado.
- Un modo personal actualizador que consta de tres unidades de representación: canto, canté y cantaré.

- Un modo personal inactualizador que consta (en español contemporáneo) de cinco unidades de representación: cantaba, cantaría, cante, cantara y cantase.

Existen tres maneras de inactualizar la representación de un acontecimiento:

- Es posible inactualizarla considerando que ya no forma parte de la actualidad (cantaba).

- Es posible inactualizarla considerando que todavía no forma parte de la actualidad (cantaría).

- Es posible inactualizarla considerando que no tiene relación alguna con la actualidad (cante, cantara, cantase).

Según Luquet, lo que el hablante actualiza o inactualiza no corresponde exactamente a la vieja oposición entre lo real y lo irreal o entre lo experiencial y lo no experiencial.

(12) La República Árabe Saharaui Democrática (RASD) es el único país árabe aunque sea un Estado sin nación-que ha decretado el castellano como segunda lengua oficial.

Muchos motivos pueden incitar a la inactualización de un hecho real o experiencial. En conclusión, para Luquet el valor modal de una forma verbal está condicionado por la representación del tiempo que le está asociada en la lengua.

\section{Havu: la constitución temporal del sintagma verbal}

La imagen temporal que se percibe en una oración concreta es el resultado de la interacción 
de muchos factores, y para comprender los mecanismos que rigen la compatibilidad y la aplicabilidad de los diferentes elementos gramaticales a la hora de expresar verbalmente una situación real o presumible localizada en el tiempo, es imprescindible estudiar las relaciones entre ellas. Tal concepción es coherente con el fin del presente estudio; sin embargo, se presenta también un análisis con el que se pueden separar las dos categorías que tienen relación con el tiempo expresado por el verbo, el tiempo verbal y el aspecto (tiempo interno denotado por la forma verbal).

En su tesis La constitución temporal del sintagma verbal en el español moderno, Jukka Havu explica que la composicionalidad en el sintagma verbal se estructura en un sistema jerárquico. Señala que el término temporal significa en ese contexto esencialmente dos cosas:

a. Cada situación (o evento) tiene su propia estructura temporal interna.

b. Cada situación ha de poder localizarse en el tiempo (sea una situación real o conjetural). En el sentido amplio, lo temporal incluye también lo aspectual, concepto que para el autor significan los diferentes enfoques desde los cuales se puede visualizar una situación.

En el presente trabajo se considera que lo temporal expresado por el tiempo verbal y el tiempo interno del verbo son dos categorías que, aunque estrechamente interrelacionadas, conviene diferenciar en todos los análisis.

Aunque el estudio de Havu se concentra en todos aquellos instrumentos gramaticales que son operativos dentro del núcleo verbal, consideró necesario incluir en su análisis del verbo español los complementos adverbiales temporales y las oraciones subordinadas de tiempo, que son primordiales para comprender su funcionamiento. Estas últimas, aun siendo ajenas al núcleo verbal propiamente dicho, condicionan la aplicabilidad de varias categorías verbales y configuran los diferentes niveles de la aparición de la imagen temporal definitiva ofrecida por el sintagma verbal.

Así, el punto de partida de su investigación es la hipótesis de considerar el sistema verbal del español como una estructura compleja, cuyos componentes se articulan en diferentes niveles según un principio didáctico.

Los diferentes niveles de la constitución temporal del sintagma verbal, según este autor, se estructuran en tres categorías principales: 1) categorías lexemáticas y sintagmáticas; 2) categoría perifrástica, y 3) categoría oracional. La primera categoría, operativa ya en el nivel de las proposiciones nucleares, es semántica léxica y se refiere a las propiedades accionales de los lexemas de base y, sobre todo, de los sintagmas verbales. La segunda categoría, de semántica gramatical, se compone de aquellos elementos morfológicos que, en el nivel de las proposiciones nucleares, modifican el carácter accional del lexema de base (estar + ger., soler + inf.) o sitúan el punto de perspectiva temporal en el enfoque externo (haber + part., ir a + inf.), que contribuye a formar las proposiciones nucleares de aspectualidad. La tercera es el conjunto de aquellos mecanismos que permiten la puesta en oración de las proposiciones nucleares y de esta manera crear enunciados concretos:

1. "Pepe, escribir, una carta".

2. "Pepe, estar escribiendo una carta", "Pepe, haber escrito, una carta”.

3. "Pepe escribe una carta", "Pepe escribía una carta", "Pepe estuvo escribiendo una carta", "Pepe había escrito una carta", etcétera.

Los diferentes niveles de la constitución temporal del sintagma verbal se superponen en el momento de la puesta en oración de las 
proposiciones nucleares. Havu enumera los diferentes niveles de la constitución temporal del sintagma verbal del verbo escribir y especifica en cada categoría las subcategorías de las que se compone:

\section{1) Categorías lexemáticas y sintagmáticas}

a. El primer nivel de la constitución temporal consiste en la raíz verbal escrib-.

b. En el segundo nivel se encuentra el lexema de base derivado de la raíz verbal, escribir, y los lexemas derivados del lexema de base, por ejemplo: reescribir, describir, prescribir, proscribir, etcétera.

c. En el tercer nivel se constituye el sintagma verbal de base añadiendo los complementos pertinentes al lexema de base o a los lexemas derivados. También la naturaleza del sujeto puede ejercer una determinada influencia para la constitución temporal. En este nivel se sitúan las propiedades accionales del verbo.

2) Categorías de perifrasticidad aspectual

a. El cuarto nivel es la aspectualidad fasal, que engloba las numerosas perífrasis ingresivas y egresivas (empezar a+ inf., dejar de + inf., etcétera).

b. El quinto nivel es la aspectualidad progresiva (estar + ger., ir + ger. etcétera).

c. El sexto nivel consiste en la aspectualidad resultativa, prospectiva y habitual (haber + part., ir a + inf., soler + inf.).

3) Categoría oracional

a. En este séptimo nivel se aplica al sintagma de base temporalidad (pasado, presente, futuro) y el aspecto gramatical (visualización externa us. visualización interna), acompañados de las referencias temporales o discursivas (Ayer hablé con Paco en el mercado; María entró mientras yo hablaba con Paco; De niño iba al colegio andando, etcétera).

Cada nivel de constitución temporal, salvo el primero, presupone uno o más niveles anteriores.

En el modelo de Havu, una situación S puede expresarse como: 1) proposición nuclear; 2) proposición nuclear de aspectualidad, y 3) oración, que puede ser enunciada en una situación conversacional o dentro de un texto discursivo:

\section{Cuadro 1}

1. "Pedro, escribir, una carta".

2. "Pedro, estar escribiendo, una carta".

"Pedro, ir a escribir, una carta".

"Pedro, soler escribir, una carta" etcétera.

3. Pedro escribió una carta.

Pedro ha escrito una carta.

Pedro escribía una carta.

Una proposición nuclear es la representación lingüística de una situación con forma de proposición desprovista de los elementos gramaticales de relación y de los complementos circunstanciales. Las proposiciones nucleares corresponden, por consiguiente, a la primera categoría de la constitución temporal, a saber, la de los niveles lexemáticos y sintagmáticos.

Desde el punto de vista formal, una proposición nuclear de aspectualidad es una representación idéntica a la proposición nuclear, pero corresponde a la categoría de aspectualidad perifrástica, la segunda categoría de la 
constitución temporal. La necesidad de establecer la diferencia entre las proposiciones nucleares y las proposiciones nucleares de aspectualidad reside en el hecho de que en estas ya se percibe la existencia de los enfoques desde los que puede ser visualizada una acción concreta. Por ejemplo, una proposición nuclear de aspectualidad resultativa como "Pedro, haber escrito, una carta" visualiza la situación desde fuera de sus límites temporales, aun tratándose de una pura representación teórica del proceso, mientras que una proposición nuclear de aspectualidad progresiva como "Pedro, estar escribiendo, una carta" presenta el evento desde dentro. En otras palabras, los enfoques de visualización están presentes, si bien de manera embrionaria, ya en el nivel de perifrasticidad. Además, en la proposición "Pedro, haber escrito, una carta" el enfoque de visualización no está del todo disociado de la acción propiamente dicha, sino que se presenta conceptualmente unido a ella. Este fenómeno nos permite intuir que existe una fase posterior al término de una situación y una fase anterior al inicio de una situación, "Pedro, ir a escribir una carta", que guardan una relación conceptual estrecha con el proceso o el estado propiamente dichos.

Si bien las formas verbales compuestas expresan tiempo verbal, en este trabajo se reconoce que llevan una significación aspectual evidente, incluso sin aparecer conjugado el verbo auxiliar, por la presencia del participio que aporta el carácter perfectivo o perfecto, en dependencia del enunciado en el que aparezcan.

Las oraciones son proposiciones enunciadas en un contexto conversacional o en otro tipo de entrono discursivo por un sujeto emisor al referirse a este en una situación real o conjetural.

De manera acertada, en su análisis Havu enfatiza que el tiempo verbal y el aspecto verbal no pueden ser reducidos a las proposiciones nucleares y se manifiestan solo en la categoría oracional, que conduce, por consiguiente, a la "puesta en oración" de las proposiciones nucleares y de las proposiciones nucleares de aspectualidad. Este planteamiento confirma que no podemos apreciar correctamente la significación temporal expresada por la forma verbal si no se tienen en cuenta los otros medios que contribuyen a expresar la temporalidad lingüística en el enunciado. No obstante, Havu llega solo al nivel de la "puesta en oración", pero hay otros medios más allá de ella que inciden en la expresión de la temporalidad.

Con los siguientes ejemplos Havu ilustra las características principales de las representaciones lingüísticas correspondientes a las tres categorías de la constitución temporal:

1. "Paco renovó su habitación".

2. "Ayer estuve viendo viejas fotos de la familia”.

El ejemplo 1 puede ser reducido a la proposición nuclear <Paco, renovar, una habitación>, mientras que 2 es la actualización oracional de la proposición nuclear de aspectualidad $<\mathrm{yo}$, estar viendo, fotos de familia $>$.

Existen casos especiales en los cuales una única construcción morfológica (por ejemplo, haber + part.) desempeña funciones divergentes:

3. "Pedro ha salido esta mañana a las diez".

4. "Pedro ha salido. Ya no está en su despacho".

La oración 3 es una actualización nuclear de la proposición "Pedro, salir", mientras que la oración 1 del ejemplo 4 es la actualización de la proposición nuclear de aspectualidad "Pedro, haber salido". En el caso de haber + part. es particular, dado que se trata de una sola construcción morfológica que tiene (al menos) dos funciones. Para lograr una correcta 
interpretación de esta construcción, es preciso recurrir a otros elementos gramaticales o a fenómenos extralingüísticos para establecer su verdadera naturaleza en la categoría oracional. Tal argumentación en pertinente para el análisis del corpus que se efectúa en la presente investigación.

Explica Havu que cada predicado verbal es la representación de una situación $S$, que puede ser expresada mediante una forma nominal o una forma conjugada:

5. "El correr veinte kilómetros cada día no me parece razonable".

6. "Paco corre veinte kilómetros al día, lo que no me parece razonable".

Las situaciones, según Havu, se dividen en eventos y estados. Por ejemplo:

7. "Pepe escribe una carta en el despacho".

8. "Madrid está en España".

En 7 el predicado evoca un proceso observable en su devenir, en este caso encaminado hacia la producción de una entidad no existente todavía (una carta). En cambio, en 8 se trata de algo que permanece inalterado durante un intervalo determinado. Estos ejemplos corresponden, por tanto, a las dos categorías principales de las situaciones, los eventos y los estados.

Los eventos son procesos que originan un cambio de un estado de cosas y que se desarrollan en el tiempo o se producen en un solo instante; por ejemplo, "María, escribir, una carta", "Pepe, abrir, una ventana". Los eventos se dividen en varias subcategorías definidas por sus propiedades accionales o agentivas. Define Havu como acciones los eventos originados o controlados por un agente, "Pepe, correr", o pseudoagente, "la lluvia, golpear, cristales", y procesos autónomos, como "llover"; los eventos que se encuentran fuera de cualquier entorno causal o agentivo. Las actualizaciones de estas proposiciones nucleares van a menudo acompañadas de complementos circunstanciales que contribuyen a localizar los eventos, a cuantificarlos, a determinar su duración o representar la manera como se desarrollan:

9. "Antes Pepe corría tres kilómetros cada domingo".

10. "Esta mañana, cuando me he despertado, la lluvia golpeaba insistentemente los cristales de mi habitación".

11. "El lunes pasado llovió desde las dos hasta las cuatro".

Los estados, en cambio, asignan a un sujeto una propiedad persistente o describen una situación estática o no localizable en un tiempo específico:

12. "Paco tiene los ojos azules".

13. "En España hay grandes ríos".

Los estados también se dividen en (al menos) dos importantes clases, según si el estado es considerado permanente o transitorio. Se puede deducir de estas denominaciones que los estados permanentes denotan la propiedad o estado inherente al sujeto, mientras que los estados transitorios describen un estado susceptible de ser modificado:

14. "Los niños están en el jardín".

Para Havu, la diferencia que existe entre estados y eventos, así como la subdivisión de estos en varias subcategorías accionales, es un fenómeno accional. Demuestra que esta distinción se realiza en el nivel de las proposiciones nucleares y no pertenece a la categoría oracional. 
La distinción entre evento y estado no es tan inequívoca como puede parecer. Existen varios predicados que en el nivel de las proposiciones nucleares evocan una imagen estativa, pero que debido a factores contextuales pueden recibir una interpretación no-estativa.

La importancia que Havu da a la distinción entre estados y eventos se basa en la composicionalidad de las propiedades accionales y agentivas. Se nota también la distinta compatibilidad de los estados y los eventos con otros elementos de la constitución temporal o de la categoría oracional.

Acerca de situaciones presentes, pasadas y futuras, dice que una situación S localizable en el pasado u observable o identificable en el presente posee características no compartidas con las situaciones asignadas a un instante o intervalo futuro visualizadas desde un enfoque subjetivo como posibles, deseables, necesarias, etc. A partir del momento del habla, que en un contexto de comunicación oral coincide con el punto de perspectiva temporal, se abren infinitas posibilidades de sucesión futura de situaciones; es decir, infinitos mundos posibles, mientras que (al menos en teoría) existe un solo pasado. Para reforzar su concepción Havu cita a Klein (1994), para quien todo lo que se sitúa antes del momento presente, "el tiempo de la experiencia del presente", es accesible únicamente a través de la memoria, y todo lo que se localiza después de él es solo anticipación.

Al hablar de situaciones futuras, la presencia de distintos mundos posibles es sistemática, por lo que la situación futura no tiene existencia real fuera de la mente del hablante. El carácter conjetural es sistemático al tratarse de situaciones venideras, mientras que en el caso de situaciones localizadas en el presente o en el pasado, se trata de áreas temporales donde la existencia de varios mundos posibles se debe a la ignorancia o incertidumbre del hablante.
El pasado y el futuro (el presente difiere grandemente de ambos) no presentan mayores divergencias en cuanto al uso de los distintos mecanismos aspectuales y temporales. Una situación es localizable en el futuro y en el pasado. En el pasado los verbos pueden también ir acompañados de complementos adverbiales de duración o de temporalidad interna:

15. "Leí este libro en dos horas, lentamente".

16. "Leeré este libro en dos horas, lentamente".

Tanto el pasado como el futuro pueden construir secuencias narrativas.

A pesar de las similitudes, hay diferencias considerables. En primer lugar, en el futuro solo en contados casos es posible establecer la diferencia aspectual similar a la que encontramos en el pasado; en segundo lugar, el comportamiento de haber + participio es diferente en el futuro del que tiene en el pasado y, en tercer lugar, el carácter "conjetural" del futuro se manifiesta también en lo morfológico.

Las diferencias cualitativas que existen entre una situación presente, por una parte, y las situaciones pasadas y futuras, por la otra, son importantes.

Las situaciones presentes son las únicas que se autolocalizan sistemáticamente; como localizador temporal funciona el momento del habla, el que desempeña también el papel de punto de perspectiva temporal. De ahí que una situación presente sea concebida como inacabada. Ese carácter inacabado (sea un evento en curso o un estado continuo, genérico o habitual) es un rasgo inherente a cualquier situación presente. Incluso, que el momento del habla coincida sistemáticamente con el punto de perspectiva temporal de una situación presente hace que cualquier expresión de calendario sea inútil para localizar el punto de perspectiva temporal. Tan solo son aceptadas aquellas indicaciones de localización temporal que delimitan el periodo dentro del que 
se inscribe una situación presente (hoy, esta semana, en estos tiempos, etc.). La imposibilidad de usar una expresión de calendario se pone de manifiesto también a través de la no sinonimia de hoy y, por ejemplo, este martes. Si bien este martes algunas veces puede indicar el día en el que está el momento del habla (sobre todo si se acentúa el pronombre: ESTE martes trabajo en casa, para indicar una oposición excepcional entre este martes y otros martes.), nunca puede considerarse como sinónimo de hoy, ya que está claro que puede indicar el martes más próximo en el pasado o en el futuro. Al utilizarse junto con una situación habitual, las expresiones del calendario localizan la ocurrencia de una acción habitual (Los martes estoy en casa). La incompatibilidad que se da entre una situación presente y una localización temporal del calendario explica que el presente, acompañado por un complemento adverbial de localización temporal, generalmente sea interpretado como la expresión de una situación no presente.

También son compatibles con presente los complementos adverbiales del tipo ahora, en este momento, pero el uso de estos complementos adverbiales no cambia la localización de la situación. Los complementos adverbiales ahora y en este momento favorecen una lectura persistente a costa de iterativa o genérica, pero de ninguna manera cambian la localización temporal de la situación. En otras palabras, parece totalmente innecesario asignar un localizador temporal o un punto de referencia a las situaciones que se desarrollan o existen en el momento presente.

Havu define una situación real como localizable en el tiempo, de acuerdo con criterios objetivos. Se trata de una actividad dinámica o de un estado de cosas que se produce o se produjo en un instante t que se extiende o se extendió en un intervalo i. Según este punto de vista las situaciones futuras nunca pueden ser reales. Las situaciones presentes, tanto si expresan una situación habitual o genérica, como si expresan una acción en curso o un estado que perdura en el momento del habla, están a caballo entre lo real y lo conjetural, ya que la realización definitiva de un evento presente o término de un estado presente o de una situación habitual pertenece al área de lo no real. Un caso análogo al presente es el copretérito persistente; esta forma denota una situación que está en curso o en existencia en un punto de perspectiva temporal, pero cuyo término puede ser determinado solo a través del contexto narrativo o del entorno conversacional.

Una situación conjetural se visualiza en el punto de perspectiva temporal como localizada fuera del tiempo real, deducida por un estado de cosas o necesaria o posible de acuerdo con creencias, sospechas, dudas, deseos, etc., del hablante. De esta definición se desprende que muy a menudo lo conjetural coincide con lo modal, pero son dos nociones diferentes, si bien intimamente relacionadas.

En el modelo que propone Havu para su estudio, los tiempos verbales son aquellas formas verbales que se manifiestan exclusivamente en la categoría oracional, y considera las formas de los tiempos compuestos hube hablado, habré hablado, habría hablado, así como he hablado y habría hablado en la acepción perifrástica, como actualizaciones de la perífrasis aspectual haber+ part. y que no son, por consiguiente, considerados tiempos verbales independientes. En cambio, los usos aorísticos de las construcciones he hablado y había hablado se denominan perfecto compuesto, PC y pluscuamperfecto, PPC, respectivamente. En esta interpretación del fenómeno resulta interesante la metodología para el análisis de la temporalidad expresada a través del sintagma verbal.

En la categoría de tiempos compuestos, Havu incluye también las formas acabo de hablar y acababa de hablar que denomina pasado reciente actual (PRA), y pasado reciente inactual (PRI). Explica, además, que su inclusión en la categoría tiempo verbal se debe a que 
estas construcciones no pueden reducirse a construcciones de aspectualidad perifrástica (donde se encuentra obviamente su origen diacrónico), ya que, por ejemplo, en una proposición nuclear de aspectualidad "Pedro, acabar de escribir, la carta" se interpretaría como una perífrasis fasal de terminatividad, lo que sucede también con la misma construcción con el auxiliar en infinitivo en una oración concreta:

1. "A Pedro le gustaría acabar de escribir la carta".

Lo dicho a propósito de PRA y PRI (que juntos forman la categoría temporal de pasado reciente $[\mathrm{PR}])$ vale también para los futuros voy a hablar e iba a hablar. Tanto la proposición nuclear "Pedro, ir a escribir, la carta" como el infinitivo oracional de estas construcciones se interpretarían sistemáticamente a manera de ocurrencia del verbo ir como verbo de movimiento:

\section{2. "Pedro quiere ir a escribir la carta".}

Por estas razones, las formas voy a hablar e iba a hablar en una de sus acepciones, a saber, la que sitúa una acción venidera en un instante o intervalos localizados en un futuro desvinculado del momento del habla, se denominan futuro actual (FA) y futuro inactual (FI).

A continuación, se presentan los que, según Havu, son los tiempos verbales del español. Aunque la propuesta es interesante, no es compartida en el presente trabajo, ya que en realidad acabar + infinitivo e ir + infinitivo se emplean esencialmente para modalizar la acción o expresar aspectualidad, como otras perífrasis no incluidas en el cuadro. La Nueva gramática de la lengua española, para referirse a estos casos, habla de perífrasis modales y tempoaspectuales. Las primeras expresan informaciones de diverso tipo relacionadas con la modalidad, fundamentalmente capacidad, posibilidad, probabilidad, necesidad y obligación. Las informaciones aportadas por las segundas afectan, en cambio, de forma más directa al tiempo y al aspecto. Aquí cabe distinguir aquellas en las que predominan los rasgos temporales, como ir a + infinitivo (Voy a decirte una cosa) o acabar de + infinitivo cuando expresa anterioridad reciente (El patrón acaba de salir), pero también las que denotan hábito, como soler + infinitivo, o repetición como volver $a+$ infinitivo (Hace poco volví a leer el Quijote).

\section{PROPUESTA DE HAVU}

Tiempos simples (véase tabla 10)

Tabla 10

Tiempos simples

\begin{tabular}{|l|l|l|}
\hline Presente & PRES & Hablo \\
Pretérito & PRET & Hablé \\
Imperfecto & IMP & Hablaba \\
Futuro & FUT & Hablaré \\
Condicional & COND & Hablaría \\
\hline
\end{tabular}

Nota. Tomado de Havu (1998).

Tiempos compuestos (véase tabla 11)

Tabla 11

Tiempos compuestos

\begin{tabular}{|l|l|l|}
\hline Perfecto compuesto & FIPC & He hablado \\
Pluscuamperfecto & PCP & Había hablado \\
Pasado reciente actual & PARA & Acabo de hablar \\
Pasado reciente inactual & PRI & Acababa de hablar \\
Futuro actual & FA & Voy a hablar \\
Futuro inactual & FI & Iba a hablar \\
\hline
\end{tabular}

Nota. Tomado de Havu [1998).

En su tesis, Havu indica que el análisis temporal significa fundamentalmente el estudio de la localización y ordenamiento de las situaciones, mientras que el aspecto es una categoría que se refiere a la visualización de una situación desde un enfoque interno o externo a esta. Sin embargo, añade que estas categorías están íntimamente relacionadas y que una separación tajante produce análisis incompletos. En la presente investigación se comparte tal criterio, pero se precisa que son categorías gramaticales diferentes, que nuclean campos semántico-funcionales 
distintos, aunque estrechamente relacionados, y que si bien el hablante integra ambos al seleccionar las formas verbales y los demás recursos para expresar las ideas, en este estudio solo se tendrán en cuenta los adjuntos que expresan valor aspectual, que a la vez permitan determinar la localización del evento en la línea temporal, por ejemplo en: "Ha trabajado en la universidad durante muchos años", el adjunto de duración durante muchos años indica duración, pero permite localizar el inicio del evento bastante alejado del momento cuando se produce la enunciación.

No solo las situaciones son objeto de análisis temporal, también los instantes e intervalos que pueden ser identificados por medio de complementos adverbiales o adjuntos de tiempo y elementos léxicos. En otras palabras, el mecanismo de visualizar una situación desde una perspectiva temporal es muy similar al mecanismo de visualizar un instante o un intervalo.

\section{PROPUESTA DE INSTRUMENTOS DE ANÁLISIS TEMPORAL QUE EMPLEA HAVU}

El origen temporal (От) es el centro deíctico de una situación discursiva, el momento desde el que se contempla la dimensión temporal. En una situación comunicativa normal, coincide con el momento del habla ( $\mathrm{MH})$, pero en el caso de textos literarios, chistes, cuentos, etc., es normal que no esté explícitamente localizado. El от еs una entidad parecida al origen de Rojo (1990); según este autor es "el punto cero con relación al cual se orientan de forma mediata o inmediata las situaciones", y al punto temporal cero de Lyons (1980) y Declerck (1991).

El punto de perspectiva temporal (PPT) es el instante o periodo de enfoque desde el que se visualiza la situación. Desde от se pueden localizar tanto las situaciones, como los instantes desde los que se visualizan:
1. "Carmen vino a casa ayer a las tres".

2. "Carmen dormía en casa ayer a las tres".

3. "Carmen dormía tranquilamente ayer entre las dos y las tres".

En 1 la expresión adverbial ayer a las tres se localiza a partir del MH, que le sirve de PPT. La expresión adverbial identifica el tiempo del evento Carmen vino. Cuando una situación y un evento se localizan a partir de un PPT, y cuando hay coincidencia completa entre el tiempo de la expresión adverbial y el tiempo de la situación, tenemos localización directa (denominada por Declerk [1991] localización no marcada). En 2, ayer a las tres no localiza la situación, que puede no haber terminado en el $\mathrm{MH}$, sino que localiza un instante, el PPT, desde el que se visualiza una situación simultánea con el instante referido. ${ }^{15}$ Es decir, ayer a las tres coincide con uno de los instantes de los que se compone el tiempo de ocurrencia de la situación "Carmen, dormir". En 3, el PPT de Carmen dormía está determinado por la expresión adverbial entre las dos y las tres, que coincide con un subintervalo de la situación que, según una interpretación intuitiva, ha empezado antes del punto inicial y terminado después del punto final del intervalo que constituye el PPT. En los siguientes ejemplos, tenemos otros casos en los que el PPT no coincide con el MH:

4. "Carmen vino a casa ayer a las tres. José se había ido dos horas antes".

5. "Carmen vino a casa ayer a las tres. José iba a irse dos horas después”.

El análisis temporal de la primera oración en los dos ejemplos es el mismo que en 1. En cambio, José se había ido y José iba a irse no se localizan directamente a partir del $\mathrm{MH}$, sino que se presentan como anterior y posterior,

15 Coincide con Bello y Rojo, que reconocen que el copretérito expresa simultaneidad. 
respectivamente, a Carmen vino. El evento Carmen vino, o mejor dicho, el tiempo de dicho evento, constituye el PPT desde el cual se visualiza José se había ido y José iba a irse. De manera análoga, las expresiones adverbiales dos horas antes y dos horas después se relacionan, no directamente con el $\mathrm{MH}$, sino con el tiempo a las tres del primer evento de Carmen vino. En el ejemplo 1 (que es idéntico a la primera oración de 4 y 5) hay en realidad un complemento adverbial de tiempo compuesto; ayer es un adverbio deíctico absoluto, ya que se relaciona directamente con el от, mientras que a las tres es un complemento deíctico relativo, cuya localización exacta se realiza a través de la existencia de un PPT que se relaciona de forma directa con от (ayer en 1), o bien con la ayuda de los tiempos verbales, en cuyo caso la expresión a las tres se localiza en el mismo día cuando se sitúa también el MH ("Carmen ha llegado a las tres", "Carmen llegará a las tres”), a no ser que la situación conversacional dé lugar a otra interpretación. Además, mientras que a las tres identifica el tiempo exacto del evento Carmen vino, así como el instante exacto desde el que se visualiza Carmen dormía de 3 , ayer establece un intervalo que sirve de cuadro temporal para el evento Carmen vino y para los eventos José se había ido y José iba a irse, que están, además, localizados con precisión por medio de los complementos deícticos relativos.

No es indispensable que el PPT esté localizado explícitamente en el tiempo. La situación conversacional y el fondo conversacional común de los interlocutores puede proporcionar suficiente información para que una localización explícita o precisa se conciba como innecesaria:
6. "Cuando nació mi hijo, vivíamos en Sala- manca".

El PPT de la situación vivíamos en Salamanca es el tiempo no especificado del primer evento nació mi hijo.
En 6 el PPT establecido por el tiempo del evento nació mi hijo coincide con uno de los instantes de los que se compone la duración total de vivíamos en Salamanca, y se da también la relación inversa, como hemos visto en 2 y 3.

\section{7. "Mi hijo nació en 1982".}

El tiempo del evento se localiza dentro del intervalo expresado por el complemento adverbial temporal en 1982 y el punto de perspectiva, temporal tanto del predicado como de la expresión adverbial de tiempo en el $\mathrm{MH}$.

En varios casos, el PPT, por ejemplo, en el análisis de PPC, se asemeja al punto de referencia, $\mathrm{R}$, de Reichenbach.

En el sistema de Havu cada instante o intervalo puede constituir un PPT desde el que se puede evaluar otro instante, intervalo o situación como anterior, simultáneo o posterior:

8. "Volví a casa ayer a las ocho, pero Juan se había ido a las siete".

9. "Me enteré ayer de que Juan había conocido a su mujer cuando él trabajaba en Madrid".

Los eventos volví a casa y me enteré, encontrados mediante localizadores temporales explícitos, se evalúan directamente desde el momento del habla (la inmediatez de esta relación es explicitada por medio del complemento adverbial deíctico ayer) que sirve, por consiguiente, de PPT. LOS PPT de los eventos "había salido" y "había conocido" son los eventos volvía a casa y me enteré, respectivamente. En lo que se refiere al tercer evento trabajaba, el PPT es establecido por el tiempo del segundo evento, "había conocido". Una situación es simultánea con el PPT solo si es durativa; el PPT tiene que coincidir con uno de los instantes o con un subintervalo, durante el cual tiene lugar la situación (ciertos verbos momentáneos requieren un análisis distinto). 
Desde el PPT una situación puede ser visualizada como presente, pasada o futura. Havu demuestra la estrecha interrelación que existe entre la significación temporal expresada por cada forma verbal y el resto del enunciado que viene a completar o precisar la expresión de temporalidad que porta este.

El modelo aplicado por Havu para el análisis de la constitución temporal del sintagma verbal —que se presenta a continuaciónpermite distinguir diferentes momentos en su constitución y delimita, acertadamente, la significación temporal de la significación aspectual, sin dejar de reconocer los indiscutibles nexos e interdependencia entre ambos.

\section{Categorías lexemáticas y sintagmáticas}

a. El primer nivel de la constitución temporal consiste en la raíz verbal escrib-.

b. En el segundo nivel se encuentra el lexema de base derivado de la raíz verbal, escribir, y los lexemas derivados del lexema de base reescribir, describir, prescribir, proscribir, etc.

c. En el tercer nivel se constituye el sintagma verbal de base y se incorporan los argumentos pertinentes al lexema de base o a los lexemas derivados; en el caso de escribir tiene la forma de "x, escribir" o "x, escribir, $\mathrm{y}$ ", donde $\mathrm{x}=$ sujeto agente de persona (por ejemplo, Pepe, mi hermano, yo, etc.) e $\mathrm{y}=$ complemento objeto de cosa (por ejemplo, la carta, las cartas, cartas, dos cartas, las dos cartas, etc.), definido o indefinido, contable o no. En el tercer nivel se sitúan las propiedades accionales del verbo.

2. Categorías de aspectualidad perifrástica a. El cuarto nivel es el de la aspectualidad fasal, que engloba las numerosas perífrasis ingresivas y egresivas:

empezar $a+\inf$.

estar a punto de + inf.

estar para + inf.

dejar de + inf.

terminar + inf. etc.

Las ingresivas, llamadas también incoativas, focalizan el inicio de la situación; las egresivas, que también son llamadas terminativas, según la Nueva gramática de la lengua española.

b. En el quinto nivel se constituyen las construcciones de aspectualidad progresiva,

estar + ger. y las variantes de la esta perífrasis:

ir + ger.

venir +ger

andar + ger.

seguir + ger.

c. El sexto nivel consiste en la aspectualidad resultativa, prospectiva y habitual:

haber escrito

ir a escribir

soler escribir

Puede entenderse la aspectualidad resultativa como aquella que pone de manifiesto el estado final del evento; la prospectiva, orientada a la posteridad, y la habitual, la que denota hábito. 


\section{Categoría oracional}

a. En el séptimo nivel se aplica al sintagma de base la temporalidad y el aspecto gramaticales acompañados de referencias temporales o discursivas.

En el séptimo nivel podemos identificar tres subcategorías, de las cuales dos, (1) y (2), son exclusivamente semánticas, mientras que en la otra (3) las funciones de los tiempos y de las categorías aspectuales se ven condicionadas por factores sintácticos:

- Tiempos fundamentalmente internos.

- Tiempos fundamentalmente externos.

- Oraciones subordinadas.

- "Ahora escribo/estoy escribiendo cartas".

-"Ayer a las dos escribía/estaba escribiendo una carta".

- "Ayer por la mañana escribí una carta a mi padre".

-"Esta mañana a las 8 he visto a Pedro en la calle".

-"Mañana escribiré la carta de invitación".

- $\quad$ "Cuando Pepe escriba la carta, se pondrá nervioso".

- "Cuando Pepe estuvo escribiendo la carta, se puso nervioso".

-"Cuando volviste de casa, estaba escribiendo la carta que ya sabes", etcétera.

Cada nivel de la constitución temporal, salvo el primero, presupone uno o más niveles anteriores.

Havu presenta dos niveles en la base de la constitución temporal del sintagma verbal por razones puramente teóricas. La existencia del primer nivel es superflua desde el punto de vista de la interpretación solo temporal o aspectual.

El sistema derivativo del español carece de marcadores aspectuales o temporales y, desde el punto de vista de la constitución temporal, los verbos derivados de la raíz verbal o del lexema de base habrán de colocarse en el mismo nivel como entidades independientes.

En el sistema pronominal se observa un comportamiento diferente. Según demuestra muy bien Havu, a menudo se podría considerar un verbo pronominal simplemente como un verbo derivado de la raíz verbal o del lexema de base. En este caso, el pronombre, en su calidad de marca semántica de incoación, es comparable con los afijos derivacionales que sirven para formar nuevos lexemas; por ejemplo, de dormir us. dormirse, que no tienen las mismas propiedades accionales. En cambio, la diferencia entre, lavar us. lavarse es de orden esencialmente actancial y no afecta el carácter accional del verbo. Un grupo aparte forman los verbos llamados verbos esencialmente reflexivos, también conocidos como cuasirreflejos o reflexivos de forma, del tipo de atreverse, arrepentirse, abstenerse, etc., que se situarán en el segundo nivel a la manera de dormirse. Este problema es de orden sintáctico e interesa solo en la medida en que tiene consecuencias temporales. Aunque en determinados casos, como el de dormir vs. dormirse, la pronominalización trae consigo un cambio aspectual y temporal importante, no es posible considerarla como un mecanismo aspectual y temporal sistemático, dado que en la mayoría de los casos no influye en las cualidades accionales de los verbos. Desde el punto de vista de la constitución temporal del sintagma verbal, es evidente que hemos de situar dormirse, aun tratándose de un verbo derivado de dormir, en el mismo nivel que el lexema de base, mientras que lavarse tiene que ubicarse en el nivel actancial de la 
constitución temporal. En el caso de dormirse, se hace sitúa la atención en el inicio de la acción, lo que corresponde al área de la aspectualidad, mientras que en lavarse, se refiere al argumento correspondiente, es decir, al complemento directo.

Otro problema es determinar la posición de la forma no personal (FNP) del verbo en la jerarquía de la constitución temporal. Todas estas formas evocan una imagen de orden temporal: el infinitivo se considera forma básica en español; es la forma inactualizada, el núcleo verbal que encierra en sí múltiples posibilidades combinatorias de la constitución temporal definitiva de las oraciones concretas.

En el tercer nivel el lexema verbal se combina con sus complementos para formar un sintagma verbal.

Aunque algunos sintagmas se forman ya en el segundo nivel (por ejemplo, llover, nevar, etc.), la gran mayoría de los sintagmas verbales se constituyen en el tercero, de manera que el segundo y el tercer nivel forman un todo coherente, el sintagma verbal de base, al que se aplican, en los dos niveles sucesivos, factores aspectuales y temporales externos. La presencia y la naturaleza de los complementos afectan de manera decisiva las propiedades accionales del verbo, los complementos influyen de modo decisivo en el carácter temporal de cualquier verbo.

El estudio de las propiedades accionales del verbo ha recibido diferentes denominaciones, según el aparato teórico. Las propiedades accionales del verbo son el elemento aspectual fundamental en el sistema verbal, puesto que están presentes ya en las proposiciones nucleares y condicionan el uso de los demás factores aspectuales y temporales (aspectualidad perifrástica, tiempo y aspectos gramaticales, complementos adverbiales temporales, etcétera), que tienen que adaptarse a los límites semánticos impuestos por ellas. En estas apreciaciones, Havu hace referencia a los llamados en la Nueva gramática de la lengua española, aspecto léxico, aspecto morfológico y aspecto perifrástico o sintáctico.

Las propiedades accionales del verbo son una categoría eminentemente sintagmática, de modo que la naturaleza de los argumentos (sujeto, complemento directo, complemento de lugar con los verbos de movimiento, entre otros) puede hacer que un verbo sea parte constitutiva de sintagmas verbales de distintas características accionales. En esta parte, Havu mezcla dos referentes teóricos diferentes: la teoría actancial de Tesnière y la de los casos semánticos de Fillmore. Por otro lado, parece demasiado absoluta la afirmación de que las propiedades accionales sintagmáticas son una categoría eminentemente sintagmática, puesto que no tienen en cuenta la significación del verbo. Según Ana Curbeira (2003), "el significado léxico y el gramatical de manera diferente y a distintos niveles, abstraen diferentes propiedades de los objetos" (p. 388). Los significados léxico y gramatical son aspectos diversos del significado lingüístico en unidad diversa. Las características de los verbos, sean accionales o estativos, influyen en las funciones que estos pueden asumir.

\section{Rojo y Veiga: temporalidad y tiempos verbales en español}

En 1974, Guillermo Rojo, en la revista Verba (número 1), expuso su caracterización de la temporalidad lingüística y su análisis del funcionamiento del verbo español actual. Estas ideas han sido reiteradas en publicaciones posteriores del autor, como los capítulos "Relaciones entre temporalidad y aspecto en el verbo español" (1990) y "Las construcciones sintácticas fundamentales. Relaciones temporales, aspectuales y modales" (Rojo y Veiga, 1999), de la Gramática descriptiva de la lengua española, coordinada por Ignacio Bosque y Violeta Demonte (1999). 
Rojo considera que los significados de los tiempos verbales se pueden obtener con un sistema de base deíctica que permite orientar las situaciones respecto a determinado punto, o bien otros que se miden por su relación con el anterior. Explica, además, que la falta de una distinción clara entre el tiempo físico y el tiempo verbal ha estado implícita en el tratamiento tradicional de este último, porque a las nociones de pasado, presente y futuro en la versión humanizada del tiempo físico corresponden las subcategorías temporales de pasado, presente y futuro, y destaca que haberle asignado a los tiempos verbales denominaciones que corresponden al tiempo físico: pasado, presente y futuro, al estudiar la temporalidad, ha sido una dificultad; algo que ya había advertido Bello.

Este autor se propuso demostrar que la temporalidad es una categoría plenamente vigente en el sistema verbal español y que con ella se puede explicar a la perfección el funcionamiento del conjunto de formas que integran los paradigmas verbales.

En sus trabajos, se define que el tiempo físico es exterior al hombre y presenta en él un correlato: el tiempo psíquico, que es la vivencia que cada hombre tiene del transcurrir del tiempo (véase figura 25).

FIGURA 25. Tiempo fisico. Tomado de Rojo y Veiga (1999).

Se especifica que el tiempo cronológico es el tiempo tal y como lo pensamos, como lo recordamos, y que tiene dos versiones: la objetiva y la subjetiva (véase figura 26).

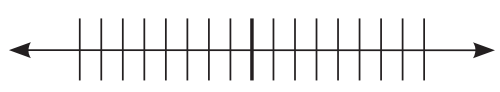

FIGURA 26. Tiempo cronológico. Tomado de Rojo y Veiga (1999).
La versión objetiva se ofrece en los calendarios y se caracteriza por:

1. Su condición estativa: hay un punto axial fijo, propio para cada cultura.

2. Su condición direccional: todo se sitúa antes o después de ese punto axial.

3. Su condición mensurativa: se lleva a cabo con unidades de medida segmentables (horas, minutos, años, días = 24 horas, etcétera).

El tiempo cronológico subjetivo es aquel en el que cada uno de los hombres determina cuáles son los acontecimientos que marcan su vida, con relación a los que es relevante establecer un antes y un después.

a. No había nacido yo cuando...

b. Acababa de terminar la carrera cuando...

El tiempo lingüístico se basa en el tiempo cronológico, pero no coincide totalmente con él; se fundamenta en el establecimiento de un punto cero, pero ese punto no es estático, sino móvil. Aunque no siempre ocurre de ese modo, en principio se puede considerar que el punto cero lingüístico coincide con el momento de la enunciación. Cada acto lingüístico se convierte, así, en su propio centro de referencia temporal, con respecto al cual los acontecimientos ${ }^{16}$ pueden ser anteriores, simultáneos o posteriores. La orientación directa o indirecta con respecto a este momento es la característica fundamental del tiempo lingüístico y la única que funciona en muchas lenguas. Todas las lenguas tienen la posibilidad de medir las distancias temporales mediante expresiones de tipo "veinte años antes, diez días después o dentro de quince minutos." Además, algunas han gramaticalizado esta posibilidad y

16 En el presente trabajo se asume el término evento, pero se respeta el utilizado por Rojo y Veiga. 
expresan sistemáticamente el grado de lejanía temporal. No es este el caso del español.

Las características fundamentales de la temporalidad lingüística son las siguientes:

a. Se basa en el establecimiento de un punto cero, que coincide habitualmente, pero no de manera forzosa, con el momento de la enunciación.

b. Frente a la linealidad y el carácter irreversible del tiempo físico, el lingüístico consiste en la situación de los acontecimientos en una zona anterior, simultánea o posterior con respecto al punto central. Lo fundamental es, por tanto, la "orientación" directa o indirecta de los acontecimientos respecto al punto cero.

c. En algunas lenguas está gramaticalizada la expresión de distancia del punto cero, no en el español.

El tiempo lingüístico puede ser representado, de manera provisional, como una línea con un punto central (O), doblemente orientada y abierta por ambos extremos, en la que los acontecimientos pueden ser situados en la zona de lo anterior (A), simultáneo (S) o posterior (P) al punto cero (véase figura 27).

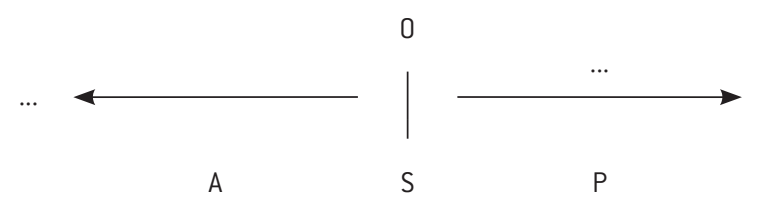

FIGURA 27. Tiempo lingüístico. Tomado de Rojo y Veiga (1999).

Rojo y Veiga (1990), al definir el tiempo verbal, apuntan la inadecuación de los planteamientos tradicionales de la temporalidad verbal para dar cuenta de los valores de las formas, los cuales en los últimos tiempos han dado lugar a la formulación de teorías que postulan la existencia de categorías complementarias. Considerando únicamente las que han sido más empleadas para el verbo español, las agrupan en los siguientes bloques:

a. La línea seguida primero por Benveniste (1959) y luego por Weinrich (1964). El factor común en ambos consiste en el establecimiento de dos grupos de formas verbales (historia y discurso en el primer caso, formas complementarias y formas narradoras en el segundo). Esta distribución es, en los dos autores, el gran principio organizador del sistema.

b. La línea que introduce en el verbo los llamados niveles o planos de actualidad, formulada ya por Damourette y Pichon (1936) para el verbo francés, reelaborada por Burger (1961 y 1962), adoptada posteriormente por Pottier (1969) para el español y aceptada luego por Lamíquiz (1969, 1971a, 1971b, 1972, 1982). Por una vía independiente a la de Pottier, pero con casi total coincidencia en los resultados que se obtienen en este punto concreto, Coseriu (1976), seguido por Cartagena (1978), considera los planos de actualidad como uno de los factores más característicos de los sistemas verbales románicos. La diferencia entre dos "perspectivas" (de presente o participación/de pasado o alejamiento) introducida por Alarcos Llorach (1959) en el estudio del verbo español presenta no pocas coincidencias con las mencionadas teorías.

Rojo y Veiga pretenden mostrar una teoría de las relaciones temporales que integre los fenómenos de interés que han sido puestos de relieve por otras aproximaciones. Así, fundamental como antecedente es la visión de las relaciones temporales expuesta por Andrés Bello en 1841 e incorporada luego a su Gramática.

Un punto cualquiera, orientado respecto al origen, puede convertirse en una referencia a la cual se sitúe un acontecimiento que está orientado directamente a esa referencia y solo indirectamente en cuanto al origen. 
El valor lingüístico de estas formas verbales se manifiesta realmente en su relación temporal con respecto a la referencia, pero no en su situación con respecto al origen. Había cantado expresa una situación anterior a una referencia anterior al origen y, puesto que la propiedad de anterioridad es transitiva, el que un evento $E_{1}$ sea anterior al punto de origen $\mathrm{O}$ y un evento $\mathrm{E}_{2}$ ( $\mathrm{E}=$ 'evento', cf. la terminología y simbolizaciones de Reichenbach (1947) sea a su vez anterior a $\mathrm{E}_{1}$ anterior al origen determina que también tenga que ser anterior a $\mathrm{O}$.

En cambio, cuando se trata de un acontecimiento $E_{2}$ posterior a una referencia $E_{1}$ anterior al origen, la situación de $E_{2}$ en cuanto al origen queda indeterminada. Ese es el caso del pospretérito:

a. Me prometieron que estarían aquí ayer.

b. Me prometieron que estarían aquí hoy.

c. Me prometieron que estarían aquí mañana.

En todos los ejemplos anteriores, prometieron tiene valor temporal anterior al origen y estarían expresa posterioridad a la referencia posterior al origen expresada en dicho verbo. Lo que sucede es que ese valor, que es lo que constituye su significado lingüístico, puede concretarse en una situación anterior, simultánea o posterior al origen. Eso es lo que marcan de forma explícita los adverbios de las secuencias, que se orientan de manera directa al origen y, como consecuencia de ello, muestran explícitamente las relaciones que lo expresado por cantaría mantienen con el punto central.

Si la expresión no contiene ninguna locución adverbial orientada directamente hacia el origen, la relación que la situación mantiene con el punto central queda indeterminada, como sucede en Me prometieron que estarían aquí al día siguiente que, en el contexto adecuado, puede corresponder a cualquiera de las posibilidades.
Para Rojo y Veiga el tiempo verbal es una categoría gramatical deíctica mediante la cual se expresa la orientación de una situación, ya sea con respecto al punto central (el origen) o a una referencia secundaria que, a su vez, está directa o indirectamente orientada con respecto al origen.

Que sea una categoría gramatical deíctica significa que establece un sistema centrado en una referencia interna que, en la interpretación más habitual, se identifica con el momento de la enunciación.

Las formas verbales orientan las situaciones expresadas con respecto al origen, al punto central de todas las relaciones. Explican Rojo y Veiga que localizan la situación, pero que debe entenderse que se trata de una localización en el sentido débil, el que se limita a presentar lo mencionado como anterior, simultáneo o posterior al origen, o a una referencia. No se trata, por tanto, de una localización en sentido estricto del establecimiento de un punto concreto en la línea del tiempo, a una distancia del origen determinada y bien establecida, sino de una orientación en cuanto al origen. La orientación que establece una forma de anterioridad como "llegué" puede luego complementarse con la localización más detallada que añaden expresiones adverbiales como "ayer, hace un mes, el 25 de enero de 1995”, etcétera.

Además de orientar directa o indirectamente con respecto al origen, algunas formas verbales tienen la característica de indicar una determinada localización (simultaneidad, por ejemplo) en relación con distintos puntos, sea el origen o cualquier otro:

a. Cuando llegamos a la estación, había dos hombres esperándonos.

b. Cuando lleguemos a la estación, habrá dos hombres esperándonos. 
Esperándonos marca en los dos ejemplos anteriores de simultaneidad, que se establece teniendo en cuenta un punto anterior al origen en (a) y a una referencia posterior al origen (b). Algo semejante ocurre en (1) y (2): llegar expresa simultaneidad y adoptado, anterioridad en diferentes momentos.

(1) a. Al llegar a la estación, encontré a dos hombres esperándome.

b. Al llegar a la estación, encontraré a dos hombres esperándome

(2) a. Una vez adoptado el acuerdo, suspendimos la reunión.

b. Una vez adoptado el acuerdo, suspendemos la reunión.

c. Una vez adoptado el acuerdo, suspenderemos la reunión.

(3) a. Nos \{dijo/dirá\}: <<ayer llovió>>.

b. Nos \{dijo/dirá\}: <<hoy llueve>>.

c. Nos \{dijo/dirá\}: <<mañana lloverá>>.

(4) a. Nos dijo que había llovido \{la víspera/el día anterior\}.

b. Nos dijo que llovía \{el/ aquel\} mismo día.

c. Nos dijo que llovería al día siguiente.

(5) a. Nos dirá que ha llovido \{la víspera/el día anterior\}

b. Nos dirá que llueve \{el/ ese\} mismo día.

c. Nos dirá que lloverá al día siguiente.

La diferencia entre las formas verbales y las expresiones adverbiales está en el hecho de que las primeras expresan relaciones que tienen que ver con referencias que poseen una orientación concreta con respecto al origen (en este caso, de anterioridad) y, por tanto, expresan anterioridad a una referencia anterior al origen (caso 4a), etcétera. De ahí que sean distintas las formas de las series (4) y
(5), ya que expresan relaciones con respecto a puntos con diferentes orientaciones en cuanto al origen. Las adverbiales, en cambio, expresan simplemente anterioridad, simultaneidad o posterioridad a cualquier punto, por lo que se mantiene constantes en las dos series.

Acerca de la identificación del punto de origen con el momento cuando se produce el acto verbal o la conceptualización -lingüísticade un proceso, Rojo y Veiga explican que no siempre resulta aceptable, por ejemplo, en la carta, en carteles de carretera, el presente histórico, etcétera.

En este caso, la localización del origen, centro deíctico de referencias del sistema temporal, puede ser variable. Su situación más habitual y espontánea lo hace coincidir con el momento de la comunicación verbal, pero determinados factores pueden alterar esta situación, localizándolo exclusivamente en función del emisor (y, por tanto, con anterioridad al establecimiento de una comunicación diferida) o haciéndolo coincidir con un punto diferente del 'ahora' de todos los interlocutores.

Rojo y Veiga no comparten plenamente la división entre términos absolutos y relativos. Distinguen entre formas con orientación alocéntrica y formas orientadas directa o indirectamente con respecto al origen. Como ya se ha indicado, el tiempo verbal es una categoría deíctica y, por tanto, todas las localizaciones son relativas.

Según los autores, la etiqueta empleada por Bello para cada forma refleja el valor temporal que posee (o, al menos, el que le atribuye). Él parte de tres valores básicos. "presente", "pretérito" y "futuro", y luego, mediante la adición de los prefijos ante-, co- y pos(t) -, crea una denominación que refleja casi exactamente los valores temporales, como figuran en las fórmulas que le hemos asignado; esto se ajusta al propósito de la presente investigación. 
La visión que tiene Bello de los valores de las formas verbales es fuertemente temporalista, por lo que las denominaciones que emplea reflejan solo el modo y el valor temporal. Otras visiones emplean parámetros diferentes en la clasificación de las formas y, naturalmente, utilizan las etiquetas que resultan adecuadas o necesarias desde esa perspectiva.

¿Cómo esquematiza Rojo la temporalidad expresada por las formas verbales del español? Establece que la relación temporal primaria es la expresada básicamente por cada forma, y se refleja en el vector primario, que es el que corresponde al extremo derecho de cada fórmula. El punto de referencia, que puede ser el origen o bien un punto situado con relación a él, es el que establece la situación en el eje temporal del momento en el cual las formas expresan la relación primaria. En las fórmulas, el punto de referencia es todo lo que queda a la izquierda del vector primario; se puede llamar también vector originario al situado inmediatamente después del símbolo del origen. ${ }^{17}$
Rojo representa las relaciones temporales como vectores así:

$$
\begin{gathered}
-\mathrm{V}(=\text { anterioridad }) \\
+\mathrm{V}(=\text { posterioridad }) \\
\mathrm{OV}(=\text { simultaneidad })
\end{gathered}
$$

De esta manera, en la fórmula $(\mathrm{O}-\mathrm{V}) \circ \mathrm{V}$, correspondiente a cantaba, se puede diferenciar entre el vector primario, que es de simultaneidad (oV), el punto de referencia, que es un punto anterior al origen $(\mathrm{O}-\mathrm{V})$ y el vector originario, que es de anterioridad (-V). Todo ello implica que el significado temporal básico de cantaba consiste en expresar una situación simultánea (relación temporal primaria) a un punto anterior al origen (punto de referencia).

En la tabla 12 se aprecia la distribución de las formas teniendo en cuenta la relación temporal primaria y el punto de referencia; asimismo, se puede ver que las formas aparecen únicamente en la casilla que contiene su realización temporal fundamental (véanse tabla 12 y figura 28).

\begin{tabular}{|c|c|c|c|c|}
\hline \multirow{2}{*}{\multicolumn{2}{|c|}{ Punto de referencia }} & \multicolumn{3}{|c|}{ Relación temporal primaria } \\
\hline & & $-\mathrm{V}$ & $\circ \mathrm{V}$ & $+\mathrm{V}$ \\
\hline 0 & & canté & canto & cantaré \\
\hline$(0-v)$ & & había cantado & cantaba & cantaría \\
\hline$(\mathrm{OoV})$ & & he cantado & & \\
\hline$(0+V)$ & habré cantado & & & \\
\hline$((0-V)+V)$ & habré cantado & & & \\
\hline
\end{tabular}

Distribución de las formas teniendo en cuenta la relación temporal primaria y el punto de referencia

Nota. Tomado de Rojo y Veiga (1999). 


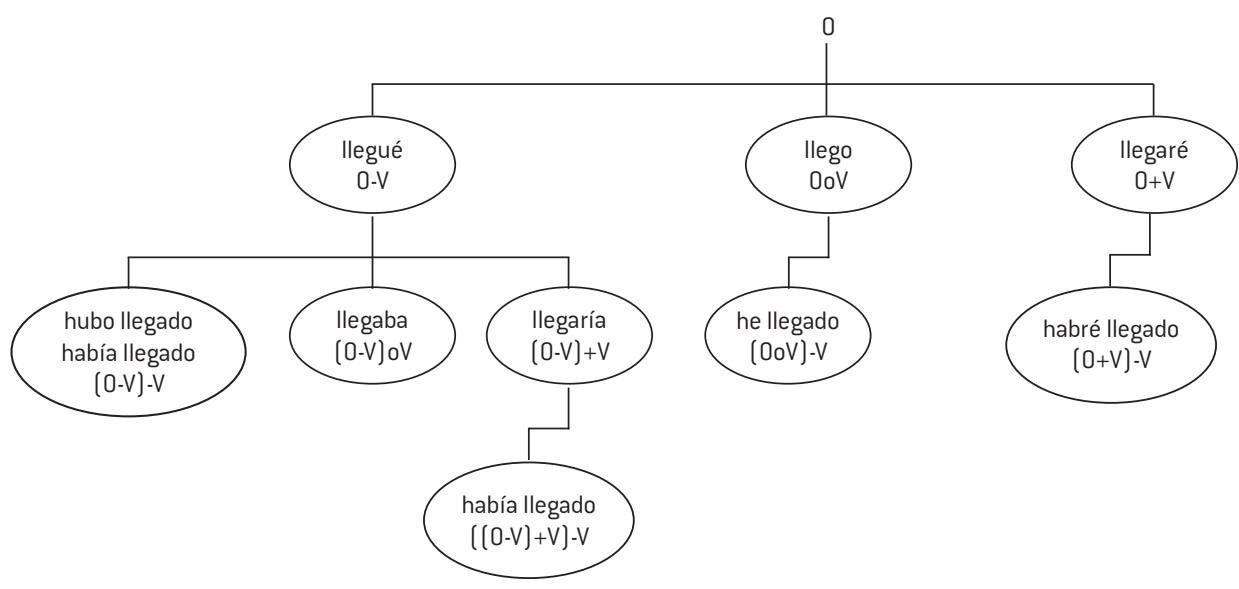

FIGURA 28. Esquema de la distribución de las formas teniendo en cuenta la relación temporal primaria y el punto de referencia. Tomado de Rojo y Veiga (1999).

Así, la situación de las columnas de la Tabla 12 muestra gráficamente los vínculos existentes entre las formas que poseen la misma relación temporal primaria. Así, canto y cantaba, tienen en común el hecho de ser formas que expresan primariamente simultaneidad, aunque canto lo hace con respecto al origen y cantaba con relación a un punto anterior al origen.

a. Dice que está ahora en la radio.

b. Dijo que estaba en aquel mismo momento en la radio.

Algo semejante ocurre con cantaré y cantaría, que son formas que expresan primariamente posterioridad y cuya diferencia consiste en que la primera lo hace hacia el origen y la segunda, a partir de un punto posterior al origen:

a. Dice que saldrá dentro de un rato.

b. Dijo que saldría un rato después.

Al tener en cuenta también el punto de referencia, la distribución reflejada en el cuadro permite explicar las conexiones que hay entre las formas que comparten este factor, como sucede con "canto" y "cantaré" o "cantaba” y "cantaría”. Por último, el cuadro muestra el carácter prioritario que la relación primaria de anterioridad posee en el sistema verbal del español contemporáneo. En realidad, tres de los cinco puntos de referencia que tenemos que distinguir no tiene formas propias más que para la expresión de la anterioridad con respecto a ellos (Rojo y Veiga, 1999, p. 2885).

$\begin{array}{lll}\mathrm{O}-\mathrm{V} & \text { pretérito } & \text { canté } \\ \mathrm{O} \mathrm{OV} & \text { presente } & \text { canto } \\ \mathrm{O}+\mathrm{V} & \text { futuro } & \text { cantaré } \\ (\mathrm{O}-\mathrm{V})-\mathrm{V} & \text { ante-pretérito } & \text { había cantado } \\ (\mathrm{O}-\mathrm{V}) \mathrm{OV} & \text { co-pretérito } & \text { cantaba } \\ (\mathrm{O}-\mathrm{V})+\mathrm{V} & \text { pos-pretérito } & \text { cantaría } \\ (\mathrm{O}-\mathrm{V})-\mathrm{V} & \text { ante-presente } & \text { he cantado } \\ (0+\mathrm{V})-\mathrm{V} & \text { ante-futuro } & \text { habré cantado } \\ ((0-\mathrm{V})+\mathrm{V})-\mathrm{V} & \text { ante-pos-pretérito } & \text { habría cantado }\end{array}$

En cuanto a las formas del modo subjuntivo, las relaciones temporales son un poco más difusas que en el indicativo, pero, según Rojo, pueden ser establecidas y las presenta esquemáticamente como se muestra en la tabla 13 y la figura 29).

Tabla 13

Modo subjuntivo

\begin{tabular}{|l|l|l|l|}
\hline & $-\mathrm{V}$ & oV & $+\mathrm{V}$ \\
\hline 0 & $\begin{array}{l}\text { llegara } \\
\text { llegase }\end{array}$ & llegue & Ilegue \\
\hline $0-\mathrm{V}$ & $\begin{array}{l}\text { hubiera llegado } \\
\text { hubiese llegado }\end{array}$ & $\begin{array}{l}\text { Ilegase } \\
\text { llegara }\end{array}$ & $\begin{array}{l}\text { Ilegase } \\
\text { Ilegara }\end{array}$ \\
\hline $\mathrm{O} \circ \mathrm{V}$ & haya llegado & & \\
\hline $\mathrm{O}+\mathrm{V}$ & haya llegado & & \\
\hline$(0-\mathrm{V})+\mathrm{V}$ & $\begin{array}{l}\text { hubiera llegado } \\
\text { hubiese llegado }\end{array}$ & & \\
\hline
\end{tabular}

Nota. Tomado de Rojo (1974). 


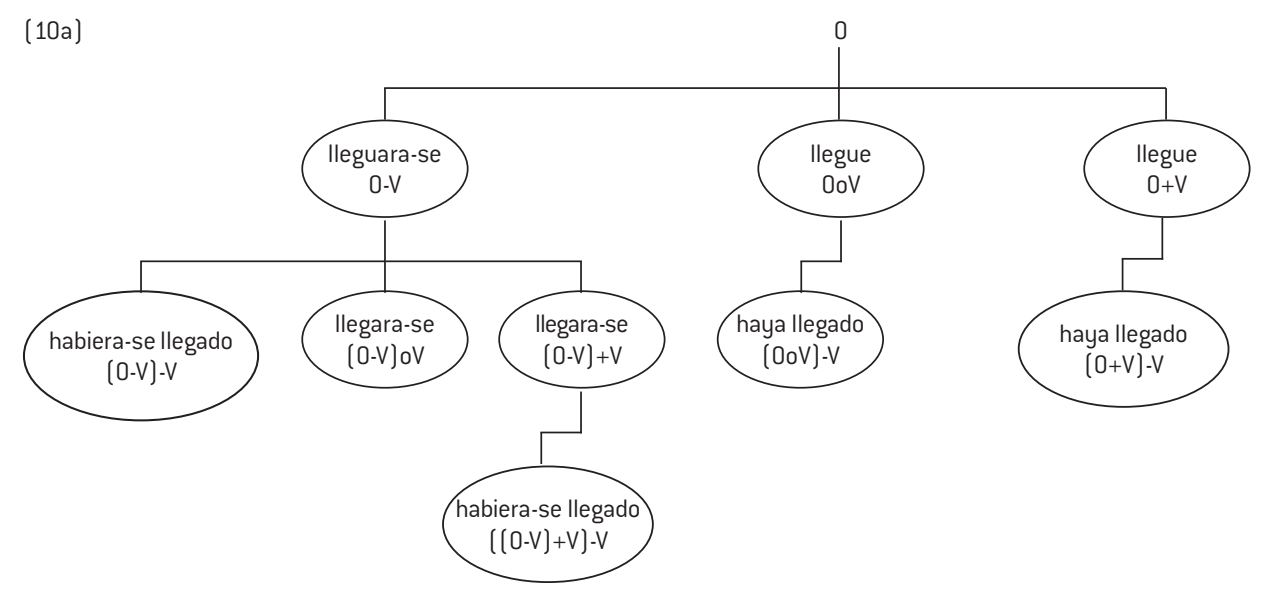

FIGURA 29. Esquema del modo subjuntivo. Tomado de Rojo (1974].

Rojo asigna a cada forma verbal una fórmula en la que se expresa su relación temporal primaria y, cuando existe, la secundaria. Pero, según él, no todos sus usos responden plenamente al valor asignado, hay extensiones o ampliaciones, neutralizaciones y la posibilidad de alterar la estructura del sistema en ciertos puntos y según unas líneas determinadas. A este fenómeno lo llama dislocación del sistema temporal. En los empleos dislocados, señalados como metafóricos por Bello, se suspenden ciertas características, pero conservan un paralelismo en varios puntos del sistema. Una forma verbal cualquiera, cuando es utilizada de acuerdo con el valor asignado, no añade por sí misma nada a la temporalidad pura y simple. Al lado de esto se constata la existencia de usos que no corresponden al valor inicial, es decir, que presentan una función temporal diferente de la que se refleja en esa fórmula, pero que, además, cargan la acción expresada de un cierto matiz que no pertenece a la esfera temporal. En otras palabras, existen formas que pasan de una función a otra, y ese traslado lleva consigo la adquisición de un cierto matiz extratemporal que no muestra cuando es utilizada acorde a su posición en el sistema. Como continúan expresando cierta relación temporal, aunque diferente a la atribuida en su primer examen, Rojo concluye que estos nuevos usos no niegan la temporalidad, sino que el desplazamiento en la función implica la expresión de matices no temporales añadidos.

Según Rojo, la dislocación es un hecho intrasistémico, perfectamente explicable como alteración de las relaciones temporales. Es todo un subconjunto de formas, definido a partir de un rasgo común, el que altera su posición en el sistema en un mismo sentido y consigue así la adición de un mismo significado no temporal.

Un primer caso de dislocación en el sistema temporal es el uso de una forma cuya función es indicar posterioridad, a un cierto punto, como el futuro, para expresar simultaneidad a él. Como resultado, el hecho adquiere un matiz complementario de probabilidad, que dentro de una estructura oracional adversativa se convierte en sentido concesivo.

El segundo caso se refiere a las formas que en su uso recto expresan anterioridad, como el copretérito, pero que cuando se emplean para indicar relación de simultaneidad llegan a adquirir matices que pueden agruparse bajo el término conjunto de "irrealidad".

Al abordar la cronología relativa, destacan que tanto las formas verbales como los adverbios y locuciones adverbiales de tiempo expresan una 
relación temporal de anterioridad, simultaneidad o posterioridad con respecto a un determinado punto. Las formas que indican esa relación con respecto a un punto cualquiera, sea el origen o cualquier otro, son alocéntricas. Las demás formas muestran relación temporal referida al origen, o bien a un punto de referencia que a su vez se orienta hacia el origen. Dado que el origen no es más que una especie de punto cero del sistema, todas las orientaciones expresadas por las formas verbales o adverbiales son, en el fondo, relativas, a criterio de Rojo y Veiga. Lo que resulta decisivo es la consideración de una forma verbal (o adverbial) es el valor temporal que expresa primariamente, esto es, lo que hemos llamado una relación temporal primaria.

Las formas no alocéntricas pueden estar orientadas con respecto al origen (canté, por ejemplo), a una referencia situada a su vez con relación al origen (como cantaría) o a una referencia, situada con respecto a una referencia que, al mismo tiempo, se encamina hacia el origen. Hay, pues, una clara dependencia de unos puntos de referencia respecto a otros, lo cual remite a una jerarquización.

El origen y los puntos de referencia secundarios o terciarios son, en realidad, entidades del mismo tipo. El origen, punto central del sistema con respecto al cual se orientan todos los demás, no es distinto de los demás puntos de referencia, sino solo el más importante de ellos $\mathrm{y}$, aunque coincide habitualmente con el momento del habla, puede admitir desplazamientos.

La cronología relativa que las formas verbales muestran entre sí o con respecto a expresiones temporales de diferente tipo da lugar a la correlación temporal o consecutio temporun. La correlación temporal es la consecuencia directa del hecho de que las formas verbales expresen relaciones temporales y que los puntos indicados por unas puedan convertirse en referencias a partir de las cuales se orienten otras, como se ve en los ejemplos siguientes:

(1) a. Nos \{dijo/dirá\}: "ayer llovió".

b. Nos \{dijo/dirá\}: "hoy llueve”.

c. Nos \{dijo/dirá\}: "mañana lloverá”.

(2) a. Nos dijo que había llovido \{la víspera/el día anterior\}.

b. Nos dijo que llovía \{el/ aquel\} mismo día.

c. Nos dijo que llovería al día siguiente.

El paso del estilo directo al indirecto y la consiguiente modificación de la estructura sintáctica permite que el verbo de la cláusula incrustada (llover) tome como punto de referencia el de la cláusula dominante (decir) y exprese, con respecto al punto $\mathrm{O}-\mathrm{V}$ señalado por este, una relación de anterioridad, simultaneidad o posterioridad. Se trata, por tanto, siempre del mismo principio.

Aunque las gramáticas se refieren a la correlación temporal casi de manera exclusiva en relación con las estructuras complejas en las que una oración depende sintácticamente (las llamadas subordinadas sustantivas, por ejemplo) y, además, enfocan el fenómeno con intención normativista, la correlación temporal, en realidad, remite a algo mucho más amplio, que abarca todo lo referente a la expresión lingüística de las relaciones temporales existentes en las situaciones). En efecto, las relaciones temporales entre los acontecimientos referidos son las mismas en los ejemplos de las series (a) y (b):

(3) a. Lo veo: ha salido de la Facultad.

b. Veo que ha salido de la Facultad.

(4) a. Entonces comprendí la razón de su marcha: había encontrado algo mejor.

b. Entonces comprendí que había encontrado algo mejor. 
(5) a. Habian cerrado la campaña el día anterior, descansaban aquel día y votarían al siguiente.

b. Supe por el periódico que habían cerrado la campaña el día anterior, descansaban aquel día y votarían al siguiente.

Comprender de forma correcta la cronología relativa y la correlación temporal exige tener en cuenta que las mismas relaciones temporales entre los acontecimientos pueden ser enfocadas de modos diversos y, en consecuencia, expresadas de distintas maneras. Por una parte, la orientación con respecto a la forma verbal de la cláusula u oración gramatical dominante no es la única posibilidad existente. Lo que se presenta habitualmente en las gramáticas como ruptura de la correlación temporal es el resultado de la prioridad concedida en ciertos casos a la orientación con respecto al origen, que no es contradictoria con la otra. A un verbo principal en pasado puede seguir una subordinada de cualquier forma.

\section{RESUMEN DE USOS RECTOS Y USOS DISLOCADOS, SEGÚN ROJO}

\section{Usos rectos}

Formas que indican primariamente posterioridad:
a. O+V llegaré llegue
b. $(\mathrm{O}-\mathrm{V})+\mathrm{V}$ llegaría llegara-se
c. $(\mathrm{O} \circ \mathrm{V})+\mathrm{V}$ llegaré llegue
d. $(\mathrm{O}+\mathrm{V})+\mathrm{V}$ llegaré llegue
e. $((\mathrm{O}-\mathrm{V})+\mathrm{V})+\mathrm{V}$ llegaríallegara-se

\section{LLEGARÉ 0+V}

(2)
a. $\mathrm{O}+\mathrm{V}$
llegaré

Seguro que vendrá mañana / la semana próxima / después / cuando amanezca. b. $(\mathrm{O} \circ \mathrm{V})+\mathrm{V}$ llegaré

Seguro que vendrá hoy mismo / esta semana/ ahora.
c. $(\mathrm{O}+\mathrm{V})+\mathrm{V}$ llegaré

Seguro que vendrá después de que cenemos / después del lunes.

\section{LLEGARÍA (O-V)+V}

a. $(\mathrm{O}-\mathrm{V})+\mathrm{V}$ llegaría

i) Me prometió que lo haría ayer/ mañana/hoy.

ii) Recordé que llamarías más tarde.

En el contexto adecuado, también sirve como:
a. $((\mathrm{O}-\mathrm{V})+\mathrm{V})+\mathrm{V}$

Dijo que volvería después del próximo verano.

b. $((\mathrm{O}-\mathrm{V})+\mathrm{V})-\mathrm{V}$

Dijo que volvería antes del próximo verano.

$$
\text { C. }((\mathrm{O}-\mathrm{V})+\mathrm{V}) \mathrm{OV}=(\mathrm{O}-\mathrm{V})+\mathrm{V}
$$

Dijo que volvería el próximo verano.

Formas que indican primariamente simultaneidad:
a. OoV llego llegue
b. (O-V)oV llegaba llegara-se
c. (OoV)oV llego llegue
d. $(\mathrm{O}+\mathrm{V})$ oV llegaré llegue
e. $((\mathrm{O}-\mathrm{V})+\mathrm{V})$ oV llegaría llegara-se

\section{LLEGO OoV}

presente puntual:

6) a. i) Abro la puerta. 
ii) Cierro el libro.
iii) Cortan flores.

presente actual:

b. i) Estudia tercero.

ii) Vivo en el campo.

iii) Escribo un libro.

presente permanente:

c. i) La tierra gira alrededor del sol.

ii) Tres y dos son cinco.

iii) Barcelona está en la costa.

presente habitual:

d. i) Desayuno a la inglesa.

ii) Aquí para el autobús.

iii) Los domingos me levanto tarde.

presente histórico:

e. i) En 1492 Colón descubre América.

ii) Ayer la encontré en la calle... Me acerco a ella y le digo...

\section{LLEGABA (O-V) OV}

puntual:

(7) a. i) Cuando lo vi abría la puerta.

ii) Cuando lo vi cerraba el libro.

iii) Cuando los vi cortaban flores.

actual:

b. i) El año pasado estudiaba tercero.

ii) El año pasado vivía en el campo.

iii) El año pasado escribía un libro.

permanente:

c. i) Copérnico probó que la tierra giraba alrededor del sol. ii) Estaba tan borracho que no recordaba que tres y dos eran cinco.

iii) Dijo que Barcelona estaba en la costa.

iv) La mujer que conocí se llamaba Olga.

habitual:

d. i) Cuando era joven desayunaba a la inglesa.

ii) Aquí, cuando yo era joven, paraba el autobús.

iii) Cuando era joven los domingos me levantaba tarde.

\section{LLEGO/LLEGABA}

Empleos "absolutos" de llegaba (se puede sustituir por llegó)

(8) a. Aquí estaba la estación de ferrocarril.

b. Mi abuela tenía una farmacia en Bilbao.

c. En esta calle vivían mis tías.

Simultaneidad us. posterioridad

presente pro-futuro:

(9) a. i) Mañana salgo (=saldré) de viaje. $[\mathrm{O}+\mathrm{V}]$

ii) Cuando la vea le digo (=diré) cuatro cosas. $[\mathrm{O}+\mathrm{V}]$

pro-futuro:

(10) a. i) Dijo que al día siguiente salía (=saldría) de viaje. [(O-V)+V]

ii) Pensó que cuando la viera le decía (=diría) cuatro cosas. $[(\mathrm{O}-\mathrm{V})+\mathrm{V}]$

iii) Cuando veas que el puchero hierve ("hervirá), quítalo del fuego.

iv) Si mañana hace (*hará) buen tiempo, saldré. 
(11) (OoV)-V he llegado /(O+V)-V habréllegado

a. Cuando veas que el puchero ha hervido lo sacas del fuego.

b. Si mañana no he recibido respuesta, consideraré que no te interesa el trabajo.

\section{LLEGUE}
a. ¡Ojalá venga mañana! $[\mathrm{O}+\mathrm{V}]$
b. ¡No puedo creer que estés aquí ahora! [OoV]

Formas que indican primariamente anterioridad:
a. O-V llegué llegara-se
b. (O-V)-V había llegado
hubiera-se llegado
hube llegado
c. (OoV)-V he llegado
haya llegado
d. $(\mathrm{O}+\mathrm{V})-\mathrm{V}$ habré llegado
haya llegado
e. $((\mathrm{O}-\mathrm{V})+\mathrm{V})-\mathrm{V}$ habría llegado hubiera-se llegado

\section{LLEGUÉ O-V}

(14) a. Me disgustó su actitud.

b. Esperé toda la tarde.

\section{HE LLEGADO (OoV)-V (p.104)}

(15) a. Este año he estado en Mallorca.

b. Me ha disgustado su actitud.

c. He esperado toda la tarde.

d. Cuando veas que el puchero ha hervido (*habrá hervido), quítalo del fuego.

e. Si mañana no he recibido (*habré recibido) noticias tuyas, saldré.

\section{LLEGUÉ O-V y HE LLEGADO (O०V)-V}

a. Llegó ayer.

b. El cometa Haley ha pasado tres veces este milenio.
a. Lo he visto anoche.
b. No he nacido ayer.

\section{HABÍA LLEGADO/HUBE LLEGADO (0-V]-V}
a. Cuando llegué, había salido.
b. Creí que ya se lo habían dicho.

a. El insigne escritor, que naciera (había nacido) en este lugar, volvió al escenario de su infancia.

Hube llegado se usa escasamente solo en oraciones temporales que indican sucesión inmediata.

(20) a. En cuanto hubo salido, corrí a la puerta.

b. Cuando hubo terminado, se acostó.

c. Luego de que hube comido, salí a dar un paseo.

\section{HABRÉ LLEGADO $(0+\mathrm{V})-\mathrm{V}$}

a. Cuandollegues, mehabrémarchado.

b. Lo habré terminado a final de mes.

c. Cuando vuelvan, habrán recapacitado.

\section{HABRÍA LLEGADO ([O-V)+V)-V}

a. Me dijo (A2) que, cuando volvieras (A3), se habría marchado (A1).

b. Aseguró (A2) que lo habría terminado (A1) a final de mes (A3). 


\section{LLEGARA/SE}
a. O-V llegué llegara-se
b. (O-V)oV llegaba llegara-se
c. $(\mathrm{O}-\mathrm{V})+\mathrm{V}$ llegaría llegara-se

(24) $\quad \mathrm{PoV}=\mathrm{P}$
a. $\mathrm{O}-\mathrm{V}$
Se lo dijeron.
Quizá se lo dijeran-sen.
b. (O-V)oV Creía que estabas en casa.
No creía que estuvieras-ses en casa.

\section{(25) PoV por $\mathrm{P}+\mathrm{V}$}
a. $(\mathrm{O}-\mathrm{V})+\mathrm{V}$
Dijo que se marcharía.
Le pedí que se marchara-se.
b. (O-V)oV Dijo que se marchaba enseguida.
Le pedí que se marchara-se enseguida.

\section{HAYA LLEGADO (O०V)-V}

a. No creo que hayan trabajado $[(\mathrm{O} \circ \mathrm{V})-\mathrm{V}]$ hoy, es fiesta.

b. Escríbeme cuando hayas desembarcado $[(\mathrm{O}+\mathrm{V})-\mathrm{V}]$.

\section{HUBIERA-SE LLEGADO (0-V)-V}

a. Me informaron que habíais llegado.

b. No me informaron que hubierais-seis llegado.

c. Me dijeron que las cosas habían cambiado mucho.

d. No esperaban que las cosas hubieran-sen cambiado tanto.
(28)

$(\mathrm{O}-\mathrm{V})+\mathrm{V})-\mathrm{V}$

a. Pensó que a las diez habrían acabado las entrevistas. Dijo que lo llamarían antes de esa hora.

b. Dijo que lo llamarían antes de que hubieran-sen acabado las entrevistas.

\section{Usos dislocados}

Usos dislocados de las formas de posterioridad:

$\mathrm{P}+\mathrm{V} \longrightarrow \mathrm{PoV}(+$ probabilidad)
a. llegaré
$\mathrm{O}+\mathrm{V}$
b. habré llegado
$(\mathrm{O}+\mathrm{V})-\mathrm{V}$
c. llegaría
$(\mathrm{O}-\mathrm{V})+\mathrm{V}$
d. habría llegado
$((\mathrm{O}-\mathrm{V})+\mathrm{V})-\mathrm{V}$

\section{USO RECTO}

a. Dentro de un rato serán las ocho.

b. Jonás tendrá dieciocho años en el año 2000.

c. Después del cine, estarán en el restaurante de al lado.

a. Cuando acabemos de cenar habrán dado las doce.

b. Jonás habrá cumplido dieciocho años en el año 2000.

c. Después del cine, habrán reservado mesa en el restaurante de al lado.

a. Pensé que dentro de un rato serían las ocho.

b. Pensé que Jonás tendría dieciocho años en el año 2000.

c. Dijeron que después del cine, estarían en el restaurante de al lado. 
(34) a. Pensé que cuando acabáramos de cenar habrían dado las doce.

b. Pensé que Jonás habría cumplido dieciocho años en el año 2000.

c. Dijeron que después del cine, habrían reservado mesa en el restaurante de al lado.

\section{USO DISLOCADO}

$\mathrm{O}+\mathrm{V}$ (llegaré) $\longrightarrow \mathrm{OoV}$ (llego) + probabilidad

a. Ahora serán (= son) las ocho.

b. Ahora Jonás tendrá (= tiene) dieciocho años.

c. A estas horas estarán (= están) en el restaurante de al lado, como todos los días.

(36) (O+V)-V (habré llegado) --> (OoV)-V (ha llegado) + probabilidad

a. Ahora habrán dado (= han dado) las doce.

b. Ahora Jonás habrá cumplido (= ha cumplido) dieciocho.

c. Ya habrán reservado (= han reservado) mesa en el restaurante de al lado.

(37) (O-V)+V (llegaría) --> (O-V) oV (llegaba) + probabilidad

a. Dijo que serían (= eran) las ocho.

b. Dijo que Jonás tendría (= tenía) dieciocho años, por esas fechas.

c. Dijo que a estas horas estarían (= estaban) en el restaurante de al lado, como todos los días.
(38)

((O-V)+V)-V (habría llegado) --> ((O-V) oV)-V (había llegado) + probabilidad

a. Dijo que ya habrían dado (=habían dado) las doce.

b. Dijo que Jonás ya habría cumplido (= había cumplido) dieciocho años por aquellas fechas.

c. Dijo que ya habrían reservado (= habían reservado) mesa en el restaurante de al lado.

\section{USO RECTO}

a. Será buena persona, cuando crezca.

b. Pensé que sería muy guapo cuando creciera.

c. Habrá roto muchos corazones antes de dos años.

d. Pensé que habría acabado la carrera en dos años.

\section{USO DISLOCADO: valores concesivos}

a. Será (= [aunque] probablemente es) buena persona, pero no lo parece.

b. Pensé que sería (= [aunque] probablemente era) muy guapo, pero era un perfecto idiota.

c. Habrá roto (= [aunque] probablemente ha roto) muchos corazones, pero no es muy atractivo.

d. Pensé que habría acabado (= [aunque] probablemente había acabado) la carrera, pero no se le notaba.

Usos dislocados de las formas de anterioridad:

$\mathrm{P}+\mathrm{V} \longrightarrow \mathrm{PoV}$ (+ irrealidad) 
(42)
a. llegué O-V
b. había llegado (O-V)-V
c. llegaba (O-V)oV
d. llegaría $(\mathrm{O}-\mathrm{V})+\mathrm{V}$
e. habría llegado $((\mathrm{O}-\mathrm{V})+\mathrm{V})-\mathrm{V}$
f. he llegado (OoV)-V
g. habré llegado $(\mathrm{O}+\mathrm{V})-\mathrm{V}$
h. llegara/se O-V
i. hubiera/se llegado (O-V)-V
j. haya llegado (OoV)-V

a. ?? Quería (= quiero + irrealidad) unos pantalones.

\section{LLEGABA/HABÍA LLEGADO por LLEGO/HE LLEGADO}

valor de irrealidad,

(O-V)oV (llegaba) --> (OoV)oV (llego) + irrealidad

a. [...] Tú hazte cuenta que vamos los dos en una barca. Oye, ¡qué divertido! Tú eras el que iba remando; la mar estaba muy revuelta, [...]

(45) (O-V)-V (había llegado) --> (OoV)-V (he llegado) + irrealidad

a. Tú hazte cuenta que vamos los dos en una barca. Oye, iqué divertido! Tú eras el que había remado todo el rato y estabas muy cansado.

valor prelúdico,

(46) (O-V)oV (llegaba) --> (OoV)oV (llego) + irrealidad

a. Yo era (= soy + irrealidad) el caballero y vosotros erais (= sois + irrealidad) los ogros.
(O-V)-V (había llegado) --> (OoV)-V (he llegado) + irrealidad

a. Yo había perdido (= he perdido + irrealidad) la espada pero tenía (= tengo + irrealidad) un puñal.

con este valor prelúdico no es posible la forma llegaría:

a. ?? Yo sería el policía y vosotros los ladrones.

\section{LLEGARA-SE/HUBIERA-SE LLEGADO por LLEGUE/HAYA LLEGADO,}

valor de irrealidad,

O-V (llegara-se) --> OoV (llegue) + irrealidad
a. ¡quién supiese alemán!
b. iquién pudiera volver!
c. *iquién sepa alemán!
d. ¡quién sabría alemán!

O-V (llegara) --> OoV (llegue) +
"irrealidad" a. ¡Ojalá llegasen-ran (= lleguen + irrealidad) a tiempo!

(O-V)-V (hubiera-se llegado) --> (OoV)-V (haya llegado) + irrealidad

a. ¡Ojalá hubiera-se llegado (= haya llegado + irrealidad) a tiempo! (pero he llegado tarde)

\section{LLEGARÍA/HABRÍA LLEGADO por LLEGARÉ/ HABRÉ LLEGADO}

$$
\begin{aligned}
& (\mathrm{O}-\mathrm{V})+\mathrm{V} \text { (llegaría) --> (OoV)+V (llegará) } \\
& \text { + irrealidad }
\end{aligned}
$$


a. Hablaría (= hablaré + irrealidad) contigo mañana, pero no estaré en Barcelona.

b. De buena gana iría (= iré + irrealidad) al partido (pero no puedo).

(53) $\quad((\mathrm{O}-\mathrm{V})+\mathrm{V})-\mathrm{V}$ (habría llegado) --> $((\mathrm{O} \circ \mathrm{V})+\mathrm{V})-\mathrm{V}$ (habré llegado) + irrealidad

a. Habría redactado los informes (= habré redactado + irrealidad) para mañana, pero no estaré en Barcelona.

b. De buena gana habría visto (= habré visto + irrealidad) el partido (pero no podré) antes de la comida familiar del domingo.

Otros valores modales con usos dislocados de formas verbales:

(54) a. Me gustaría hablar contigo.

b. Sería maravilloso que me llamaras.

valor de cortesía,

(O-V)oV (llegaba) --> (OoV)oV (llego) + cortesía

a. Quería (= quiero + cortesía) pedirle un favor.

b. ¿Podía (= puedo + cortesía) hablar con usted un momento?

c. Debías (= debes + cortesía) estudiar más.

(56) llegara --> ?? + cortesía

a. Quisiera (= quiero + cortesía) pedirle un favor.

b. Debieras (= debes + cortesía) estudiar más.

(57) llegaría --> ?? + cortesía a. ¿Podría (= puedo + cortesía) hablar con usted un momento?

b. Deberías (= debes + cortesía) estudiar más.

había llegado --> ?? + cortesía

a. * Había querido pedirle un favor (ayer).

(59) hubiera llegado --> ?? + cortesía

a. *Hubiera querido pedirle un favor (ayer).

(60) habría llegado --> ?? + cortesía

a. * ¿Habría podido hablar con usted un momento (ayer)?

(61) (Si es posible), quiero/querré esto (condicional real --> no cortés).

a. Quiero pedirle un favor.

b. ¿Puedo hablar con usted un momento?

c. Debes estudiar más.

(62) (Si fuera/fuese posible) quería/querría/quisiera esto (condicional irreal --> cortés).

a. Quería/querría/quisiera pedirle un favor.

b. Debías/deberías/debieras estudiar más.

c. Me gustaría hablar contigo.

d. Sería maravilloso (si me llamaras).

(Si es posible, que lo es),

a. Quiero pedirle un favor.

b. ¿Puedo hablar con usted un momento?

c. Debes estudiar más. 
(64) (Si fuera/fuese posible, que no lo parece)

a. Quería/querría/quisiera pedirle un favor.

b. Debías/deberías/debieras estudiar más.

c. Me gustaría hablar contigo.

d. Sería maravilloso que me llamaras.

Como puede apreciarse, la propuesta teórica anterior explica, de manera coherente, los valores de los tiempos verbales en español, tanto los que se corresponden con los usos rectos, como aquellos que llamó Bello metafóricos y Rojo, dislocados. Al mismo tiempo, Rojo y Veiga, tratan de abstraerse en el análisis de los valores aspectuales de las formas verbales, que consideran una categoría subordinada a la categoría de tiempo en español.

Rojo y Veiga citan a Coseriu (1999, p. 2919) cuando se refiere a las categorías gramaticales como clases universales de contenido gramatical y entiende por tales las posibilidades del lenguaje que pueden aparecer realizadas en las lenguas. Sin embargo, esto no implica que todas las categorías dignas de consideración en una perspectiva de lingüística general tengan que estar funcionalmente presentes en todas las lenguas o en todos los puntos de la gramática de una lengua dada. Una categoría existe en el sistema gramatical de una lengua si funciona en él como categoría autónoma, representada como tal por oposiciones específicas no reducibles a otras categorías. Si se restringe la aplicación de esta afirmación, que se desprende del principio de la funcionalidad, al terreno estricto del sistema verbal propiamente dicho se comprenderá que para postular la existencia del mismo aspecto como categoría independiente será preciso identificar como base aspectual al menos una oposición entre unidades que desde el punto de vista funcional resulten equivalentes en cuanto al valor modal y al temporal. Si, contrariamente, se comprueba que todas las posibles distinciones de índole aspectual tienen lugar siempre entre unidades que difieren también desde el punto de vista temporal, no habrá base rigurosa para justificar la adición de una nueva categoría a la explicación estructural del sistema.

Las opiniones de Alarcos Llorach y de Hernández Alonso, citadas por Rojo y Veiga (1999, p. 2919) señalan la concomitancia entre un determinado contenido aspectual y una determinada relación temporal, la de anterioridad; concomitancia que no permite considerar la significación aspectual como valor funcionalmente independiente con respecto a la referida relación temporal.

Pero es en lo referente a la oposición gramatical expresada por canté/ cantaba donde más voces se han alzado - y se alzan- para reclamar la existencia de una distinción funcionalmente aspectual.

Dos importantes observaciones:

a. No existe identidad de contenido temporal entre canté y cantaba, como demuestra la adecuada interpretación de los significados temporales como conjuntos de orientaciones relativas. La presencia en el significado de cantaba de un vector primario de simultaneidad, ausente en el de canté, es fácilmente comprobable mediante las transformaciones de tipo: "Dijo: Llueve" $\rightarrow$ "Dijo que llovía”, esto es, OoV $\rightarrow$ (OoV) oV, evidencia de una característica común, el vector primario, a los significados temporales de canto y cantaba. ${ }^{18}$ La presencia, por otra parte, en el significado de canté de un vector primario de anterioridad, ausente en el de cantaba, se comprueba

18 Coseriu $(1976,1980)$ considera que canté y cantaba pertenecen a dos planos temporales distintos, expresando cantaba en el plano inactual la misma perspectiva respectiva que expresa canto en el actual. 
fácilmente observando transformaciones de tipo: "Dijo: Llovió" $\rightarrow$ "Dijo que había llovido", esto es $\mathrm{O}-\mathrm{V} \rightarrow(\mathrm{O}-\mathrm{V})-\mathrm{V})$, donde se pone de manifiesto la existencia de una característica común, de nuevo el vector primario, a los significados temporales de canté y había cantado.

b. No existe una oposición directa en la estructura del sistema temporal entre las unidades expresadas por las formas canté y cantaba, como quieren las teorías que equiparan temporalmente dichas unidades. Una oposición directa entre unidades mínimas resulta, por definición, neutralizable sin que el resto de las oposiciones del sistema tenga que verse afectado (por ejemplo, lo que sucede con las oposiciones /p-b/ en el sistema fonológico español); ahora bien, la unidad con la que "cantaba” establece una relación opositiva de este tipo en el indicativo 0 español no es la expresada por "canté", sino la expresada por "cantaría”, pues la oposición de posterioridad funcional entre "cantaba/cantaría" se neutraliza en el contexto sintáctico de las prótasis condicionales con si. En esta situación la diferenciación respecto a canté sigue vigente: Si tu primo estaba en casa.../ Si tu primo estuvo en casa..., pero Si tu primo más tarde *estaría en casa...

No hay, por tanto, ni coincidencia temporal ni oposición directa entre los significados gramaticales expresados por canté y cantaba en español, lo que no permite la oposición funcional de base aspectual en este caso. Concuerdan Rojo y Veiga con Coseriu cuando este último expone que los diversos matices aspectuales señalables en las formas del tipo canté/ cantaba en las lenguas romances son efectos secundarios de las distinciones temporales.

Para Rojo y Veiga, no existe una base suficientemente sólida para individualizar la categoría gramatical de aspecto en cuanto a la categoría temporal en el núcleo del sistema verbal español, sin perjuicio de que podamos reconocer valores aspectuales en otros puntos de la gramática o en unidades léxicas de esta lengua.

\section{La Nueva gramática de la lengua española}

La Nueva gramática de la lengua española (2009) es una obra colectiva y colegiada entre las diversas academias de la lengua española que "pretende conjugar tradición y novedad", lo cual puede apreciarse cuando aborda el polémico tema de la temporalidad verbal.

Esta obra al trabajar la temporalidad verbal define que la flexión de tiempo constituye una información deíctica en el sentido en que vincula la referencia de las expresiones con la situación en que se halla quien las usa. Se dice que la flexión verbal expresa en español número y persona (que constituyen informaciones relativas al sujeto), modo y también tiempo y aspecto. Se reitera que el tiempo es una categoría deíctica $y$, por tanto, referencial. Se puntualiza que las informaciones temporales permiten localizar directa o indirectamente- los acontecimientos en relación con el momento cuando se habla.

Según esta obra, el tiempo gramatical orienta los eventos respecto al momento de la enunciación, pero también puede orientarlos en relación con otros puntos que, a su vez, se miden desde aquel. Además, de este hecho se deduce la mayor parte de los significados que el tiempo verbal expresa en la gramática española, pero hay oraciones que deben ser inscritas en cierto dominio temporal para poder ser interpretadas de manera cabal, y que la identificación de las expresiones referenciales y de los tiempos con las que aquellas se relacionan debe ser llevada a cabo supliendo informaciones que el contexto sintáctico o la situación del habla no proporcionan de manera inmediata, pero que el análisis gramatical debe dilucidar.

Asimismo, la nueva gramática define los tiempos verbales como las formas de la conjugación 
que gramaticalizan las informaciones temporales. Cada tiempo verbal (presente, futuro, etc.) constituye, por consiguiente, un paradigma flexivo que presenta las variantes de número y persona correspondientes a cada una de las relaciones que pueden darse entre los eventos. Estas relaciones son las de coincidencia o simultaneidad, anterioridad y posterioridad, pero se añaden a ellas otras algo más complejas, formadas a partir de estas: "el punto o momento del habla (también de la enunciación) es el que más claramente pone de manifiesto la naturaleza deíctica del tiempo verbal. Este punto coincide casi siempre con la situación en que se codifica el mensaje" (Nueva gramática de la lengua española, 2009, s. p.). No obstante, precisa que en ciertos casos el momento cuando se habla y aquel cuando se enuncia el mensaje no coinciden, por lo que se hace necesario distinguirlos. Cuando los actos de la codificación y descodificación no son simultáneos, el emisor ha de elegir entre uno de los dos para anclar las relaciones temporales. Ejemplifica con la correspondencia escrita, en la que el acto de codificación y la descodificación no son coincidentes y como consecuencia de esta distancia temporal, ciertos eventos que son simultáneos en el momento de la emisión resultan ser pasados respecto al de la descodificación:

\section{[...] lo habitual en la correspondencia escrita es que el emisor tome como origen o punto de anclaje (también llamado punto cero) el momento de la redacción de la carta y no el de su lectura. Pero en ocasiones se toma como referencia el momento de la descodi- ficación el mensaje. (2009, p. 1682)}

Hoy se entiende, según la Nueva gramática de la lengua española (2009), que el presente histórico constituya un caso particular de no coincidencia entre el momento de la enunciación y el punto del habla, es decir, el resultado de desplazar el punto de habla a un momento del pasado. Asimismo, que a pesar de que no todos los tiempos verbales se orientan directamente respecto al momento del habla, esta propiedad, manifestación directa de su naturaleza referencial, caracteriza a muchos de ellos.

Para la Nueva gramática de la lengua española las nociones de "anterioridad", "posterioridad" y "simultaneidad" ponen de manifiesto la naturaleza relacional del tiempo lingüístico y los conceptos puramente físicos "pasado", "futuro" y "presente" tienen, por tanto, cierto correlato gramatical; la sintaxis y el léxico muestran esas relaciones en gran número de formas lingüísticas. Resalta que la gramática de los tiempos, y las interpretaciones que adquieren, se deduce del anclaje de las formas verbales, es decir, de la vinculación que estas deben establecer con puntos temporales diversos. De igual forma, explica que el tiempo se manifiesta en el verbo, pero también en ciertos grupos adverbiales, preposiciones y grupos nominales, a los que llama adjuntos de tiempo, que contribuyen a localizar con mayor o menor precisión los eventos o a medir su extensión temporal.

Los adjuntos de tiempo comparten con las informaciones flexivas la propiedad de orientarse en función de puntos de referencia diversos. Se hace notar que la información semántica aportada por los adjuntos temporales ha de ser compatible con la que expresa la flexión verbal. Esta compatibilidad está condicionada por diversos factores gramaticales y está sujeta, además, a cierta variación dialectal.

La Nueva gramática de la lengua española recoge las clasificaciones de los tiempos verbales según varios criterios:

1. Su estructura morfológica.

2. Su anclaje temporal.

3. Sus características aspectuales. 
1. Por su estructura morfológica se dividen en simples y compuestos. Se explica la evolución de la antigua perífrasis latina con significado resultativo hasta la significación de los tiempos compuestos. Se analiza la relativa independencia sintáctica de los componentes de los tiempos verbales compuestos y se fundamenta por qué son considerados tiempos compuestos y no perífrasis verbales.

2. Por su anclaje temporal se dividen en absolutos y relativos (que da lugar a otra clasificación, algo más compleja, que se basa en la noción de 'esfera temporal'.) Según la Nueva gramática de la lengua española (2009), la clasificación en absolutos y relativos es polémica:

Los tiempos absolutos se orientan directamente respecto al momento de la enunciación. La distinción entre absolutos y relativos coincide solo en parte con la clasificación en simples y compuestos. En efecto, cantaba es un tiempo simple, pero también es relativo (salvo para los autores que le niegan el valor de copretérito), ya que se interpreta generalmente en relación con otro pretérito. Lo mismo cabe decir de cantaría (tiempo simple, pero relativo). Al contrario he cantado es un tiempo compuesto, pero se considera absoluto, ya que está anclado en el momento del habla. En los demás casos, la división simple/compuesto coincide con la clasificación absoluto/relativo. (p. 1678)

Esta obra aclara que se defiende en algunos estudios tradicionales la idea de que los tiempos absolutos se pueden emplear también como relativos, pero que los relativos no se pueden emplear como absolutos, y que esta posición es rechazada en la presente gramática. Advierte que "los tiempos verbales absolutos no pasan a ser relativos cuando forman parte de secuencias en las que se ordenan diversos sucesos, lo que obligaría a introducir un gran número de variables en su definición" (2009. p. 1679). Algunos estudiosos opinan lo contrario, porque ciertos desplazamientos en el eje deíctico constituyen argumentos de mayor peso a favor de considerar relativos algunos usos de los tiempos absolutos. Estos desplazamientos permiten que el momento del habla se retrotraiga, de forma que los tiempos que se miden en relación con el que experimenta esta traslación ajustan sus relaciones de concordancia, como sucede en el presente histórico: cuando Colón sale de Palos de la Frontera, los Reyes Católicos aún no han tomado Granada.

La Nueva gramática de la lengua española recoge en la tabla 14 las diversas denominaciones de los tiempos verbales.

Tabla 14

Denominaciones de los tiempos verbales

\begin{tabular}{|c|c|c|c|c|c|c|}
\hline \multicolumn{3}{|c|}{ FORMA VERBAL } & Bello (1847) & RAE [1931] & Esbozo (1973) & DRAE/DPD \\
\hline \multirow{5}{*}{$\begin{array}{l}\text { 足 } \\
\text { 壳 } \\
\text { 号 } \\
\text { 品 } \\
\text { 号 }\end{array}$} & \multirow{5}{*}{ 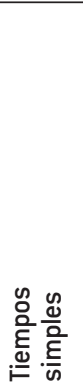 } & CANTO & presente & presente & presente & presente \\
\hline & & CANTÉ & pretérito & $\begin{array}{l}\text { pretérito } \\
\text { indefinido }\end{array}$ & $\begin{array}{l}\text { pretérito } \\
\text { perfecto } \\
\text { simple }\end{array}$ & $\begin{array}{l}\text { pretérito } \\
\text { perfecto } \\
\text { simple }\end{array}$ \\
\hline & & CANTABA & copretérito & $\begin{array}{l}\text { pretérito' } \\
\text { imperfecto }\end{array}$ & $\begin{array}{l}\text { pretérito } \\
\text { imperfecto }\end{array}$ & pretérito imperfecto \\
\hline & & CANTARÉ & futuro & $\begin{array}{l}\text { futuro } \\
\text { simple }\end{array}$ & futuro & $\begin{array}{l}\text { futuro } \\
\text { simple }\end{array}$ \\
\hline & & CANTARÍA & pospretérito & $\begin{array}{l}\text { potencial } \\
\text { simple }\end{array}$ & condicional & condicional simple \\
\hline
\end{tabular}




\begin{tabular}{|c|c|c|c|c|c|c|}
\hline \multirow{5}{*}{ 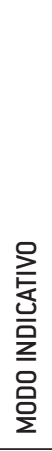 } & \multirow{5}{*}{ 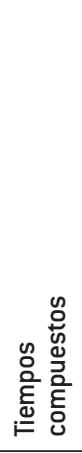 } & HE CANTADO & antepresente & $\begin{array}{l}\text { pretérito } \\
\text { perfecto }\end{array}$ & $\begin{array}{l}\text { pretérito } \\
\text { perfecto } \\
\text { compuesto }\end{array}$ & $\begin{array}{l}\text { pretérito } \\
\text { perfecto compuesto }\end{array}$ \\
\hline & & HABÍA CANTADO & antecopretérito & $\begin{array}{l}\text { pretérito } \\
\text { pluscuam- } \\
\text { perfecto }\end{array}$ & $\begin{array}{l}\text { pretérito } \\
\text { pluscuam- } \\
\text { perfecto }\end{array}$ & $\begin{array}{l}\text { pretérito pluscuam- } \\
\text { perfecto }\end{array}$ \\
\hline & & HABRÉ CANTADO & antefuturo & $\begin{array}{l}\text { futuro } \\
\text { compuesto }\end{array}$ & $\begin{array}{l}\text { futuro } \\
\text { perfecto }\end{array}$ & $\begin{array}{l}\text { Futuro } \\
\text { compuesto }\end{array}$ \\
\hline & & HABRÍA CANTADO & antepospretérito & $\begin{array}{l}\text { potencial } \\
\text { compuesto }\end{array}$ & $\begin{array}{l}\text { condiciona } \\
\text { perfecto }\end{array}$ & condicional compuesto \\
\hline & & HUBE CANTADO & antepretérito & $\begin{array}{l}\text { pretérito } \\
\text { anterior }\end{array}$ & $\begin{array}{l}\text { pretérito } \\
\text { anterior }\end{array}$ & $\begin{array}{l}\text { pretérito } \\
\text { anterior }\end{array}$ \\
\hline \multirow{6}{*}{ 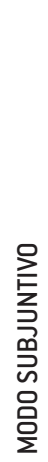 } & \multirow{3}{*}{ 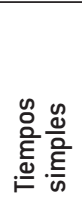 } & CANTE & presente & presente & presente & presente \\
\hline & & $\begin{array}{l}\text { CANTARA } 0 \\
\text { CANTASE }\end{array}$ & pretérito & $\begin{array}{l}\text { pretérito } \\
\text { imperfecto }\end{array}$ & $\begin{array}{l}\text { pretérito } \\
\text { imperfecto }\end{array}$ & pretérito imperfecto \\
\hline & & CANTARE & futuro & $\begin{array}{l}\text { futuro } \\
\text { simple }\end{array}$ & futuro & $\begin{array}{l}\text { Futuro } \\
\text { simple }\end{array}$ \\
\hline & \multirow{3}{*}{ 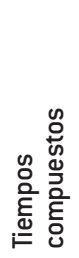 } & HAYA CANTADO & antepresente & $\begin{array}{l}\text { pretérito } \\
\text { perfecto }\end{array}$ & $\begin{array}{l}\text { pretérito } \\
\text { perfecto }\end{array}$ & $\begin{array}{l}\text { pretérito } \\
\text { perfecto compuesto }\end{array}$ \\
\hline & & $\begin{array}{l}\text { HUBIERA O HUBIESE } \\
\text { CANTADO }\end{array}$ & antecopretérito & $\begin{array}{l}\text { pretérito } \\
\text { pluscuam- } \\
\text { perfecto }\end{array}$ & $\begin{array}{l}\text { pretérito } \\
\text { pluscuam- } \\
\text { perfecto }\end{array}$ & $\begin{array}{l}\text { pretérito pluscuam- } \\
\text { perfecto }\end{array}$ \\
\hline & & HUBIERE CANTADO & antefuturo & $\begin{array}{l}\text { futuro } \\
\text { compuesto }\end{array}$ & $\begin{array}{l}\text { futuro } \\
\text { prefecto }\end{array}$ & $\begin{array}{l}\text { futuro } \\
\text { compuesto }\end{array}$ \\
\hline
\end{tabular}

Nota. Tomado de Real Academia Española (2009).

En la Nueva gramática de la lengua española (2009) se reflexiona acerca de los problemas terminológicos, se hace un comentario relacionado con la nomenclatura de Bello, que es la utilizada en Cuba, pero finalmente se adopta la terminología de obras académicas recientes. Para el autor de este trabajo, la nomenclatura más apropiada, por ser la que más se acerca a lo que expresan los tiempos verbales, es la de Bello.

Por sus características aspectuales se distinguen tiempos perfectos e imperfectos. Sobre el aspecto verbal, la Nueva gramática de la lengua española explica que este informa sobre la estructura interna de los sucesos: si surgen, se terminan o se repiten, si se perciben en su integridad o se muestran únicamente en un punto de su desarrollo. El aspecto verbal no afecta a su vínculo (directo o indirecto) con el momento del habla, sino al tiempo interno de la situación. En razón de esta propiedad, se ha descrito también como un recurso gramatical que permite enfocar o focalizar ciertos componentes de las situaciones, a la vez que ocultar u omitir otros.

La Nueva Gramática reconoce que la cuestión es en qué medida la categoría de aspecto está presente en la lengua española. El aspecto verbal, atendiendo a la forma como se manifiesta, se divide en tres grupos: aspecto léxico o modo de acción, aspecto sintáctico o perifrástico y aspecto morfológico o desinencial.

El aspecto léxico recibe también las denominaciones de modo de acción, cualidad de la acción y accionalidad, y se obtiene de la significación del predicado. El aspecto sintáctico o perifrástico corresponde a las perífrasis verbales, sobre todo a las llamadas de fase o fasales, aunque también a las tempoaspectuales, las escalares y las de gerundio.

El aspecto morfológico se expresa a través de las desinencias verbales. Según este, la tradición 
gramatical divide los tiempos en perfectos e imperfectos aunque en la actualidad es más frecuente hablar de tiempos perfectivos y tiempos imperfectivos. El aspecto perfectivo (también aoristo para algunos autores) focaliza las situaciones en su conjunto, de principio a fin, y las presenta como completas o acabadas. Se exceptúa la variedad denominada incoativa o ingresiva, que focaliza solo el inicio de la situación.

Además del aspecto imperfectivo y el perfectivo, algunos autores reconocen el llamado aspecto perfecto, que otros consideran una variedad del perfectivo. Este alude a cierto estado de cosas que resulta de un proceso previo.

Pérez Saldanya (2004), por su parte, tiene otro punto de vista. Distingue la categoría gramatical de aspecto en relación con una categoría de base fundamentalmente léxica (Aktionsart o aspecto léxico). La modalidad de la acción, de hecho, no es una categoría de visualización, una categoría subjetiva, una categoría que permita presentar una misma situación de maneras diferentes, sino una categoría objetiva, referida a la naturaleza misma de la situación: a su carácter activo o estativo, al hecho de que pueda tener o no un punto final de culminación, a su carácter puntual o durativo. El autor añade que uno de los problemas del análisis tradicional del aspecto es que no establece una clara distinción entre las dos categorías: la categoría gramatical de carácter subjetivo y la objetiva y de naturaleza fundamentalmente léxica, que depende del significado del verbo y de otros factores como las propiedades sintácticas de los argumentos seleccionados por el verbo, la negación, las perífrasis modales, el tiempo cuando se conjuga el verbo, e incluso el tipo de discurso cuando inserta. La categoría gramatical no tiene una expresión formal independiente y aparece fusionada a las categorías de tiempo y modo, o expresada mediante perífrasis muy gramaticalizadas, como la construcción "haber + participio".

\section{Conclusiones}

Como se ha podido percibir, las teorías acerca de la temporalidad lingüística, desde la Gramática de Andrés Bello hasta la Nueva gramática de la lengua española (2009), han evolucionado y se han ido actualizando a tenor de los estudios lingüísticos predominantes en cada época. A través de su estudio se pueden señalar puntos que, con mayor o menor coincidencia, son comunes:

La diferenciación entre tiempo físico, que es exterior al hombre, y tiempo lingüístico, que se basa en el tiempo cronológico, pero no coincide totalmente con él. La característica fundamental del tiempo lingüístico y la única que funciona en muchas lenguas es la orientación directa o indirecta con respecto al momento del habla. La categoría de tiempo es deíctica, por tanto, referencial. Las informaciones temporales permiten localizar — directa o indirectamente- los acontecimientos en relación con el momento cuando se habla.

La existencia de un punto de origen, o momento del habla, o momento de la enunciación, a partir el cual se orientan los tiempos verbales. Hay tiempos verbales que no se orientan directamente en relación con el momento del habla, sino con otra referencia que a su vez está orientada respecto al momento del habla. En cuanto a la clasificación de tiempos absolutos y relativos, como reconoce la Nueva gramática de la lengua española (2009), es polémica: "Los tiempos absolutos se orientan directamente respecto al momento de la enunciación. La distinción entre absolutos y relativos coincide solo en parte con la clasificación en simples y compuestos" (p. 1685). Aclara la Nueva gramática de la lengua española que se defiende en algunos estudios tradicionales la idea de que los tiempos absolutos se pueden emplear también como relativos, mientras que los absolutos no se emplean como tal, posición que se rechaza en esta gramática. 
Los tiempos verbales expresan anterioridad, simultaneidad o posterioridad respecto al momento del habla o en relación con otra referencia.

Los tiempos verbales pueden expresar usos temporales básicos y usos modales derivados. Los usos básicos responden al valor paradigmático de los tiempos (el valor que presentan dentro del sistema de oposiciones temporales y aspectuales), y los usos derivados son traslaciones de estos valores motivados por el contexto sintagmático en el que aparecen los tiempos.

Aunque no hay total acuerdo acerca de la jerarquía de la categoría de aspecto en el sistema verbal del español, se coincide en la existencia de valores aspectuales, ya sea expresados por la semántica del verbo, los morfemas flexivos o por las perífrasis verbales, que tienen una estrecha relación con los valores temporales que portan. El aspecto no es una categoría deíctica, informa acerca de la estructura interna de los sucesos; posibilita saber si surgen, se terminan o se repiten, pero también si se perciben en su integridad o se muestran únicamente en un punto de su desarrollo. El aspecto verbal afecta, pues, al tiempo interno de la situación, y no a su vínculo (directo o indirecto), con el momento del habla. Se ha descrito también como un recurso gramatical que permite enfocar o focalizar ciertos componentes de las situaciones, a la vez que ocultar u omitir otros. En cuanto al aspecto, existen diversos criterios, algunos de los cuales llegan a cuestionar su existencia como categoría en el español. 


\section{Referencias}

Alarcos Llorach, E. (1994). Gramática de la lengua española. Madrid: Espasa-Calpe.

Alonso, A. (1995). Introducción a los estudios gramaticales. Recuperado de http://www.cervantesvirtual.com/ obra/gramatica-gramatica-de-la-lengua-castellana-destinada-al-uso-de-los-americanos--0/

Bello, A. (1981). Gramática de la lengua castellana. Tenerife: Instituto Universitario de Lingüística André Bello. Bosque Muñoz, I. (2002). Redes. Diccionario combinatorio del español contemporáneo. Madrid: Ediciones SM.

Bosque, I. y Demonte, V. (1999). Gramática descriptiva de la lengua española 2. Las construcciones sintácticas fundamentales. Relaciones temporales, aspectuales y modales. Real Academia Española Colección Nebrija y Bello. Madrid: Espasa-Calpe.

Comrie, B. (1976). Aspect: An Introduction to the Study of Verbal Aspect and Related Problems. Cambridge: Cambridge University Press.

Comrie, B. (1985). Tense. Cambridge: Cambridge University Press.

Coseriu, E. (1977). Principios de semántica estructural (2da. Ed). Madrid: Gredos.

Coseriu, E. (1996). El sistema verbal románico. Madrid: Siglo xxi.

Curbeira Cancela, A. (2003). Lecturas de semántica I. La Habana: Félix Varela.

Curbeira Cancela, A. (2013). Teorías lingüísticas: concepciones y corrientes. La Habana: Félix Varela.

Gili Gaya, S. (1974). Curso superior de sintaxis española. La Habana: Instituto Cubano del Libro.

Havu, J. (1998). La constitución temporal del sintagma verbal en el español moderno. (Tesis doctoral). Gummerus Kirjapaino Oy, Saarijärvi, Finlandia.

Jakobson, R. (1963). Les embrayeurs, les catégories verbales et le verbo russe. Essais de linguistique générale. Paris : Edition de Minuit.

Klein, W. (1994). Learning how to express temporality in a second language. En Congresso Società di linguistica Italiana, SLI 343. Italiano: lingua seconda/lingua straniera. Atti del XXVI. Roma: Bulzoni.

Lamíquiz, V. (1972). Morfosintaxis estructural del verbo español. Sevilla: Publicaciones de la Universidad de Sevilla. Lamíquiz, V. (1982). El sistema verbal del español. Málaga: Ágora.

López García, Á. (1990). La interpretación metalingüística de los tiempos, modos y aspectos del español: ensayo de fundamentación. En I. Bosque (Coord.), Tiempo y aspecto en español (pp. 107-176). Madrid: Cátedra.

López García, Á. (2004). Aportaciones de las ciencias cognitivas. En V., Lara castro (Coord.), Vademécum para la formación de profesores. Enseñar español como segunda lengua (L2)/lengua extranjera (LE). Madrid: Sociedad General Española de Librería, S.A.

López García, Á. (2005). Gramática cognitiva para profesores de español L2. Madrid: Arco Libros S.A.

Luquet, G. (2004). La teoría de los modos en la descripción del verbo español. Un nuevo planteamiento. Madrid: Arco Libros, S.A.

Lyons, J. (1980). Semántica. Barcelona: Editorial Teide.

Pérez Saldanya, M. (2004). Los tiempos verbales: dificultades teóricas y terminológicas. En L. García Fernández y B. Bamus Bergareche (Eds.), El pretérito imperfecto (pp. 194-227). Madrid: Gredos.

Pottier, B. (1964). Vers une sémantique moderne. Travaux de Linguistique et de Littérature, II(1), 107-137.

Pottier, B. (1970). Gramática del español. Madrid: Ediciones Alacalá.

Real Academia Española (RAE). (1931). Gramática de la lengua española. Madrid: Espasa-Calpe.

Real Academia Española (RAE) y Asociación de Academias de Lengua Española. (2005). Diccionario panhispánico de dudas. Santillana. Madrid: Ediciones Generales, S.A.

Real Academia Española (RAE). (2009). Nueva gramática de la lengua española. Morfología y sintaxis I. Madrid: Espasa Libros, SLU.

Real Academia Española (RAE). (2010). Nueva gramática de la lengua española. Manual. Madrid: Planeta. 
Reichenbach, Hans. (1947). Elements of symbolic logic. Nueva York: Free Press.

Rivas Zancarrón, M. (1998). Dimensiones de fase y visión en español y árabe. El problema de las categorías aspectuales. En Estudios de la Universidad de Cádiz ofrecidos a la memoria del profesor Braulio Justel Calabozo (pp. 273-282). Cádiz: Universidad de Cádiz.

Rivas Zancarrón, M. (2000). Apostillas críticas a la teoría del tiempo y el aspecto verbal. En W. E. Bull y K. Heger. Documentos del español actual. (Volumen 2). Finlandia: Universidad de Turku.

Rojo, G. (1974). La temporalidad verbal en español. Verba: anuario gallego de filología, (1), 68-149.

Rojo, G. (1990). Relaciones entre temporalidad y aspecto en el verbo español. En I. Bosque (Coord.), Tiempo y aspecto en español (17-44). Madrid: Cátedra.

Rojo, G. y Veiga, A. (1999). El tiempo verbal. Los tiempos simples. En I. Bosque y V. Demonte (Coords.), Gramática descriptiva de la lengua española 2. Las construcciones sintácticas fundamentales. Relaciones temporales, aspectuales y modales (pp. 2867-2934. Madrid: Real Academia Española Colección Nebrija y Bello.

Van Dijk, J. (1992). La ciencia del texto. Barcelona: Paidós.

Veiga, A. (1999). La ordenación jerárquica de las oposiciones temporales en español. Verba: anuario gallego de filosofía, (26), 129-163. 


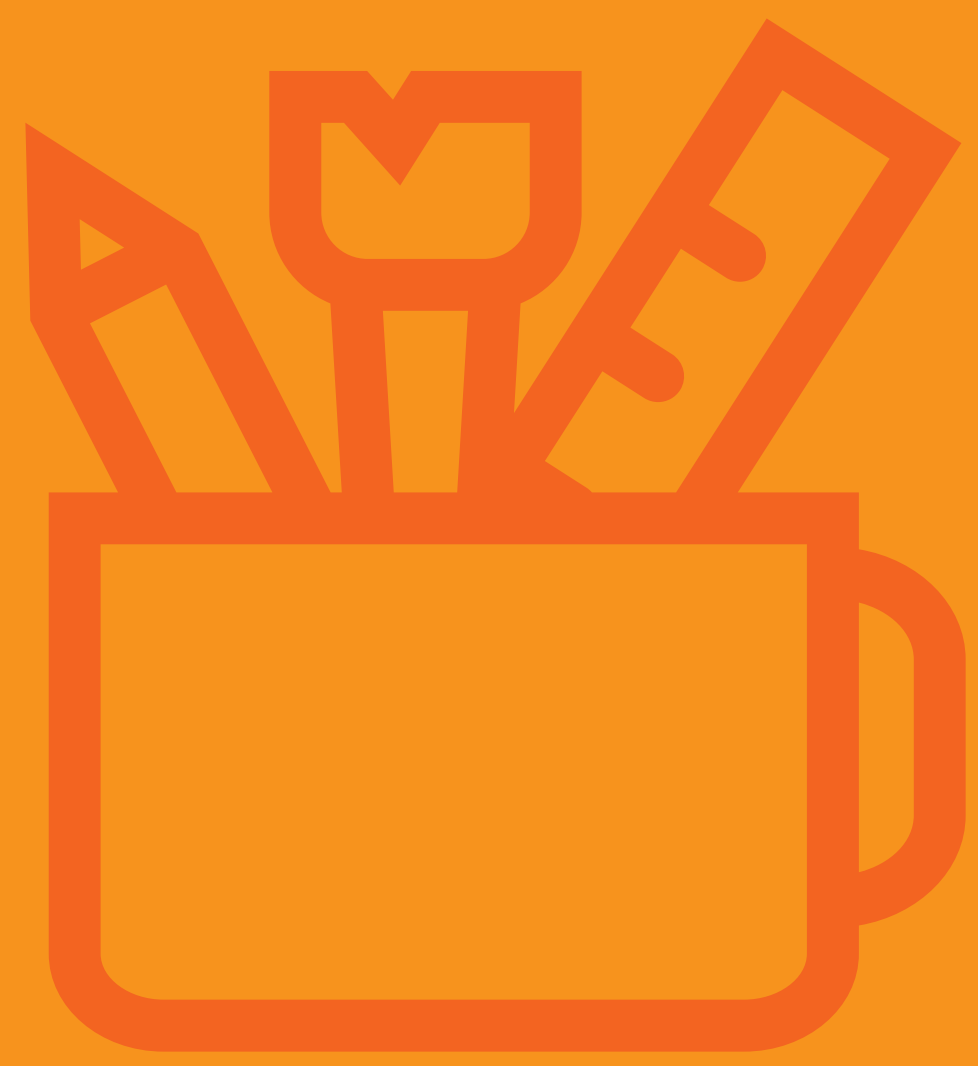

